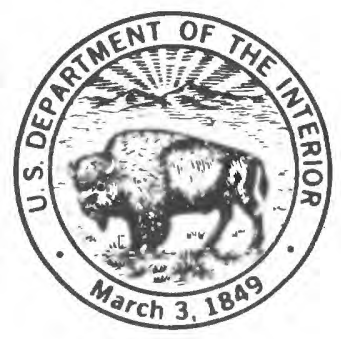

WATER QUALITY OF THE NEUSE RIVER, NORTH CAROLINA Variability, pollution loads, and long-term trends

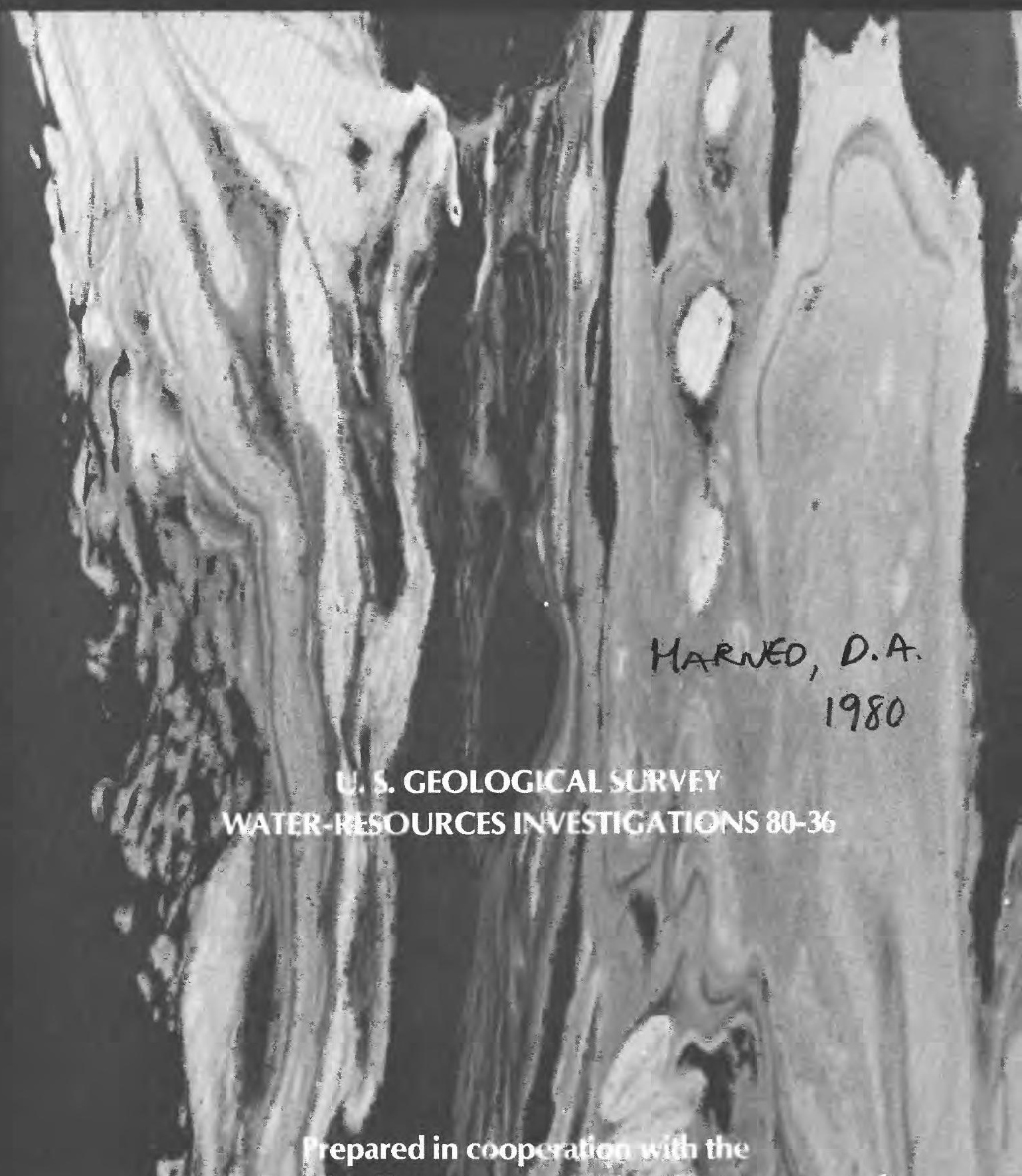

Wo $t$ Cir lina Department of Nílóral Resourcesand

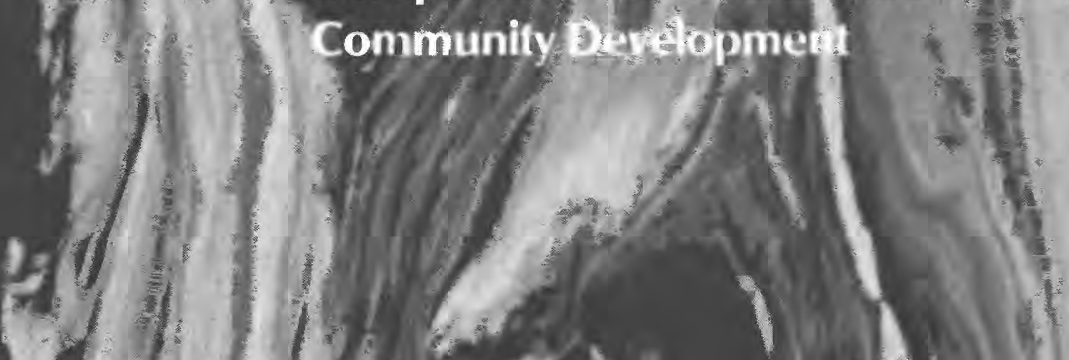


4. Title and Subtitle

WATER QUALITY OF THE NEUSE RIVER, NORTH CAROLINA--Variability, Pollution 1oads, and long-term trends

7. Author(s) Douglas A. Harned

9. Performing Organization Name and Address

U.S. Geological Survey

Water Resources Division

P. 0. Box 2857

Raleigh, N.C. 27602

2.

3. Recipient's Accession No.

Report Date

February 29, 1980

6.

8. Performing Organization Rept. No. USGS/WRI 80-36

10. Project/Task/Work Unit No.

11. Contract(C) or Grant(G) No.

(C)

(G)

13. Type of Report \& Period Covered

U.S. Geological Survey

Water Resources Division

P. 0. Box 2857

Raleigh, N.C. 27602

14.

15. Supplementary Notes

Prepared in cooperation with the North Carolina Department of Natural Resources and Community Development

16. Abstract (Limit: 200 words) A water-quality study of the Neuse River, based on data collected during 1956-77 at the U.S. Geological Survey stations at Clayton and Kinston, employs statistical trend analysis techniques that provide a framework for river-quality assessment.

Overa11, water-quality of the Neuse River is satisfactory for most uses. At Clayton, fecal coliform bacteria and nutrient levels are high, but algae and TOC data indicate water-quality improvement in recent years, due probably to a new wastewater treatment plant located downstream from Raleigh, N.C.

Pollution was determined by subtracting estimated natural loads of constituents from measured total loads. Pollution makes up approximately 50 percent of the total dissolved material transported by the Neuse.

Two different data transformation methods allowed trends to be identified in constituent concentrations. The methods permit recomputation of concentrations as if they were determined at a constant discharge over the period of record. Although little change since 1956 can be seen in most constituents, large changes in some constituents, such as increases in potassium and sulfate, indicate that the water quality of the Neuse River has noticeably deteriorated. Increases in sulfate are probably largely due to increased longterm inputs of sulfur compounds from acid precipitation.

17. Document Analysis a. Descriptors

*Water quality, *water pollution, *river basin, *statistical analysis, *time series analysis, dissolved solids, specific conductance, trace elements, nutrients, dissolved oxygen, coliforms, phytoplankton, regression analysis, frequency analysis, *Neuse River, North Carolina, Watex pollution effects, trends, acid rain.

b. Identifiers/Open-Ended Terms

Piedmont, Coastal Plain.

c. COSATI Field/Group

18. Availability Statement

No restriction on distribution

\begin{tabular}{|l|} 
19. Security Class (This Report) \\
UNCLASSIFIED \\
\hline 20. Security Class (This Page) \\
UNCLASSIFIED
\end{tabular}

21. No. of Pages 88

22. Price 


\title{
WATER QUALITY OF THE NEUSE RIVER, NORTH CAROLINA Variability, pollution loads, and long-term trends
}

\author{
By \\ Douglas A. Harned
}

\section{U. S. GEOLOGICAL SURVEY \\ WATER-RESOURCES INVESTIGATIONS 80-36}

\begin{abstract}
Prepared in cooperation with the
North Carolina Department of Natural Resources and

Community Development
\end{abstract}




\section{UNITED STATES \\ DEPARTMENT OF THE INTERIOR \\ CECIL D. ANDRUS, Secretary}

GEOLOGICAL SURVEY

H. W. Menard, Director

For Additional Information Write to:

U.S. Geological Survey

Post Office Box 2857

Raleigh, North Carolina 27602

February 29, 1980 


\section{CONTENTS}

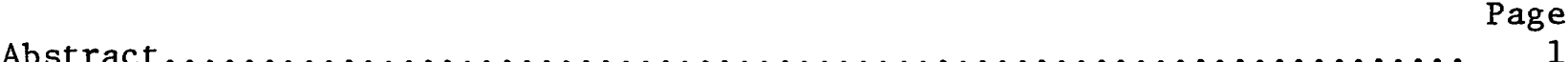

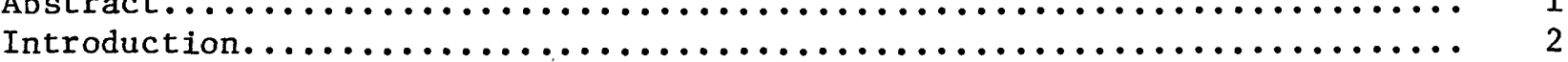

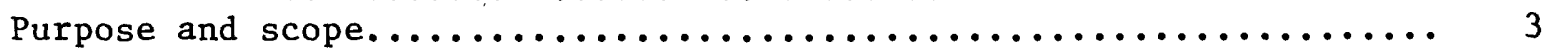

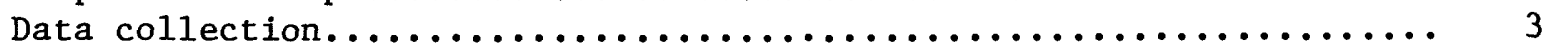

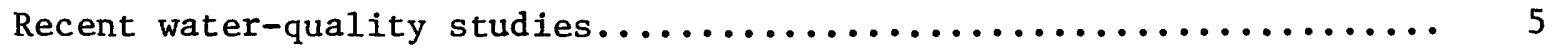

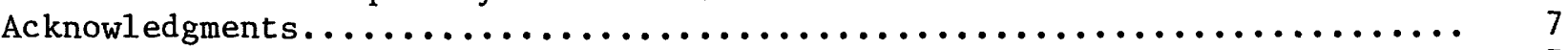

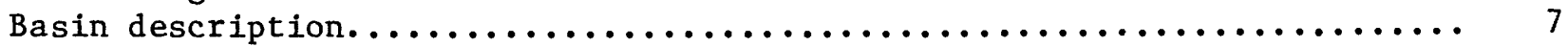

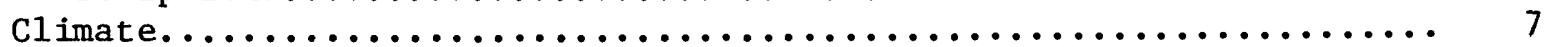

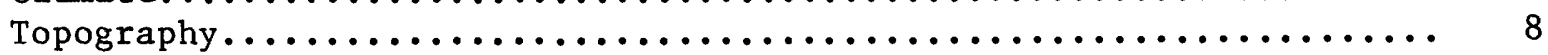

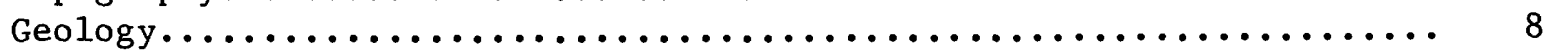

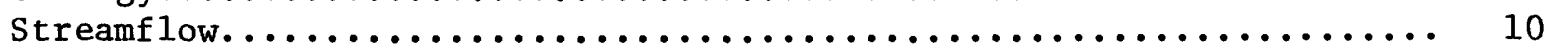

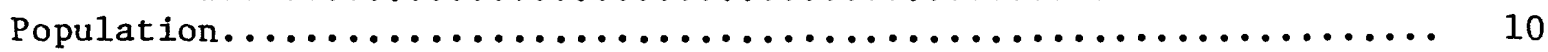

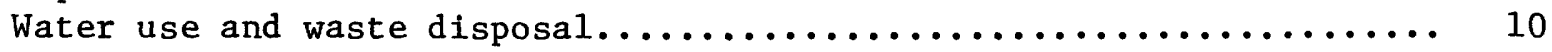

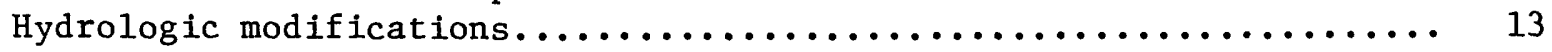

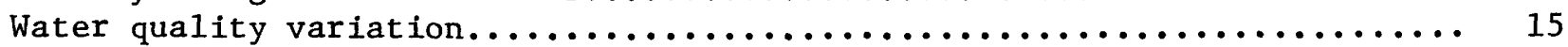

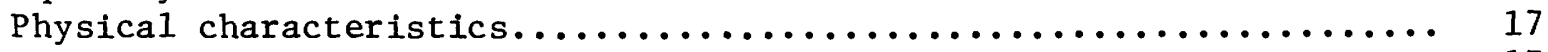

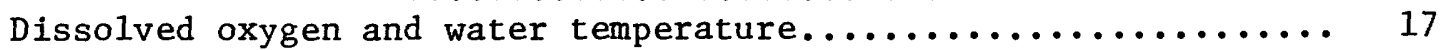

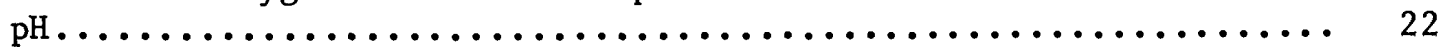

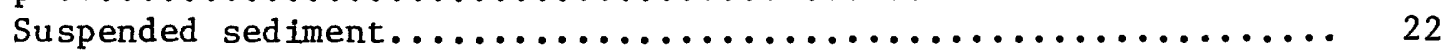

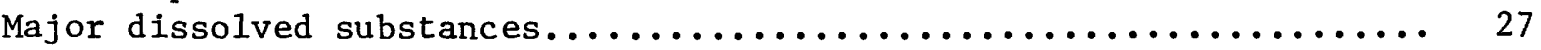

Trace elements...................................... 30

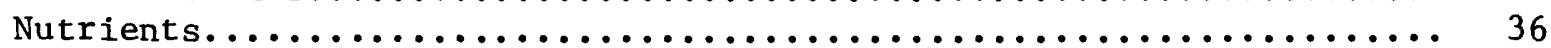

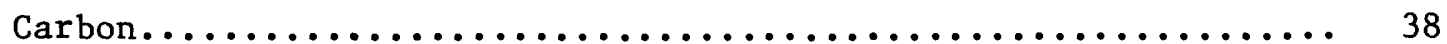

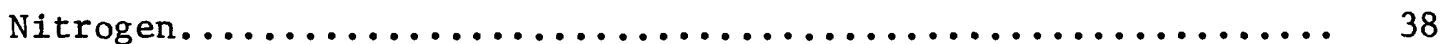

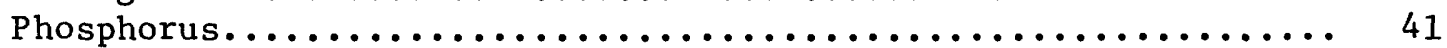

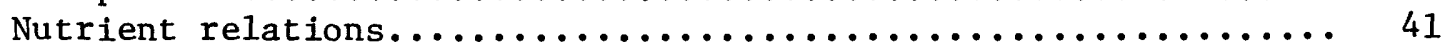

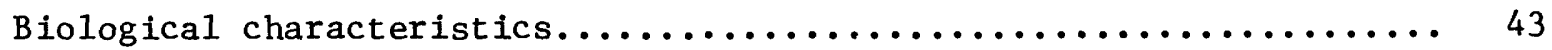

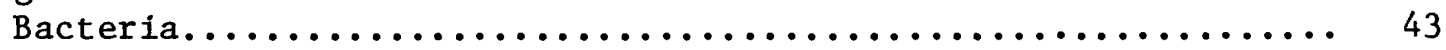

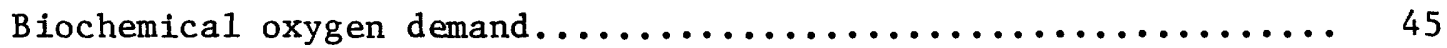

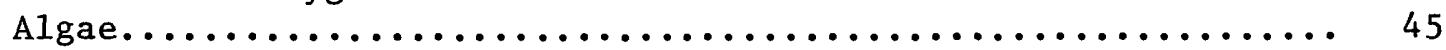

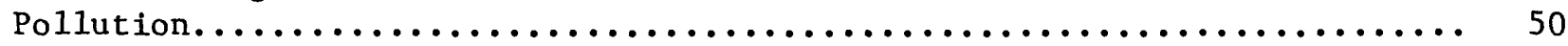

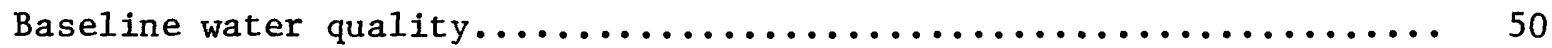

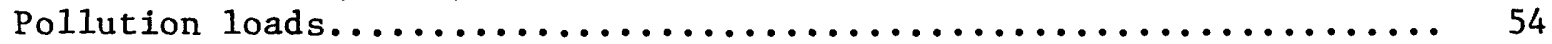

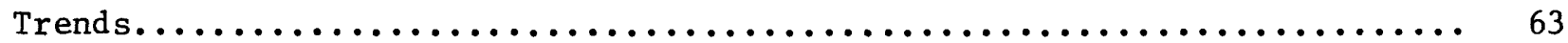

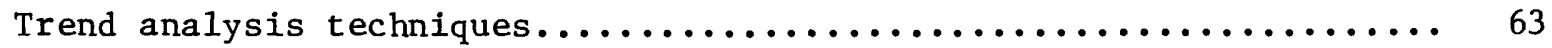

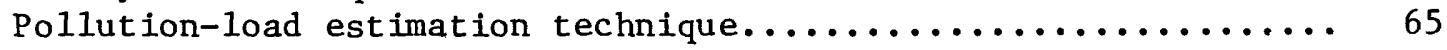

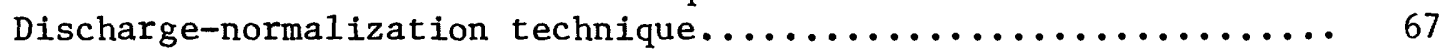

Discharge-frequency-weighting technique............... 70

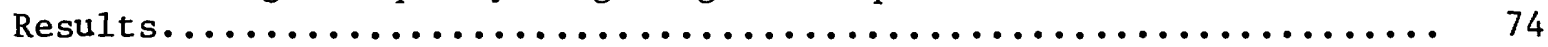

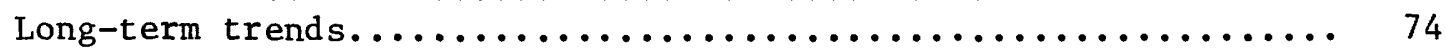

Water quality - population relations.................. 80

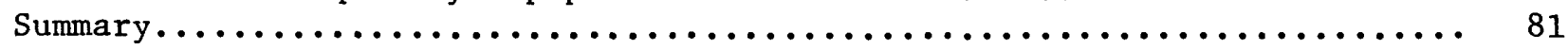

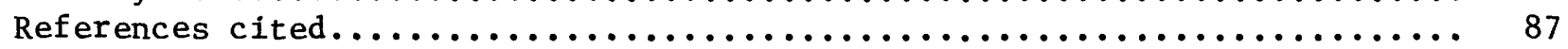




\section{ILLUSTRATIONS}

Figure 1. Map showing locations of water-quality sampling stations

Page

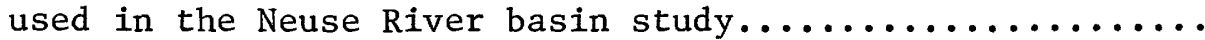

2. Graph showing period of record for water-quality sample collection, and discharge measurement at stations used in the

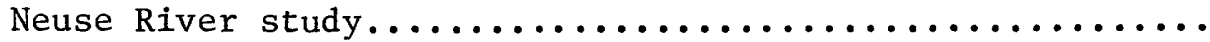

3. Map showing geochemical zones of the Neuse River basin........

4. Map showing percentage of total Neuse River basin population

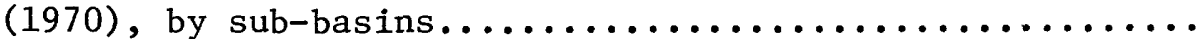

5. Map showing percentage of total municipal and industrial wastewater discharges for the Neuse River basin, by sub-

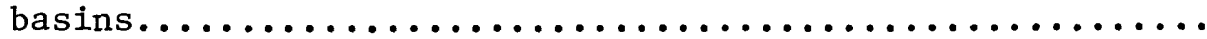

6. Plot of air and water temperatures, $1976 \ldots \ldots \ldots \ldots \ldots \ldots \ldots \ldots$

7. Plot of dissolved-oxygen concentrations versus water temperatures for the Neuse River at Clayton.................

8. Plot of dissolved-oxygen concentrations versus water temperatures for the Neuse River at Kinston................

9. Hydrograph showing relationship of discharge and suspendedsediment concentration for the storm of August 4, 1974, at

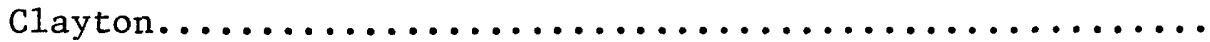

10. Plot of stream discharge versus suspended-sediment concentration for 1973-76, Neuse River at Clayton.............

11. Plot of stream discharge versus suspended-sediment concentration for 1973-76, Neuse River at Kinston............

12. Cation-anion diagrams for the Neuse River at Clayton and

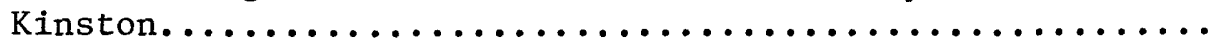

13. Frequency distribution of daily specific conductance values,

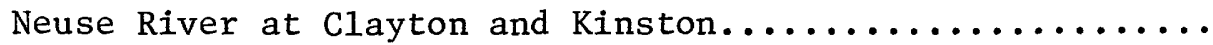

14. Graph showing regression lines of dissolved-constituent concentration versus the known range of specific conductance,

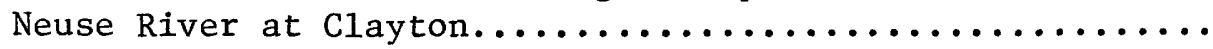

15. Graph showing regression lines of dissolved-constituent concentration versus the known range of specific conductance,

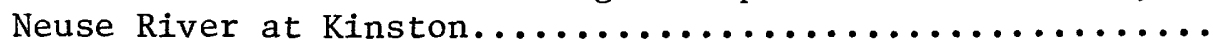

16. Plot showing relation of discharge and dissolved-solids concentration of the Neuse River at Clayton, 1956-67

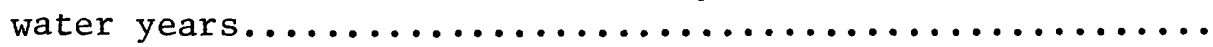

17. Frequency histograms for total nitrite plus nitrate (as $N$ ) of

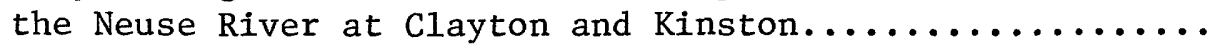

18. Frequency histograms for total nitrogen (as $N$ ) of the Neuse

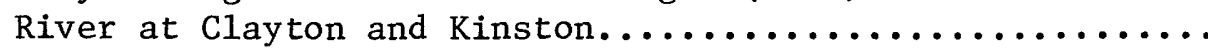

19. Frequency histograms for total phosphorus (as P) of the Neuse

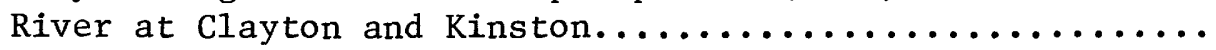

20. Hydrograph of discharge, total nitrogen and total phosphorus concentration for the storm of August 4, 1974, Neuse River

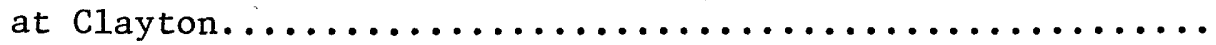

21. Plot of algal cell counts and discharge for the Neuse River at

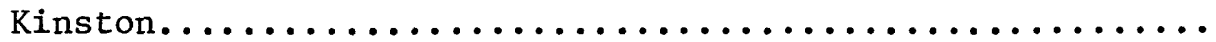


Figure 22. Comparisons of baseline water quality and observed water

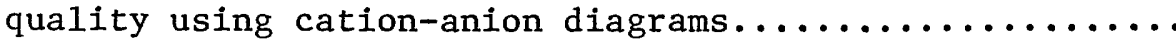

23. Plot showing dissolved-solids load for the Neuse River at

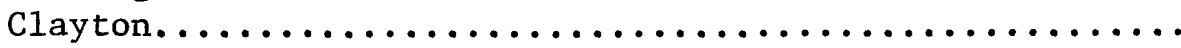

24. Plot showing dissolved-solids load for the Neuse River at

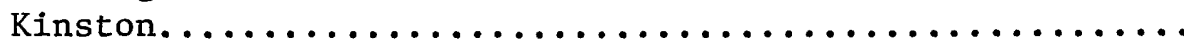

25. Plot showing percentage of total dissolved-solids load from pollution for the Neuse River at Clayton and Kinston, and

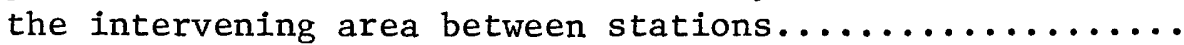

26. Graph of potassium pollution loads, with regression lines for

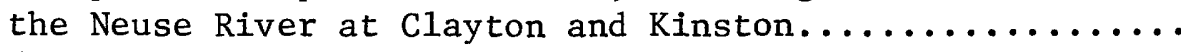

27. Flow-diagram of the discharge-normalization technique........

28. Graph of normalized potassium concentrations, with regression lines for the Neuse River at Clayton and Kinston.........

29. Graphic comparison of normalized and nonnormalized annual dissolved-solids loads for the Neuse River at Kinston....

30. Flow-diagram of the discharge-frequency-weighting technique

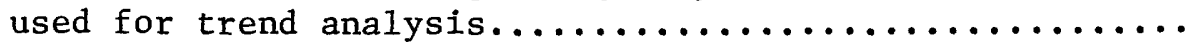

31. Graph of weighted potassium concentrations, with regression lines, for the Neuse River at Clayton and Kinston.......

32. Graph of weighted and normalized dissolved-solids concentrations, with regression Iines, for the Neuse River at

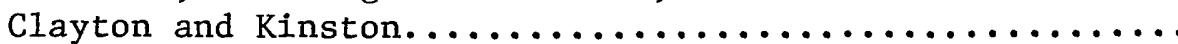

33. Graph of weighted and normalized sulfate concentrations, with regression lines, for the Neuse River at Clayton and

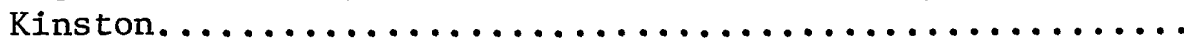

34. Normalized dissolved-solids concentration for the Neuse River at Kinston plotted against the manufacturing employment-population index for the river basin upstream

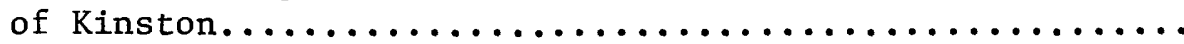

\section{TABLES}

Table 1. Major municipal and industrial wastewater discharges of the Neuse River basin (from North Carolina Department of

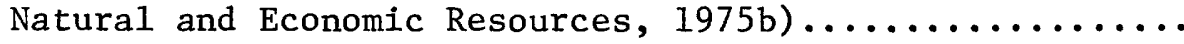

2. Summary statistics of physical characteristics, Neuse River

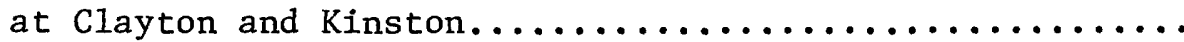

3. A summary of statistics for major dissolved substances for samples collected from the Neuse River at Clayton and

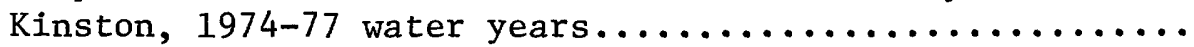

4. A summary of total trace-element concentration statistics for the Neuse River at Clayton and Kinston, 1974-77

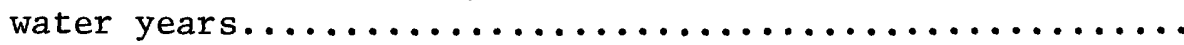

5. A summary of nutrient statistics for samples of the Neuse River at Clayton and Kinston, 1974-77 water years....... 
Table 6. Summary statistics for biological analyses, Neuse River at

7. Major algal division dominance, represented by the percent of time over the water year,in which each division is domi-

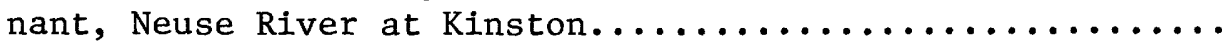

8. Comparison of water quality of samples from the Neuse River at Clayton with samples from baseline water-quality sites in

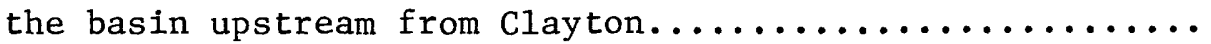

9. Comparison of water quality of samples from the Neuse River at Kinston with samples from baseline water-quality sites in

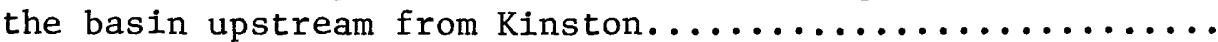

10. Dissolved-solids loads and concentrations for the Neuse River at

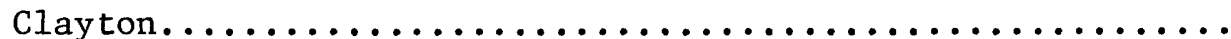

11. Dissolved-solids loads and concentrations for the Neuse River at

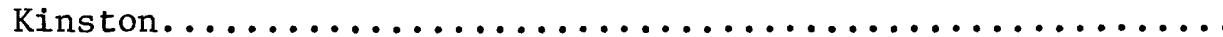

12. A comparison between total, baseline, and pollution dissolvedsolids loads on a tons per square mile per year basis......

13. Average loads of sodium, chloride, and sulfate transported by the Neuse River at Clayton and Kinston, 1974-77

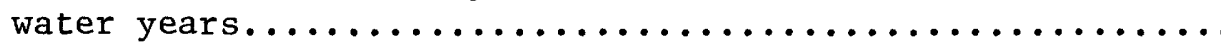

14. Regression equations for results of the pollution load method, discharge-normalization technique, and the discharge-

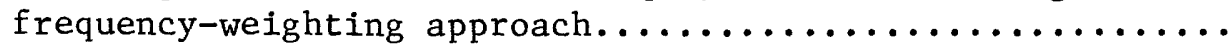

15. Regression equations for relations between chemical or physical constituents and the manufacturing employment-population index for the Neuse River at Clayton and Kinston..........

COVER PHOTO: Foam floating on water surface. 


\section{INTERNATIONAL SYSTEM UNITS}

The following factors may be used to convert inch-pound units published herein to the International System of Units (SI).

Multiply inch-pound unit

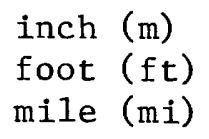

acre

square mile $\left(\mathrm{mi}^{2}\right)$

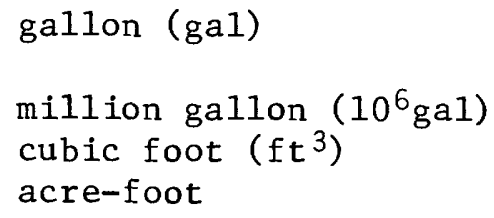

degree Fahrenheit $\left({ }^{\circ} \mathrm{F}\right)$

ton (short, 2000 pounds)

cubic foot per second per square mile $\left(\mathrm{ft}^{3} / \mathrm{s}\right) / \mathrm{mi}$

\section{Flow}

By

\section{Length}

$$
\begin{aligned}
& 25.4 \\
& 0.3048 \\
& 1.609
\end{aligned}
$$

Area

$$
\begin{aligned}
& 4047 \\
& \quad 0.4047 \\
& 0.004047 \\
& 2.590
\end{aligned}
$$

\section{Volume}

$$
\begin{gathered}
3.785 \\
0.003785 \\
3785 \\
0.02832 \\
1233.5
\end{gathered}
$$

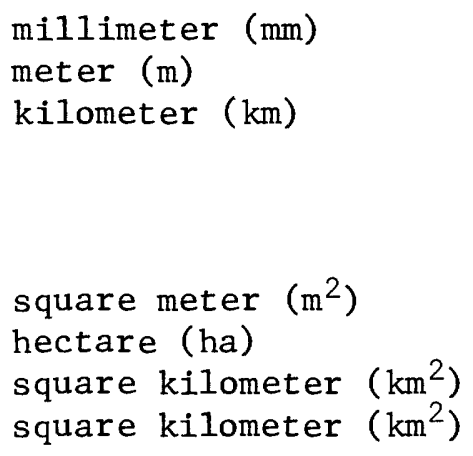

To obtain SI unit

$$
\begin{aligned}
& 28.32 \\
& 0.02832 \\
& 0.04381 \\
& 0.0038
\end{aligned}
$$

Temperature

$$
5 / 9\left({ }^{\circ} \mathrm{F}-32\right)
$$

degree celsius $\left({ }^{\circ} \mathrm{C}\right)$

Mass

907.2

Flow per Area

$$
0.01093 \text { cubic meter per second per }
$$
square kilometer $\left(\mathrm{m}^{2} / \mathrm{s}\right) / \mathrm{km}^{2}$ 
National Geodetic Vertical Datum of 1929 is a geodetic datum derived from the average sea level over a period of many years at 26 tide stations along the Atlantic, Gulf of Mexico, and Pacific Coasts and as such does not necessarily represent local mean sea level at any particular place. To establish a more concise nomenclature, the term "NGVD of 1929" is used in place of "Sea Level Datum of 1929" or "mean sea level." 


\title{
WATER QUALITY OF THE NEUSE RIVER, NORTH CAROLINA \\ Variability, pollution loads, and long-term trends
}

\author{
By \\ Douglas A. Harned
}

\begin{abstract}
Interpretation of water quality data collected by the U.S. Geological Survey for the Neuse River, North Carolina, has identified water-quality variations, characterized the current condition of the river in reference to water-quality standards, estimated the degree of pollution caused by man, and evaluated long-term trends in concentrations of major dissolved constituents.

Two sampling stations, Neuse River at Clayton (02087500) and Neuse River at Kinston (02089500) have more than 12 years of water-quality data collected during the period from 1955 to 1978. The Clayton station provides information on the upper fourth of the basin $\left(1,129 \mathrm{mi}^{2}\right.$ ) which includes several urbanized areas, including Raleigh, N.C., and part of Durham, N.C. The Kinston station provides information from the predominately rural midsection of the basin $\left(2,690 \mathrm{mi}^{2}\right)$. A network of temporary stations on small rural streams in the Neuse River and adjacent basins provide an estimate of baseline or essentially unpolluted water quality.

Overall, the water quality of the Neuse River is satisfactory for most uses. However, dissolved-oxygen, iron, and manganese concentrations, $\mathrm{pH}$, and bacterial concentrations of en reach undesirable levels. Concentrations of cadmium, selenium, and lead also periodically peak at or above criterion levels for domestic water supply sources. Nutrient levels are generally high enough to allow rich algal growth.

Sediment concentrations in the Neuse are high in comparison to pristine streams, however, the impacts of these high levels are difficult to quantify. Sediment and nutrient concentrations peak on the leading edge of flood discharges at Clayton. At Kinston, however, the discharge and sediment concentration peak almost simultaneously.
\end{abstract}


Changes in algal dominance, from genera usually associated with organically enriched waters to genera that are less tolerant to organic enrichment, indicate improvement in water quality of the Neuse since 1973. These changes, along with a reduction in total organic carbon concentrations, coincide with activation in 1976 of a new waste-water treatment plant for the Raleigh metropolitan area.

The amount of dissolved inorganic pollution in the Neuse was determined by subtracting estimated natural loads of dissolved constituents from measured total loads. Pollution makes up approximately 50 percent of the total dissolved material transported by the Neuse.

Two different data transformation methods allowed trends to be identified in constituent concentrations. Both methods recomputed concentrations as if they were determined at a constant discharge over the period of record. Although little change since 1956 can be seen in many constituents, increases of over 50 percent are shown for potassium and sulfate concentrations. These long-term increases indicate the increasing impact that man has had on the Neuse River, in spite of improved wastewater treatment in the basin. The increase in sulfate is probably largely due to increased long-term inputs of sulfur compounds from acid precipitation.

\section{INTRODUCTION}

Growth of population, urbanization, and industrialization in North Carolina has brought a corresponding increase in water pollution. In 1972, to help identify current and emerging water-quality problems, the U.S. Geological Survey joined with the North Carolina Department of Natural Resources and Community Development in designing and implementing a statewide water-quality monitoring program (Wilder and Simmons, 1978). As an out-growth of this program, the U.S. Geological Survey devised a study of the water quality of the large rivers in North Carolina. The program incorporates strategically located streamflow gaging and water-sampling stations in nine river basins. Each station serves to continuously update evaluations of river water quality.

The Geological Survey's study has three major goals:

1. Definition of variation in water quality,

2. Determination of pollution loads in streams, and,

3. Determination of trends in water quality.

Identification of the presence of dissolved and suspended materials in stream waters, and knowledge of how the amounts of these materials change with stream conditions is critical to any evaluation of stream contamination. It is also important to separate pollution, defined here as any substance that is present in the stream as a result of man's activities, from the natural water-quality of the stream. Finally, the evaluation of long-term trends in water quality provides a historical perspective on the changing character of the stream. 


\section{PURPOSE AND SCOPE}

The purpose of this report is to present the results of analyses of water-quality data for the Neuse River collected at Clayton and Kinston from 1956 to 1977. The results of this study are organized in a manner designed to allow comparison to results produced from studies, currently in progress, of eight other North Carolina basins. First, a basin description gives characteristics which have important relationships to water quality. These characteristics include population and land-use distributions, physical features of the basin such as topography and geology, industrial and municipal wastedisposal points, and on-going programs of stream-channel modification for flood-control or navigation purposes. Second, a summary of water-quality analyses gives an overview of the condition of the river. Next, an accounting of pollution and baseline water quality reveals the effect man has had on the stream. Finally, water-quality changes throughout the total data-collection period allow an examination of past and projected trends in pollution of the Neuse River.

The methodology used in evaluating long-term trends receives special emphasis in this report. This is because this methodology is to be used in similar studies on other large rivers in North Carolina.

\section{DATA COLLECTION}

Data from two key locations on the Neuse, near Clayton and at Kinston (fig. 1), allow characterization of water-quality variation, pollution loads, and historical changes in quality in the river.

The station near Clayton (Neuse River near Clayton, 02087500) provides information about the Piedmont reach of the Neuse, an area where water quality is of particular concern because of expanding water-supply needs. Chemical data for the Neuse River were collected near Clayton during the 1944, and 196467 water years. Data collected from 1956 to 1958 at a station 9.9 miles downstream from Clayton (Neuse River near Selma, 02087530) has been merged with the Clayton data for the purpose of analysis in this report. Samples collected during these years were analyzed for major ions, dissolved solids, hardness, specific conductance and $\mathrm{pH}$. An expanded program of water-quality data collection at the Clayton station began in 1973. Periodic measurements of organic substances, nutrients, toxic materials, suspended materials, metals, and biota are now also part of the ongoing study.

The sampling station at Kinston (02089500) provides water-quality data at a point within the Coastal Plain reaches of the Neuse River. This station is part of the National Stream Quality Accounting Network (NASQAN) of the U.S. Geological Survey. NASQAN is a program devised to monitor water quality in major river basins across the United States.

Chemical data were collected from the Kinston station during the 1950, 1955-56 and 1958-67 water years. The current program of monthly water-quality data collection at Kinston began in 1973. This station measures the output 


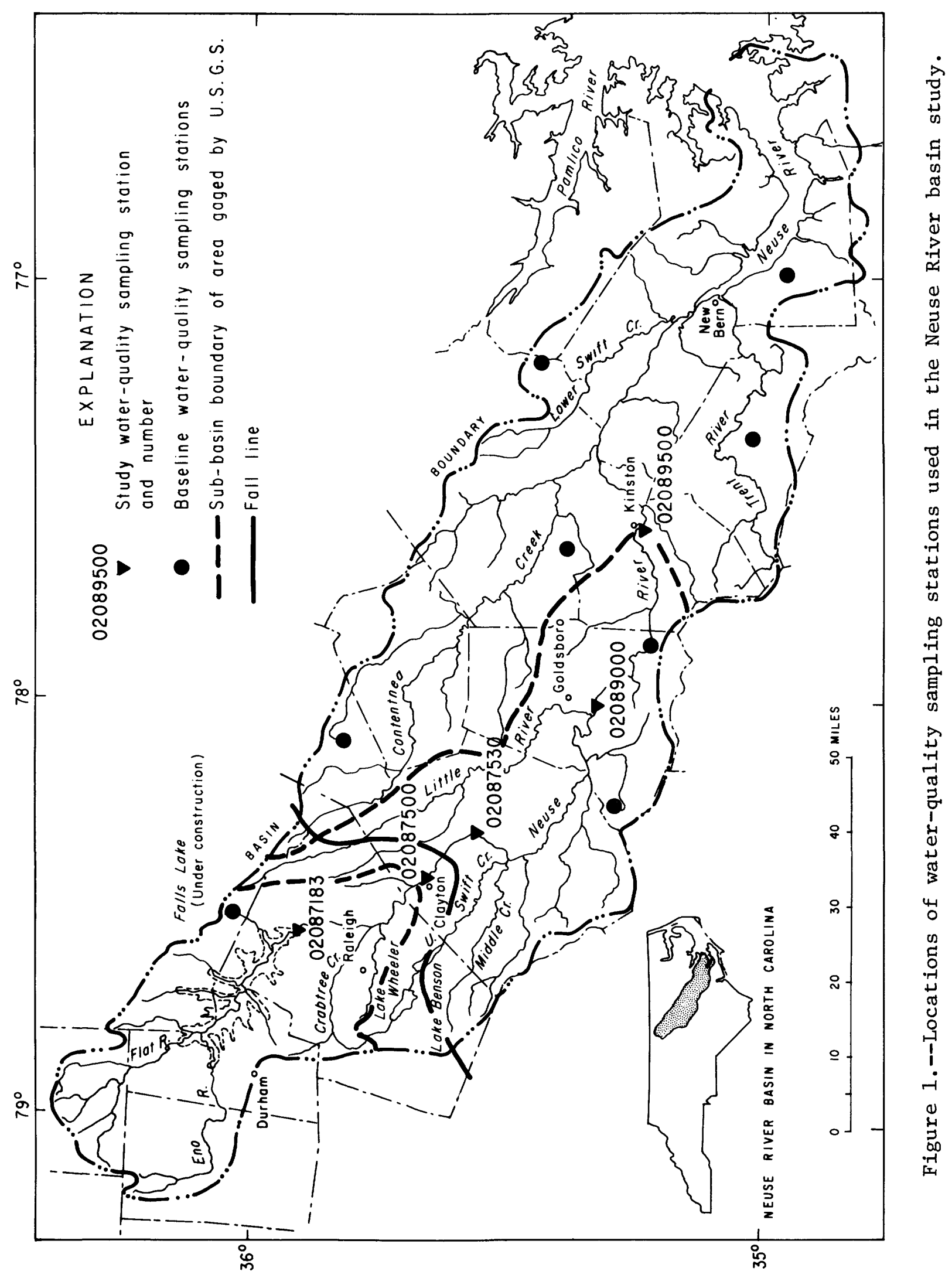


from a major portion of the Neuse River basin which is, in turn, the input to the downstream estuary system.

Two other sampling stations, Neuse River near Falls (02087183) and Neuse River at Goldsboro (02089000), were employed to fill gaps in daily specific conductance record of the Clayton and Kinston stations. The periods of data collection for the major stations employed in this study are shown in figure 2 .

Nine stations located in undeveloped tributary basins give a measure of water quality under as near natural conditions as is possible for the basin. With a measure of baseline water-quality conditions, the effect of man can be defined. The methods employed to evaluate baseline water quality are discussed in detail in the pollution section. The locations of these baseline waterquality stations are shown in figure 1.

\section{RECENT WATER-QUALITY STUDIES}

Recent studies have reemphasized the importance of the Neuse River as a water-supply source (Putnam and Lindskov, 1973), and a recreational and ecological resource (North Carolina Department of Natural and Economic Resources, 1975a; Hobbie and Smith, 1975). The first complete "Area-wide Waste Treatment Management Plan" in the nation, the pilot of many such plans mandated by section 208 of the Federal Water Pollution Control Act Amendments of 1972 (Public Law 92-500), encompasses much of the upstream area of the Neuse River basin (Triangle $\mathrm{J}$ Council of Governments, 1977). This plan instigated a number of detailed water-quality studies designed to evaluate problems of point-source pollution, such as the end-of-the-pipe effluents of industry and of municipal treatment plants, and nonpoint source pollution, such as rainwater washoff of pollutants from construction sites and urban areas. According to the Triangle $J$ Council of Governments (1976), the majority of tributary streams in the upper Neuse basin are water-quality limited. That is, additional measures beyond secondary treatment of municipal sewage and best-practicable-technology treatment of industrial wastewater will be required to return the streams to fishable and swimmable conditions.

A major flood-control and water-supply reservoir is under construction on the upper Neuse River west of Falls, N.C. The environmental impact statement for this project is an exhaustive catalogue of the environmental effects of the reservoir (U.S. Army Corps of Engineers, 1973). Optimal use of the reservoir for recreation and water supply hinges on acceptable water quality. Furthermore, this reservoir will directly impact water-quality variation, pollution loads and trends in the Neuse River. Current water-quality and pollution trends are particularly interesting in light of the changes that will result from the filling of this reservoir. 




EXPLANATION

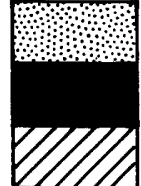

Daily discharge record

Chemical data collected

Daily specific conductance data

Figure 2.--Period of record for water-quality sample collection, and discharge measurement at stations used in the Neuse River study. 


\section{ACKNOWLEDGMENTS}

R. S. Taylor, of the N.C. Department of Natura1 Resources and Community Development, provided valuable insight and information about the history of the operation of the Raleigh waste-water treatment plant. Charles C. Daniel III developed the discharge-normalization technique for this study. Joseph $S$. Riggsbee provided valuable assistance with computer programing.

J. R. Flowers, Jr., of Clayton, N.C., measured daily specific conductance and water temperature for 1974-75. B. R. Creech, of Selma, N.C., took daily conductance and temperature measurements for 1976-1978. Some of the dissolved oxygen, chemical oxygen demand, biochemical oxygen demand, and fecal coliform bacteria data used in this report were collected by scientists and technicians working for the North Carolina Department of Natural Resources and Community Development.

Catherine E. Harrington and Karen Miles-English typed the manuscript. John Teel drafted the illustrations.

\section{BASIN DESCRIPTION}

The Neuse River drains $5,710 \mathrm{mi}^{2}$, about 12 percent of the total 1 and area of North Carolina. The drainage basin lies within both the Piedmont and Coastal Plain provinces in the eastern part of the state (fig. 1). Beginning at the confluence of the Eno and Flat Rivers in Durham County, the Neuse flows southeast for 222 river miles, emptying finally into Pamlico Sound.

Important tributaries of the Neuse River include the Eno River (drainage area $253 \mathrm{mi}^{2}$ ), the Flat River $\left(169 \mathrm{mi}^{2}\right)$, Crabtree Creek (143 $\mathrm{mi}^{2}$ ), Upper Swift Creek and Middle Creek (283 $\mathrm{mi}^{2}$ ), Little River (323 $\mathrm{mi}^{2}$ ), Contentnea Creek (849 $\mathrm{mi}^{2}$ ), Lower Swift Creek $\left(322 \mathrm{mi}^{2}\right.$ ), and the Trent River (519 $\mathrm{mi}^{2}$ ).

The streamflow-measuring and water-sampling station at Clayton (fig. 1) gages a basin area of $1,129 \mathrm{mi}^{2}$, which includes the Eno and Flat Rivers and Crabtree Creek. The Kinston station, downstream from Clayton (fig. 1) gages an area of $2,690 \mathrm{mi}^{2}$, including the drainage area of the Clayton station and the Little River.

\section{CLIMATE}

The climate of the Neuse River basin is temperate, characterized by moderate winters and humid summers. Average monthly temperatures usually peak in July around $77^{\circ} \mathrm{F}\left(25^{\circ} \mathrm{C}\right)$ and drop to lows near $43^{\circ} \mathrm{F}\left(6^{\circ} \mathrm{C}\right.$ ) in January (U.S. Army Corps of Engineers, 1964). The mean annual air temperature in the basin is $59^{\circ} \mathrm{F}\left(15^{\circ} \mathrm{C}\right)$.

Precipitation is greatest near the coast, decreasing in the inland direction. At New Bern, near the mouth of the Neuse River, annual precipitation averages 56 inches within a range of 41 to 70 inches (U.S. Army Corps of Engineers, 1964). Near the headwaters of the basin, annual precipitation recorded at the Raleigh-Durham Airport station averages 44 inches with a range of 35 to 
52 inches. Rainfall is usually greatest during the summer months of June, July, and August, and may be especially intense during thunderstorms and hurricanes. Annual snowfall at the New Bern and Raleigh-Durham Airport weather stations averages 4 inches and 7 inches, respectively.

\section{TOPOGRAPHY}

The Neuse River basin lies within two physiographic provinces. The basin west of Clayton is in the Piedmont province. The eastern half of the basin lies within the Coastal Plain. The Fall Line (fig. 1) is the border between these two areas.

Deeply eroded valleys and rolling hills characterize the Piedmont where altitudes range from about 770 feet along the drainage divide where it passes through central Orange and Person Counties to about 160 feet along the floodplain of the Neuse near Clayton. Local relief in the Piedmont part of the basin is on the order of 150 feet. The stream channel slope of the Flat and Eno Rivers is approximately 15 feet per mile. The channel slope of the Neuse River from the confluence of the Flat and Eno Rivers to Clayton is approximately 2 feet per mile.

Southeast of Clayton, the Piedmont topography changes gradually to the flatlands of the Coastal Plain. The river slope in this eastern region is around 1 foot per mile. Swampy areas are common, flood plains are broad, and streams are sluggish in this area.

\section{GEOLOGY}

Billingsley, Fish, and Schipf, (1957), and Simmons and Heath (1979) summarize the relation between geology and water-quality for the Neuse River basin. Simmons' geochemical zones for the Neuse River basin, which are based on surficial geology and a grouping of similar water-quality analyses from samples collected at natural water-quality network sites (fig. 1), are shown in figure 3. The four geochemical zones in figure 3 closely correspond to ground-water provinces defined for the Neuse basin by Billingsley, Fish, and Schipf, (1957).

Rocks of geochemical zones I and II are generally crystalline. Granite is the rock type predominate in geochemical zone I (fig. 3). Zone II rocks are mainly massive slates and compact shales in the western part of the basin and massive slates and schists in the midsection of the basin. The surface water of zone II, particularly in the shale areas, is more mineralized than that observed for zone $\mathrm{I}$. Water is generally soft in both zones, but may be locally hard and alkaline in some shale areas of zone II.

Rocks of geochemical zone IV are sedimentary in origin and composed predominately of sand, clay and mar1. Much of the land surface is underlain by a layer of sand, causing surface water in this region to be relatively low in dissolved solids compared to the other zones. 


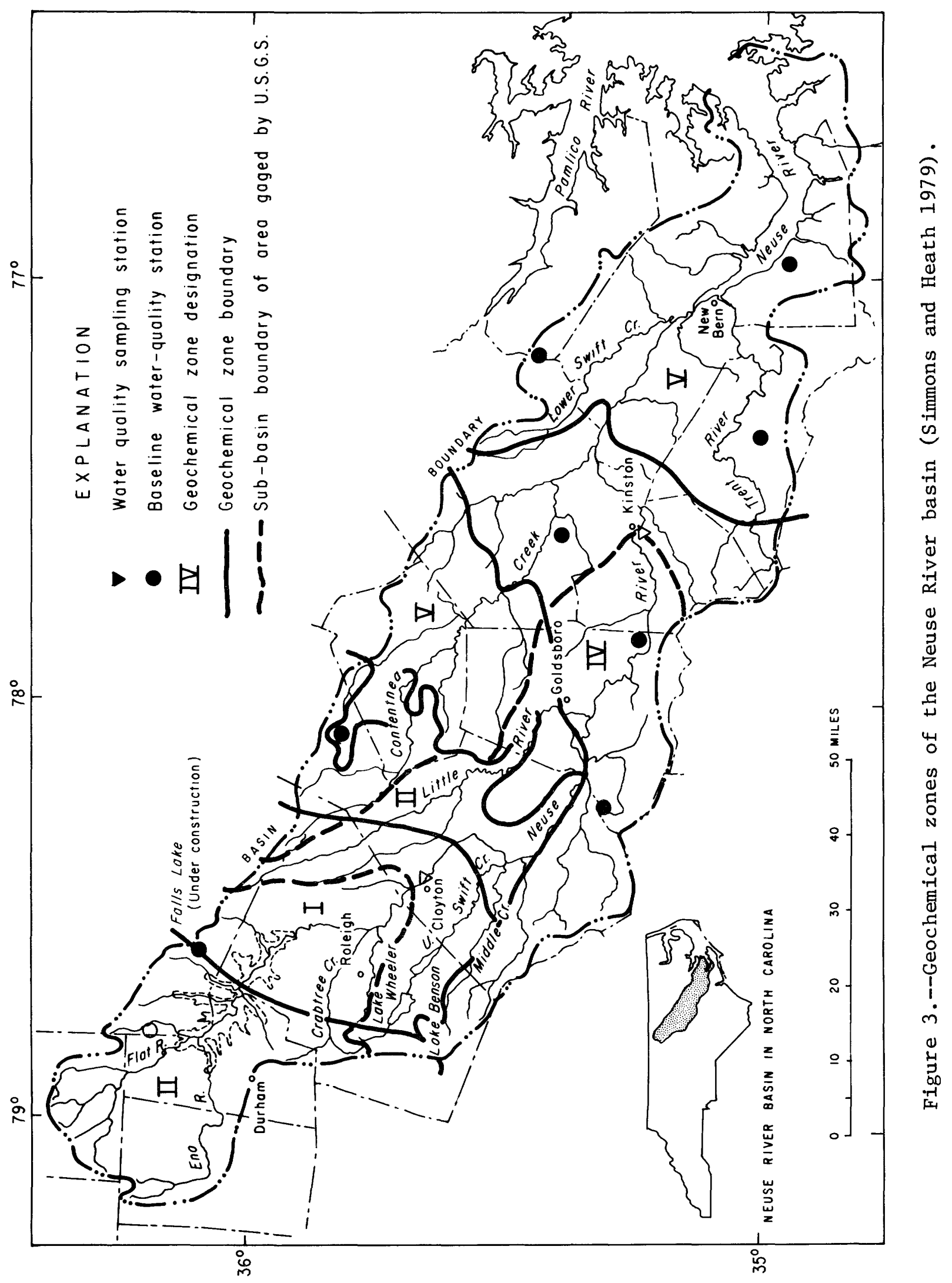


Limestone and shell beds with surface sands and clays characterize zone V. The soluble limestones and shells increase the mineralization of water in this region. Surface and ground water in this zone is generally hard.

\section{STREAMFLOW}

At Clayton the average daily discharge for 49 years of record is 1,181 $\mathrm{ft}^{3} / \mathrm{s}$ with a range from 22,900 to $44 \mathrm{ft}^{3} / \mathrm{s}$. This average discharge is approximately $1\left(\mathrm{ft}^{3} / \mathrm{s}\right) / \mathrm{mi}^{2}$ of drainage area. At Kinston the average daily discharge for 46 years of record is $2,889 \mathrm{ft}^{3} / \mathrm{s}$, with a range of 26,000 to $124 \mathrm{ft}^{3} / \mathrm{s}$. This average discharge is approximately $1.1\left(\mathrm{ft}^{3} / \mathrm{s}\right) / \mathrm{mi}^{2}$ of drainage area.

Although the greatest amount of precipitation usually comes during summer, the lowest streamflows also occur during this period. Summer temperatures and plant growth increase evaporation and transpiration (utilization of water by plants) to a point where much of the summer rainfall never reaches the streams.

Kinston lies just above the region of the Neuse River basin where tides influence streamflows. Tidal influences, which complicate data analysis, were avoided by location of the station at Kinston.

\section{POPULATION}

The 1970 population of the parts of the 17 counties that lie within the Neuse basin was 709,900 or 14 percent of the total population of North Carolina. (North Carolina Department Water and Air Resources, 1972). This represents an increase of 10 percent over the 1960 population $(636,000)$. The largest cities bordering on or lying within the basin are: Raleigh (projected 1979 population 121,577$)$, Durham $(95,438)$, Goldsboro $(26,810)$, Kinston $(23,309)$, and New Bern $(14,660)$ (U.S. Department of Commerce, 1971). In addition, there are 57 towns and villages in the basin with populations between 1,000 and 8,000 .

The distribution of 1970 population by major subbasins is shown in figure 4. Approximately 40 percent of the Neuse River basin population $(284,000$ people in 1970) reside upstream from Clayton. Almost 70 percent $(497,000$ people in 1970) of the total basin population reside upstream from Kinston. The area upstream from Clayton, which includes Raleigh and Durham, has the fastest growing population in the basin, showing an increase of approximately 70 percent from 1960 to 1970. The basin area between Clayton and Kinston, however, showed practically no increase in population during the 1960-70 period.

\section{WATER USE AND WASTE DISPOSAL}

All points of major municipal and industrial wastewater discharge in the Neuse basin are catalogued by the North Carolina Department of Natural and Economic Resources (1975b). According to their figures, one hundred sixty sources discharge approximately $170 \mathrm{ft}^{3} / \mathrm{s}$ of wastewater within the basin. This 


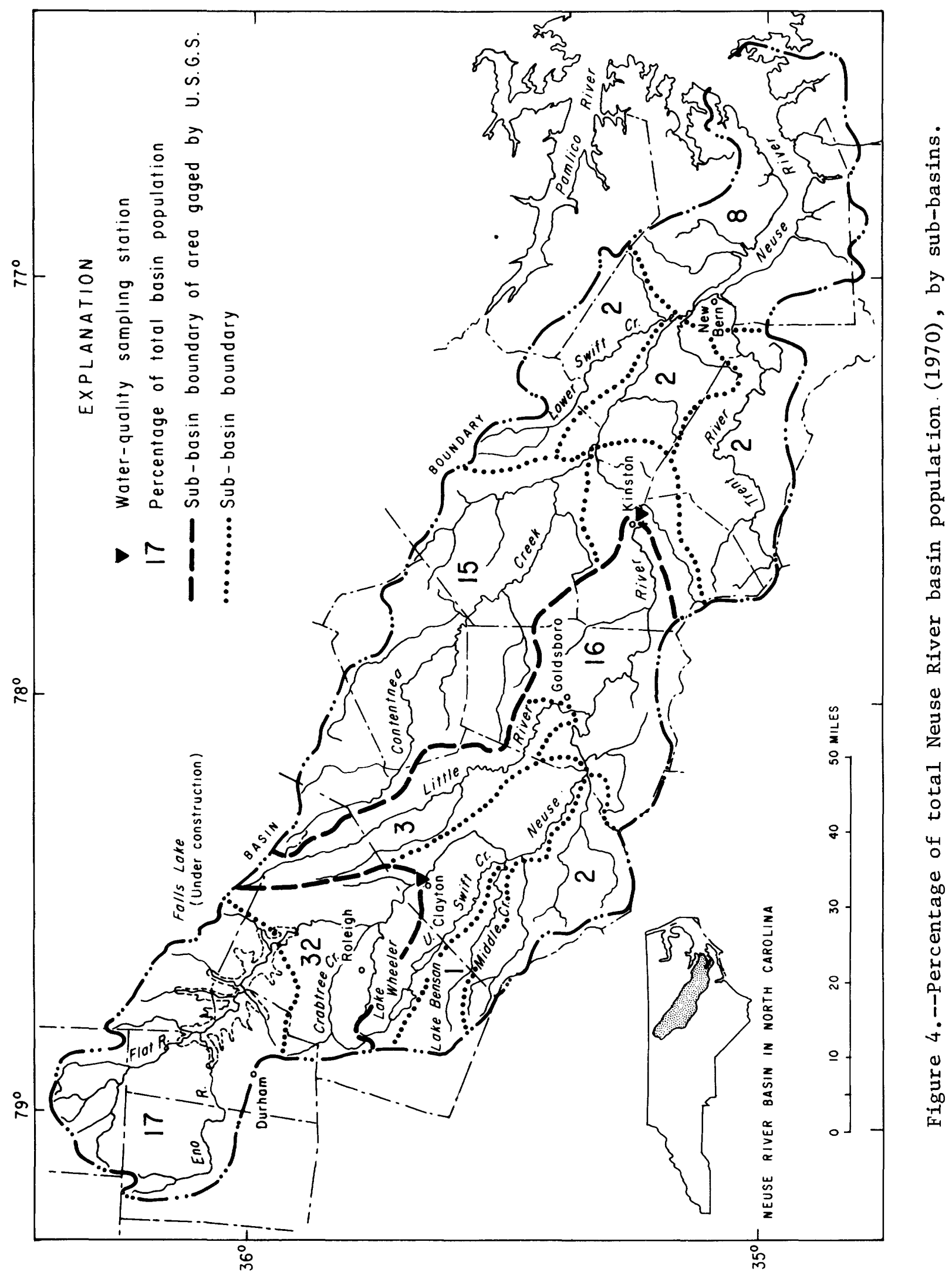


Table 1.--Major municipal and industrial wastewater discharges of the Neuse River basin (from North Carolina Department of Natural and Economic Resources, 1975b)

\begin{tabular}{|c|c|c|}
\hline 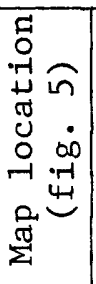 & Facility & $\begin{array}{c}\text { Effluent } \\
\text { discharge } \\
\left(\mathrm{ft}^{3} / \mathrm{s}\right)\end{array}$ \\
\hline 1 & Northside Wastewater Treatment Plant (Durham) & 13 \\
\hline 2 & Liggett and Myers (Durham County) & 1.55 \\
\hline 3 & Burlington Industries (Durham County) & 1.55 \\
\hline 4 & Neuse River Treatment Plant (Raleigh) & 29.3 \\
\hline 5 & Smithfield Municipal Treatment Plant & 1.7 \\
\hline 6 & Burlington Industries (Wake County plant) & 3.7 \\
\hline 7 & Goldsboro Municipa1 Treatment Plant & 8.5 \\
\hline 8 & Kinston Municipal Treatment Plant & 7.8 \\
\hline 9 & E. I. Dupont (Kinston) & 5.9 \\
\hline 10 & Carolina Power and Light (Wayne County) & 2.5 \\
\hline 11 & Ne11o Teer Quarry (Princeton) & 2.3 \\
\hline 12 & Wilson Municipal Plant No. 1 & 3.9 \\
\hline 13 & Wilson Municipal Plant No. 2 & 4.5 \\
\hline 14 & Farmville Municipal Plant & 2.2 \\
\hline 15 & Weyerhaeuser (Craven County) & 54.3 \\
\hline 16 & New Bern Municipal Plant & 5 \\
\hline
\end{tabular}


compares to the natural 7-day, 10-year minimum low flow at Kinston of $210 \mathrm{ft}^{3} / \mathrm{s}$. Sixteen of these sources account for nearly $150 \mathrm{ft}^{3} / \mathrm{s}$ or 88 percent of wastewater discharge (table 1). The locations of these 16 major effluent sources and the percentages of total effluent discharge by sub-basin are shown in figure 5. A comparison of population distribution by sub-basin (fig. 4) and sub-basin wastewater discharge (fig. 5) reveals a general correspondence of wastewater discharges to population. However, one discrepancy appears: the Weyerhaeuser plant in Craven County uses particularly large amounts of water relative to the county population. In the Neuse River basin upstream from Kinston, wastewater discharge is dominated by municipal waste-water treatment plant effluent which is largely a function of population.

Upstream of Clayton, $45 \mathrm{ft}^{3} / \mathrm{s}$ or 83 percent of the total wastewater discharged into the Neuse and its tributaries originates from 26 municipal wastewater treatment facilities. Two of these plants, the Durham Northside plant and the Raleigh Neuse River plant, discharge approximately $35 \mathrm{ft}^{3} / \mathrm{s}$ or 77 percent of the total point-source wastewater discharged into the Neuse above Clayton.

In the segment of the basin between Clayton and Kinston, $14 \mathrm{ft}^{3} / \mathrm{s}$ or 95 percent of the total $15 \mathrm{ft}^{3} / \mathrm{s}$ of wastewater discharged into the Neuse and its tributaries originates from 10 municipal wastewater treatment facilities. The Goldsboro wastewater treatment plant alone discharges $9 \mathrm{ft}^{3} / \mathrm{s}$ or 59 percent of the total effluent discharged into the Neuse in the basin area between Clayton and Kinston. Industrial and private sources account for the remaining wastewater discharge.

Recent water-pollution legislation has induced most of the major municipalities within the Neuse River basin to upgrade their waste treatment facilities. Raleigh's Neuse River wastewater treatment plant serves as an example of this trend. This plant employs an advanced three-stage treatment process designed to remove 98 percent of organic materials and suspended solids in the waste when operated properly. Upgraded waste treatment, if matched to the needs of the growing population in an ongoing process, should maintain or improve water quality of the Neuse River for many major pollutants. However, current wastewater treatment practice does not remove all materials of concern, including nutrients and many dissolved materials. Thus, coinciding with increases of population, increases of these pollutants probably will appear in streams.

\section{HYDROLOGIC MODIFICATIONS}

Approximately 48 man-made lakes and ponds (excluding small farm ponds) are scattered throughout the Neuse watershed. Five of these impoundments make up 57 percent of the 4,657 total acres of water surface area (Fish, 1968). Of these four large lakes, three are water-supply reservoirs, and two are power plant cooling ponds. Lake Wheeler (500 acres) and Lake Benson (440 acres), both impoundments on Swift Creek, are water supply reservoirs for Raleigh. Lake Michie (507 acres) on the Flat River, is the reservoir for Durham. Quaker Neck Lake (600 acres) in Johnston County and Lee Lake (600 acres) serve as cooling ponds for Carolina Power and Light Company. 


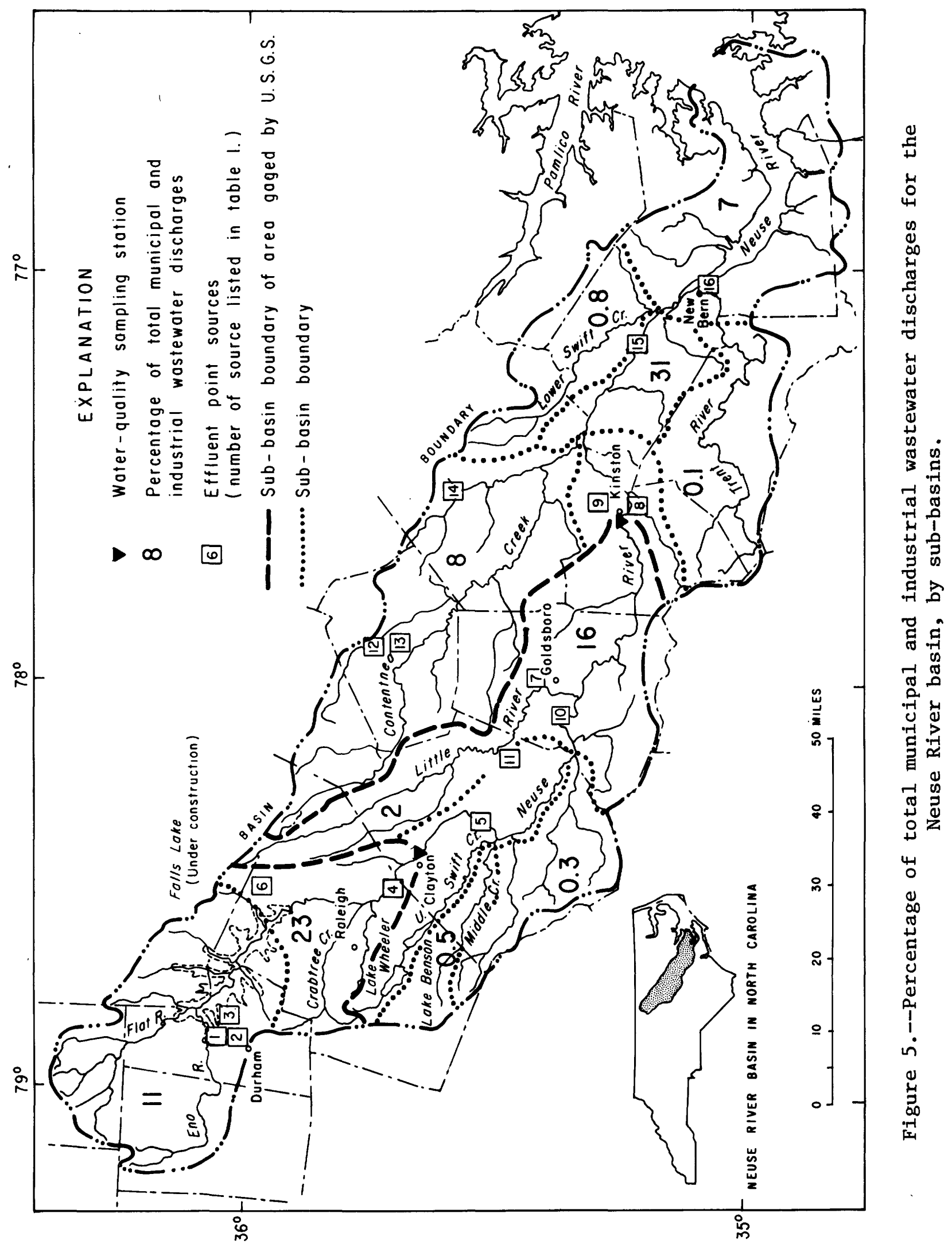


of 13 reservoir projects proposed by the U.S. Army Corps of Engineers (1964) only the Falls Lake project has been funded. The Falls Lake dam will be located near the village of Falls and the main body of the reservoir will be in Durham County and northern Wake County. The lake will be 22 miles long, extending upstream from the dam at Falls into the Flat and Eno Rivers. When completed, the 13,000 acre reservoir will increase the total water surface area of lakes and reservoirs in the Neuse basin by a factor of three. This impoundment will have a profound environmental impact on the Neuse River from the head of the lake to Pamlico Sound. The impoundment will trap sediment, while an increase in carrying capacity will result in channel scouring downstream from the damsite. A change in downstream sediment particle size may result from this altered sedimentation-scouring scenario. Some downstream bank erosion and draining of swampy areas within the floodplain may occur. Changes in water quality will result from the altered stream regimen. Pollutant constituents associated with sediment will be affected, and dissolved oxygen levels will reflect new reaeration and biological relationships in and downstream from the lake.

Since 1896 the U.S. Army Corps of Engineers has modified 310 miles, or 21 percent of the approximate 1,500 miles of river channel in the Neuse basin (U.S. Army Corps of Engineers, 1977). These channel modifications include: cleaning, snagging, deepening and straightening of channels, excavation of new channels and other construction. Currently, 1979, flood-protection schemes are proposed for an additional 75 river miles.

The U.S. Soil Conservation Service has also played a major role in alteration of tributaries of the Neuse. Four major stream channelization projects have been completed, and four other channel modification projects have been approved or are underway (North Carolina Department of Natural and Economic Resources, 1976).

Channelization, and other stream modifications, directly impact a wide range of environmental variables. Stream realignment, or clearing and snagging activities cause temporary increases in suspended sediment concentrations and turbidity. Channelization is generally undertaken to alter the flow regime to facilitate rapid land drainage. Hydrogeologic effects of channelization include reduced surface ponding, increased water velocities, and rapid peaking of discharge during floods. Sediment carrying capacity increases with increased flow velocity. Problems of erosion and increased sediment concentrations are often encountered in both urban and rural areas where extensive channel modification is employed to improve drainage efficiency. Both temporary and longterm effects of stream modification are reflected by changes in stream-centered animal and plant populations.

\section{WATER QUALITY VARIATION}

The quality of water in the Neuse River is satisfactory for most uses. However, several water-quality parameters indicate problems, and certain constituents occur at undesirable levels. 
Measurements at Clayton and Kinston of specific conductivity, temperature and turbidity show no outstanding extreme values. However, $\mathrm{pH}$ and dissolved oxygen levels are often lower than the optimal ranges suggested by the U.S. Environmental Protection Agency (EPA, 1976) for protection of freshwater aquatic life.

Suspended sediment concentrations at clayton show a response to flood flows characterized by a rapid peaking at the beginning of a flood, followed by a recession. This response is characteristic of discharge-sediment and discharge-pollutant relationships often observed for streams in urbanized areas. At Kinston, suspended sediment concentration is more independent of discharge than at Clayton. This is principally due to increased basin size and lower relief that results in dilution and lower flow velocity.

The predominate cations in Neuse River water are potassium and sodium, and the dominant anion is bicarbonate. The major ionic constituents occur at concentrations that are satisfactory for most uses of the water.

Trace metals generally occur in low concentrations at both stations. Only iron and manganese concentrations are consistently above levels suggested for domestic water supply. Cadmium, selenium, and lead concentrations periodically rise above EPA (1976) criteria levels.

Nutrient levels are usually higher than the lower limits required for algal growth. Recently (July 1979), large algal blooms have appeared in the segment of the Neuse River downstream from the construction site of the Falls reservoir, and upstream from Clayton (S. Howe, U.S. Geological Survey, personal commun., July 15, 1979). Although eutrophication currently is not a major concern in the Neuse River, future problems may arise in estuary areas or the Falls reservoir.

High ammonia and total organic carbon concentrations at Clayton are indicative of stream pollution. High total organic carbon concentrations also occur at Kinston, indicating organic carbon enrichment of the stream.

The biological data available for Clayton and Kinston characterize the Neuse River as eutrophic and organically enriched with some degree of fecal contamination. Fecal coliform and fecal streptocci bacteria occur at levels exceeding the recommended criteria (EPA, 1976) for bathing waters. Coliform levels at Kinston are especially high. Interestingly, five-day biological oxygen demand tests indicate that levels of organic contamination are frequent1y higher at Clayton than at Kinston.

Changes in dominance of algal genera in the Neuse in 1976 correspond to the opening of the Neuse River Wastewater Treatment Plant, a new facility designed to serve the Raleigh metropolitan area. These observations suggest improvement in the water-quality of the Neuse River following the activation of this treatment plant. 


\section{PHYSICAL CHARACTERISTICS}

\section{Dissolved oxygen and water temperature}

Oxygen, while plentiful in the atmosphere, is often in limited supply in water. During summer months, high temperatures reduce the solubility of oxygen in water. Subsequently, evaluation of dissolved oxygen levels in streams is important for the critical high-temperature months.

Water temperatures follow ambient air temperatures, but are buffered from extreme values of air temperature by the slower heating and cooling rate of the water. This is demonstrated by the plot of 1976 water and air temperatures shown in figure 6 . Water temperature statistics are given in table 2 .

The saturation of dissolved oxygen varies inversely with temperature. For a summer-month water temperature range of $18^{\circ}-27^{\circ} \mathrm{C}$ the predicted saturation of dissolved oxygen will be 9.5 to $8.0 \mathrm{mg} / \mathrm{L}$. However, at Clayton the 1974-76 daytime mean dissolved-oxygen level for this range of temperatures was 4.8 $\mathrm{mg} / \mathrm{L}$. At high daytime water temperatures, observed levels are substantially lower than saturation levels (fig. 7). This difference is in part accounted for by the presence of oxygen-demanding materials, often predominated by organic pollution, in the stream. (See Biological Characteristics).

A value of $5.0 \mathrm{mg} / \mathrm{L}$ of dissolved oxygen is commonly promulgated as a target criterion level necessary to maintain a varied fish population, while 4.0 $\mathrm{mg} / \mathrm{L}$ is cited as the minimum concentration necessary to permit persistence of sizable tolerant species populations. However, dissolved-oxygen levels below $5.0 \mathrm{mg} / \mathrm{L}$ will not necessarily cause fish kills, especially if the depleted oxygen levels occur only for brief periods.

The observed summer daytime dissolved-oxygen levels at Clayton hover very closely to the minimum criterion level, and periodically decrease to lower values (fig. 7). During the period of high summer temperatures, dissolved oxygen concentrations are less than $5.0 \mathrm{mg} / \mathrm{L}$ in approximately 60 percent of the samples, occasionally decreasing to as low as $2 \mathrm{mg} / \mathrm{L}$. These low dissolvedoxygen values are the net result of a combination of factors including high summer temperature, low rates of reaeration due to low discharge, and waste water effluent. Dissolved-oxygen statistics for Clayton are given in table 2 .

In contrast to the low concentrations observed at Clayton, daytime dissolved-oyxgen levels at Kinston are generally high (table 2). Dissolvedoxygen levels at or above saturation are common at the Kinston site (fig. 8). These observed high dissolved-oxygen values probably are due to presence of extensive algae growths during summer months. (See Biological Characterisitcs). However, oxygen from algae photosynthesis is only produced during daylight hours. At nightfall in water containing large concentrations of algae, high dissolved-oxygen levels fall continuously as photosynthesis ceases and plant and animal respiration utilizes the available oxygen (Hines and others, 1977). Although there is no data available for nighttime summer dissolved-oxygen levels, it is very likely, in light of the summer algae 


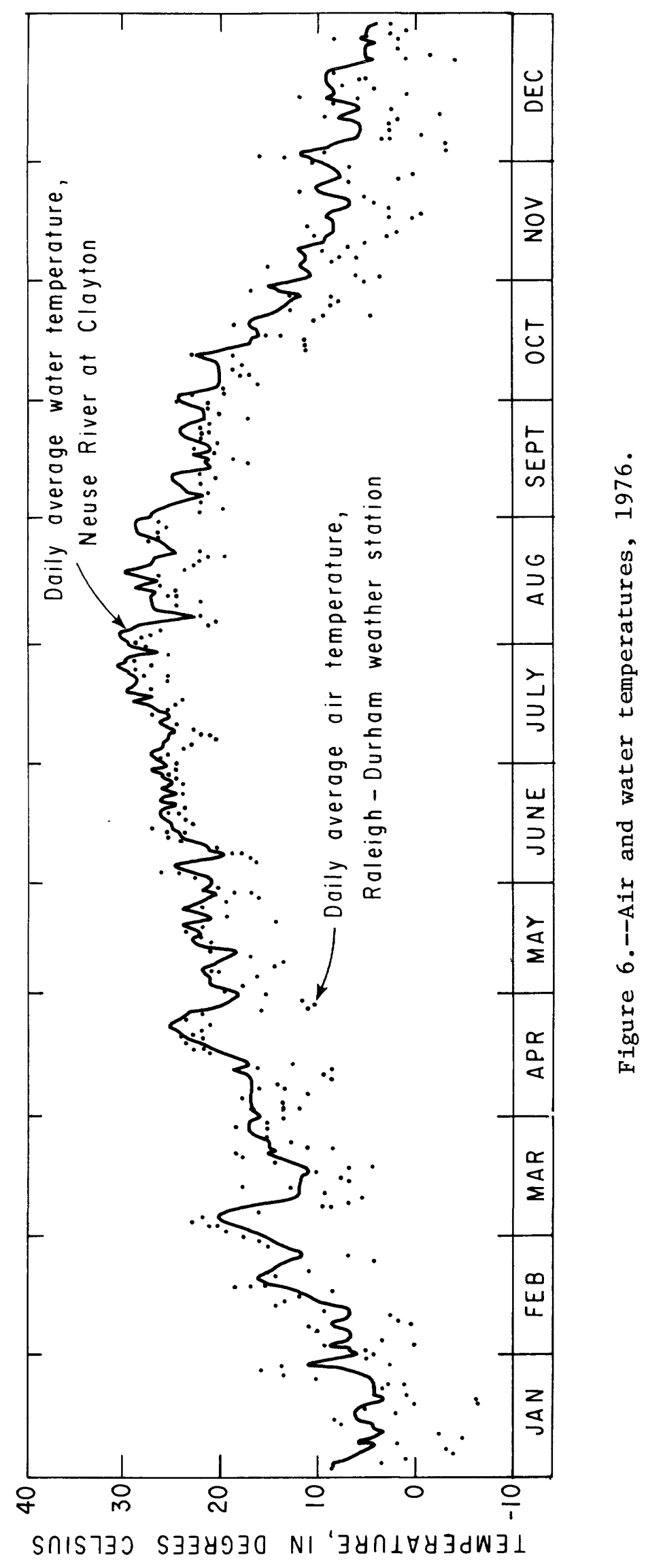




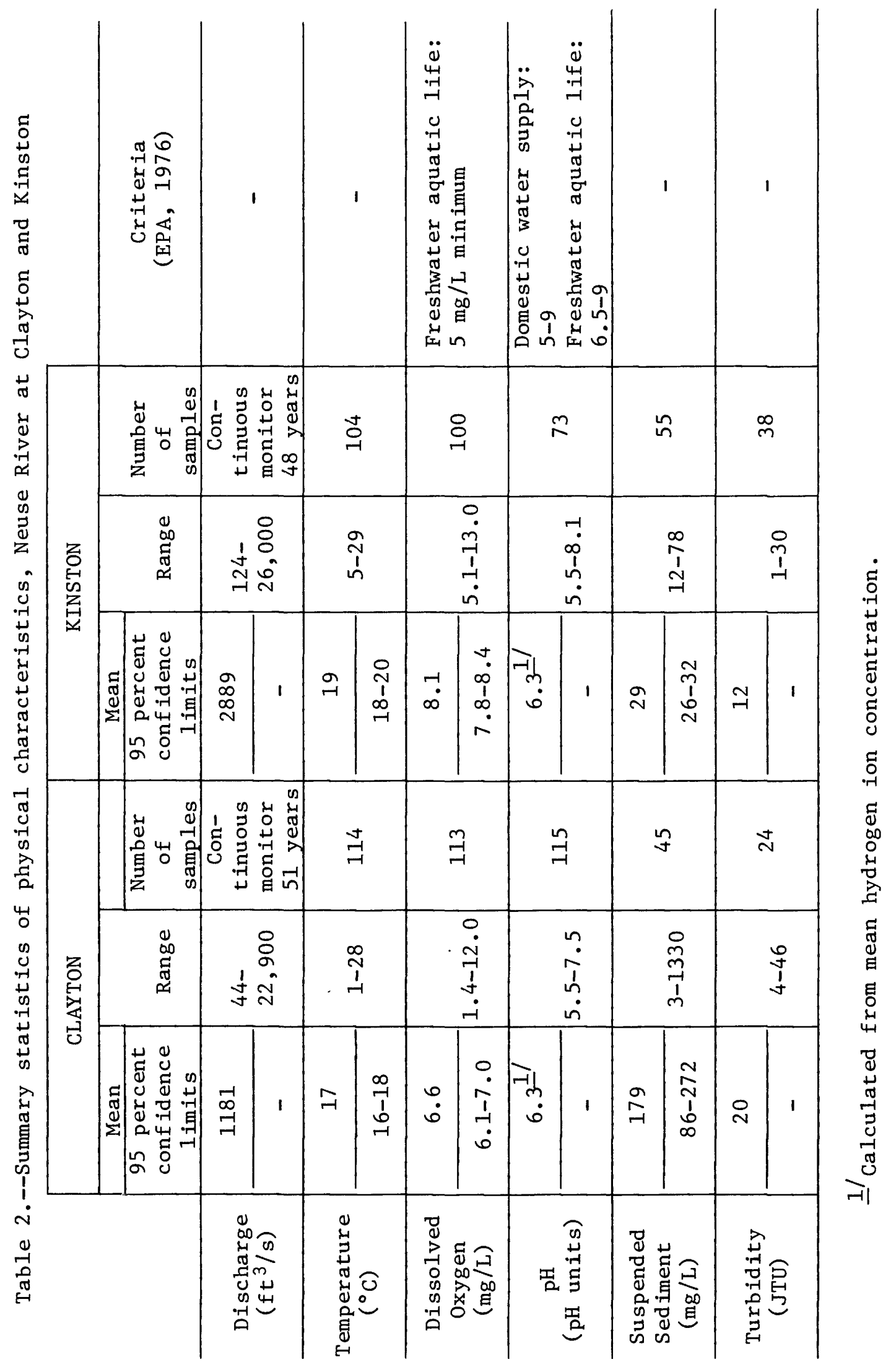




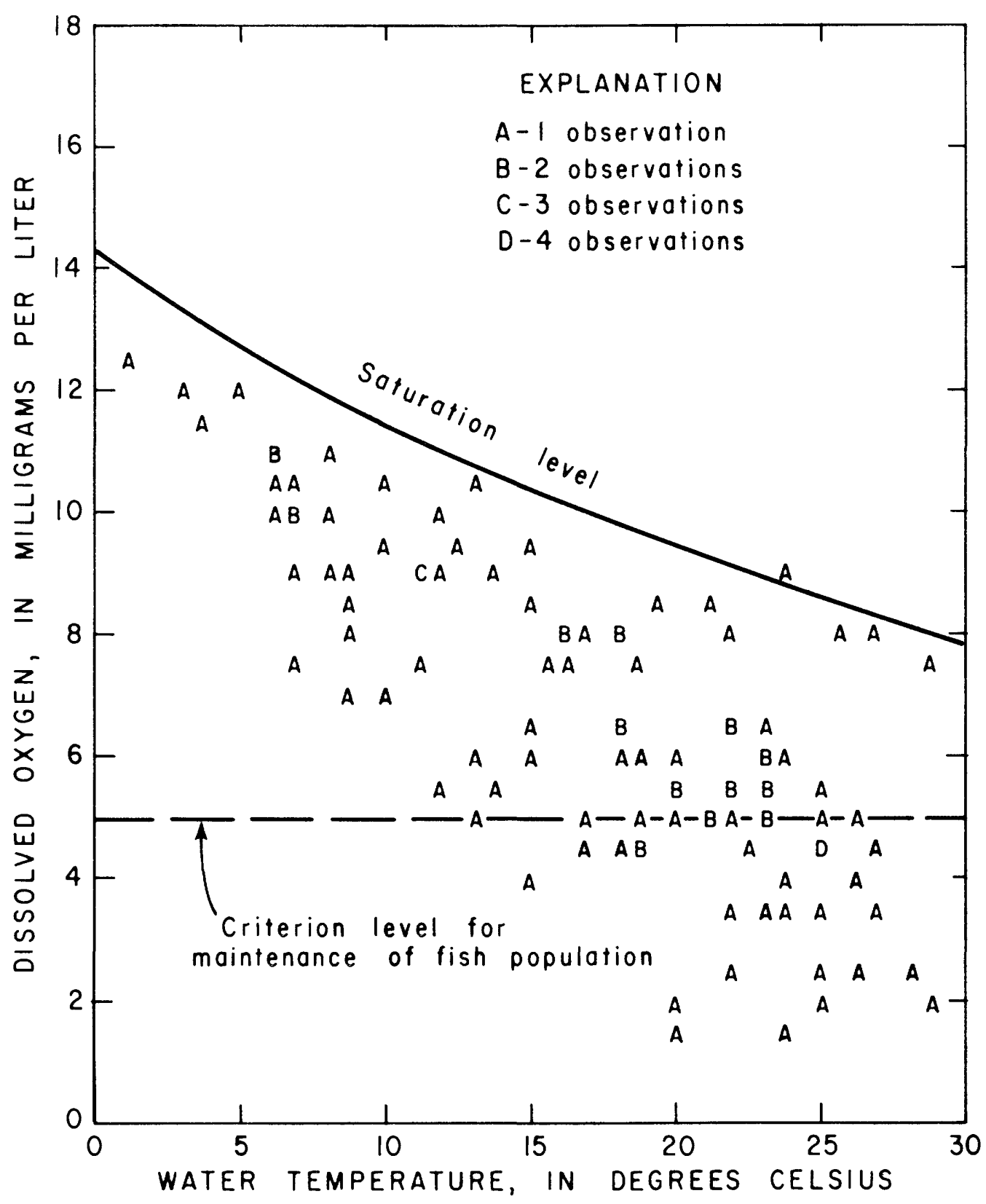

Figure 7.--Dissolved-oxygen concentrations versus water temperatures for the Neuse River at Clayton, 1974-77 water years. 


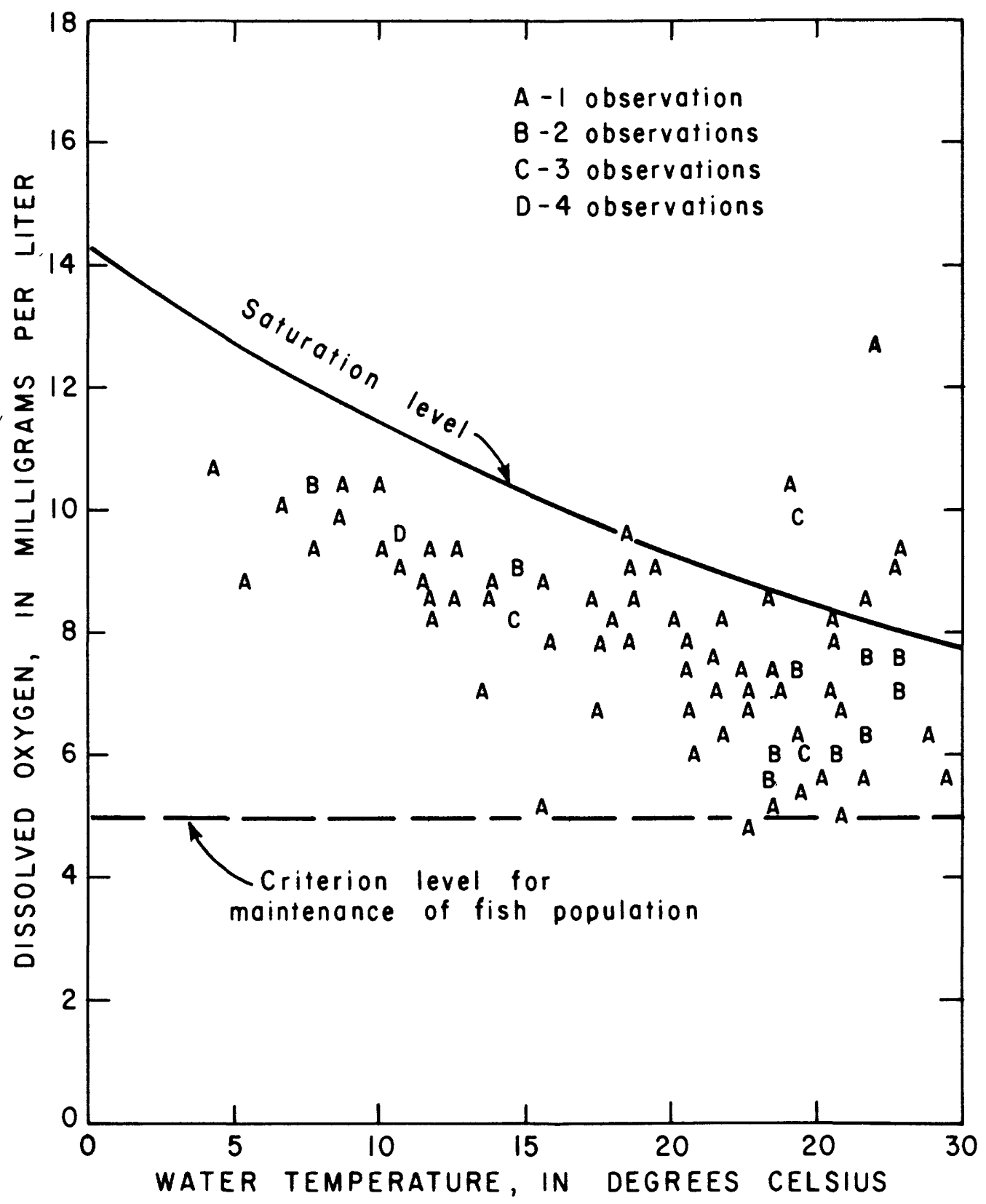

Figure 8.--Dissolved-oxygen concentrations versus water temperatures for the Neuse River at Kinston, 1974-77 water years. 
concentrations, that respiration oxygen demands at both Clayton and Kinston depress the daytime dissolved-oxygen buildup.

The oxygen level in a stream can be deduced from the fish population found in the stream. Not surprisingly, fish found in the main channel of the Neuse River (Fish, 1968) are predominately species with tolerance for low dissolved oxygen concentrations: sunfish (approximately 35 percent of fish caught), catfish (33 percent), and carp or shad (11 percent each depending on location). These fish counts were evaluated by creel census, and therefore may not reflect the true composition of the fish community.

Future improvement in dissolved oxygen concentrations may be a result of the current trend to upgrade wastewater treatment plants. Improved wastewater treatment will reduce the amount of oxygen-demanding organic material introduced into the river, in turn lowering the recurrance of periods of low dissolved-oxygen concentrations. However, increases in population may offset the progress accomplished through effective wastewater treatment by causing increases in the volume of treated wastewater that is introduced into the stream systems. In particular, areas immediately downstream from treatment plant discharge points will continue to be highly impacted by depressed dissolved-oxygen concentrations.

\section{pH}

The distribution of $\mathrm{pH}$ values observed for Clayton is similar to the Kinston distribution. The mean-hydrogen ion concentration for clayton is not statistically different from the mean concentration for Kinston, both of which give a $\mathrm{pH}$ of 6.3. The $\mathrm{pH}$ data for both stations ranges between 5.5 and 9.4; however, the majority of values fall within a range of 5.7-7.5. The Environmental Protection Agency (1976) recommends a $\mathrm{pH}$ range of 6.5-9.0 for protection of freshwater aquatic life. Neuse River $\mathrm{pH}$ values were below this range in approximately 50 percent of the samples. These low values indicate a slight acidity which is not likely to directly harm freshwater aquatic life, but may act synergistically with other materials, causing detrimental effects. The toxicity of lead to fish, for example, changes with $\mathrm{pH}$.

\section{Suspended sediment}

Sediment is the solid material of stream discharge. Sediment consists of any erodable material that is not in solution in the stream. This material includes soils, leaf litter and similar organic debris, sewage or industrial sludge, and particulate fallout from material suspended in the atmosphere. Nutrients, metals such as lead, and organic materials, including many pesticides, are readily sorbed by sediment particles.

Sediment is extremely important in the ecology of streams. Sediment provides animal habitats and nutrients to many organisms. Rapid changes in suspended sediment concentrations may choke fish or filter-feeding organisms. Suspended sediment also reduces light available to water-plants or algae. 
Sediment is often a problem for man. Reservoirs, locks, and navigation channels can be clogged with sediment. Sediment may also be a problem in fisheries, and industrial or domestic water use. Finally, high suspended sediment levels reduce aesthetic values of rivers and lakes.

At Clayton, unusually high sediment concentrations generally are associated with storms. Suspended sediment statistics are given in table 2 . Suspended sediment concentrations for a storm monitored at Clayton are shown in figure 9. In general, the change in suspended-sediment concentration with flood flows at Clayton is characterized by a rapid peaking of concentration at the beginning of a flood, followed by a recession. This flushing effect, in which sediment concentration on the rising phase of the streamflow hydrograph is greater than on the falling phase, is in part due to the decrease of the erosive action of streamflow during the recession. However, the availability of erodible material also plays an important role. A small storm may be sufficient to cleanse the stream of material immediately available for erosion. If another storm occurs soon after the first, suspended-sediment concentrations will be correspondingly lower. This may in fact be the relationship displayed in the double-peaked hydrograph of figure 9.

The recession in suspended-sediment concentration is exponential as illustrated by the curves shown in figure 9. Similar exponential declines during floods often characterize the concentrations of other materials associated with sediment. Stormwater runoff from urban areas is of ten heavily laden with sediment. This nonpoint source pollution is a growing problem in most urban areas (American Public Works Association, 1969).

Plots of suspended sediment concentration against discharge give the relation shown in figure 10 (Clayton) and figure 11 (Kinston). The correlation coefficient for the Clayton relation is high $(r=0.86)$ and the $F$ value indicates a significant (at the 95 percent probability level) relation of suspended-sediment concentration to discharge. However, the low correlation of the Kinston relation $(r=0.37)$ and the nearly constant suspended sediment concentrations observed there, suggest a relative independence of sediment concentration from discharge. A hysteresis effect in figure 10, caused by the suspended-sediment-concentration recession, is apparent for the plotted points of the flood of August 1974 (see fig. 9).

At Kinston, the apparent independence from discharge of suspended sediment concentrations is principally a result of the basin size and relief. The areal rainfall distribution over a large watershed is usually nonuniform. Consequently, although a heavy rainstorm at clayton may have a considerable impact on water quality, the effect will be dampened by the time the flood crest reaches Kinston. Water flowing past the Kinson station which came from a rainstorm above Clayton has been mixed with surface water from other tributaries. The lower stream bed slope at Kinston also plays an important role in the difference in suspended-sediment concentrations observed at the two stations. A lower slope reduces the river flow velocity, which in turn reduces the stream's sediment carrying capacity. 


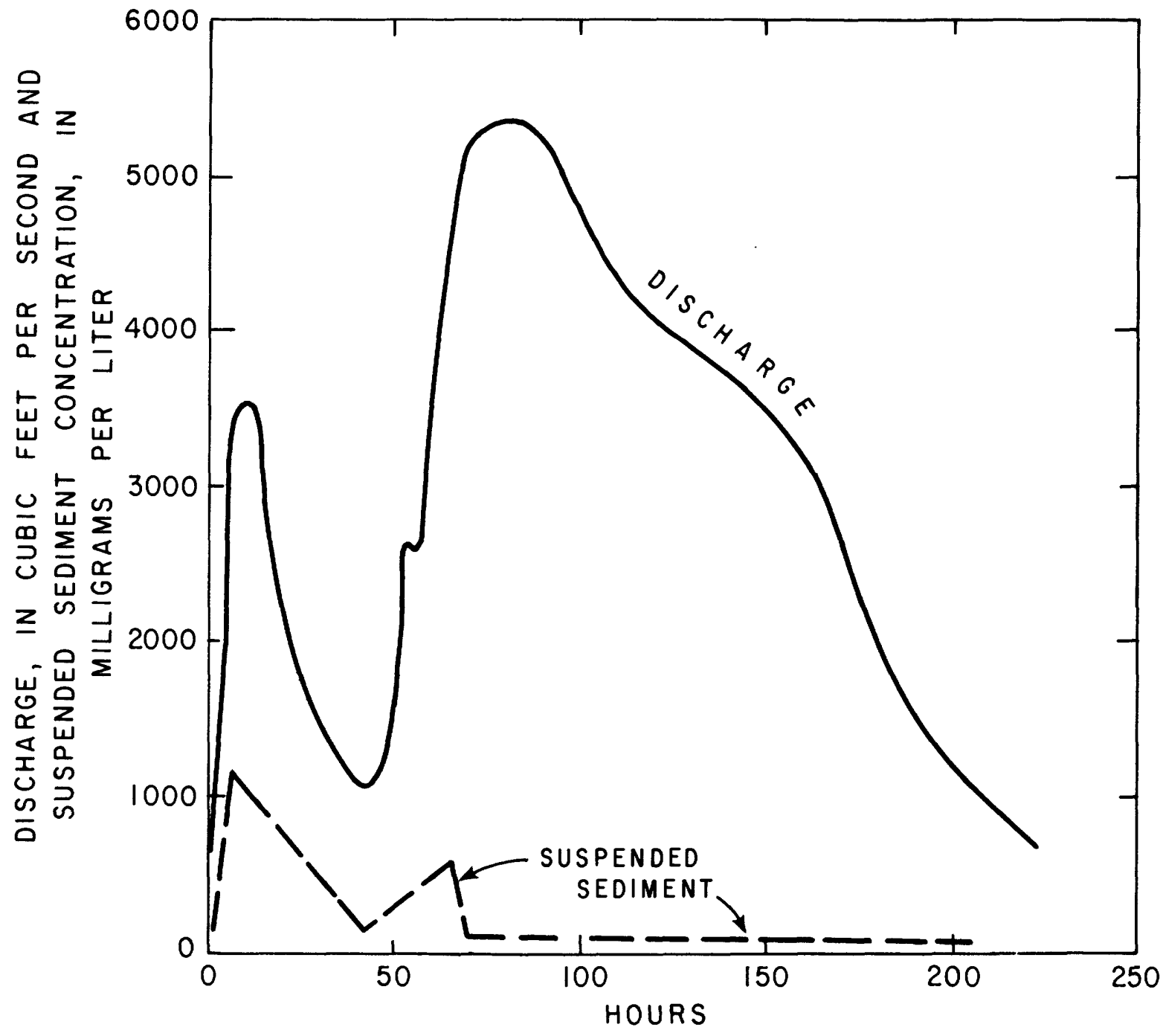

Figure 9.--Hydrograph showing relationship of discharge and suspendedsediment concentration for the storm of August 4, 1974, at Clayton. 


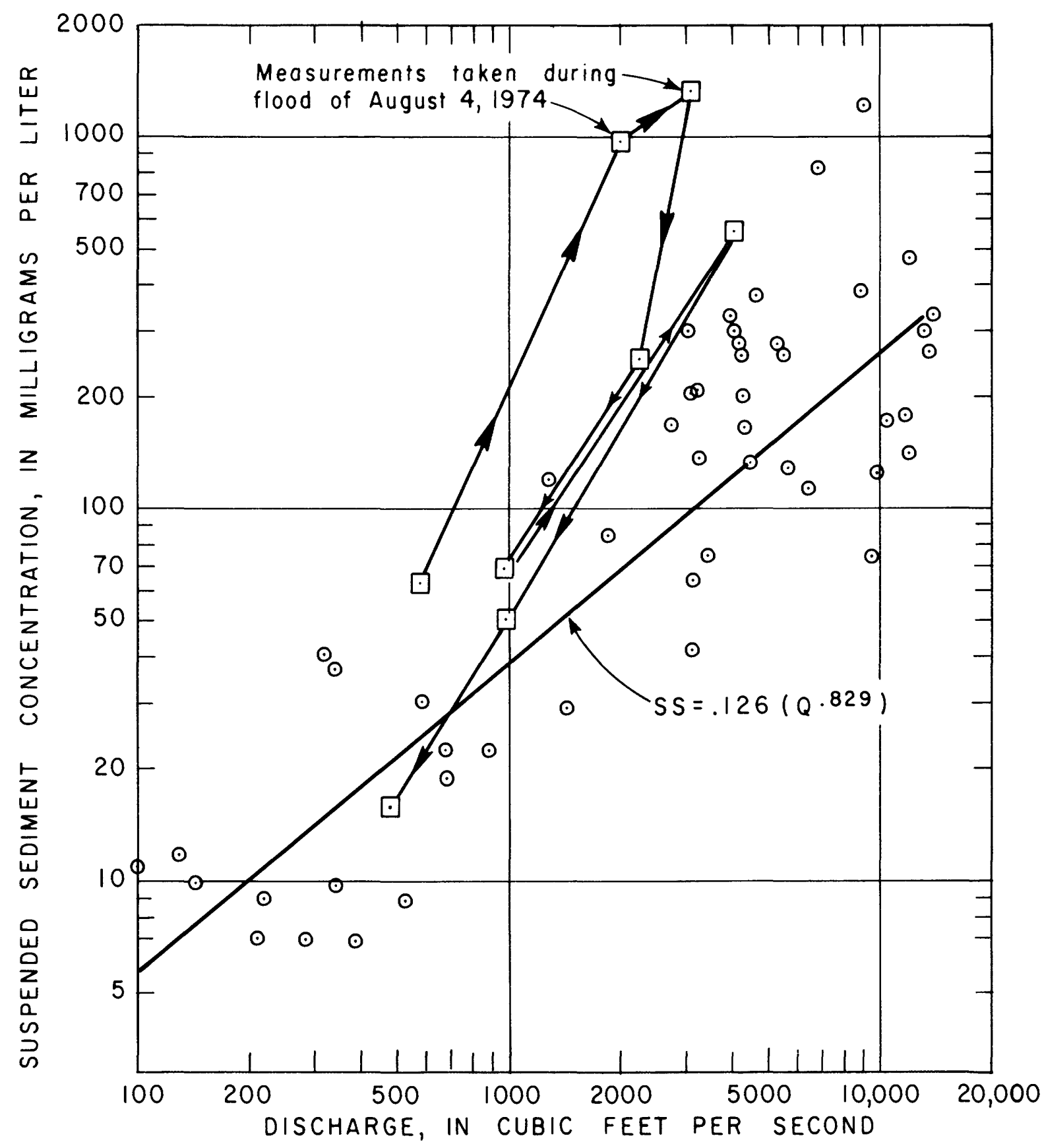

Figure 10.--Stream discharge (Q) versus suspended-sediment concentration (SS) for 1973-76, Neuse River at Clayton. 


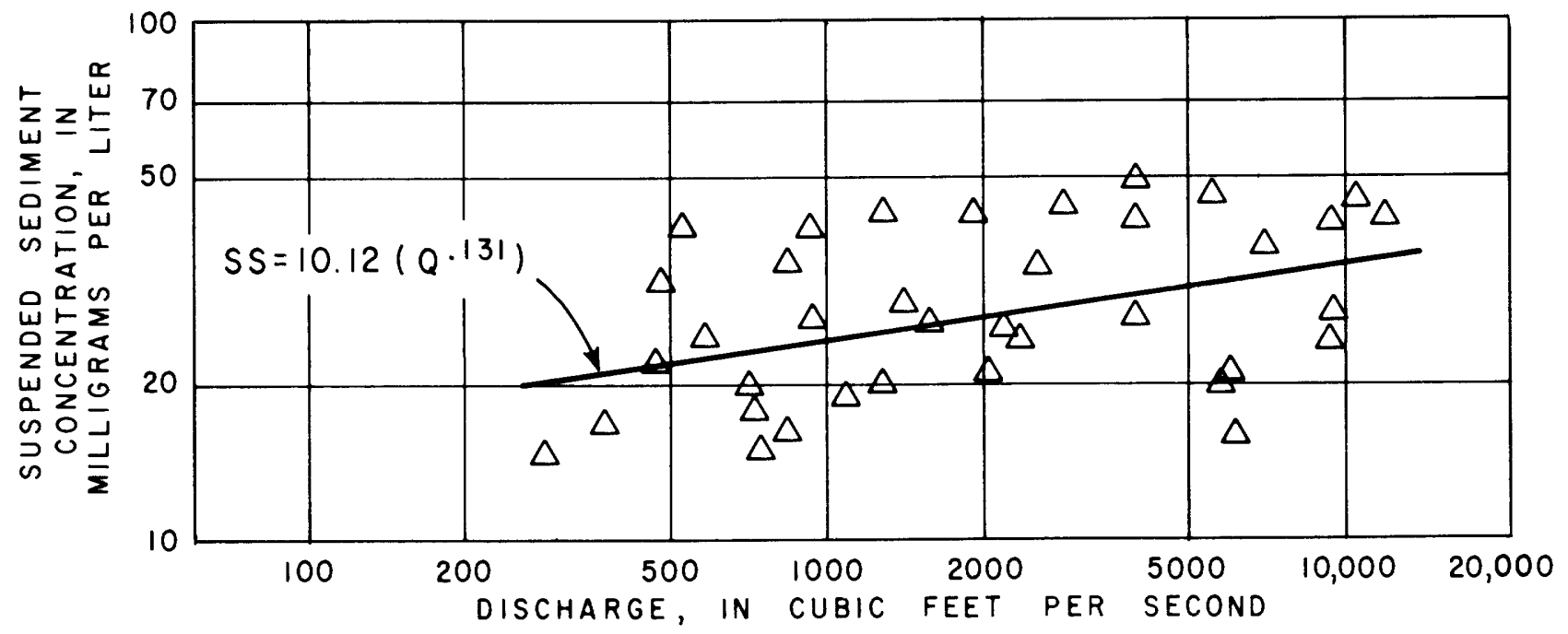

Figure 11.--Stream discharge (Q) versus suspended-sediment concentration (SS) for 1973-76, Neuse River at Kinston. 
Turbidity values are also lower at Kinston than at Clayton, corresponding primarily to the lower suspended sediment concentrations at Kinston. This difference between two stations in capacity to transmit light through water may be an important reason for the larger algal cell concentrations found at Kinston than at Clayton. (See Biological Characteristics). Turbidity statistics for both stations are given in table 2 .

Although environmental impacts of high suspended sediment concentrations are numerous, no national standards have been promulgated. However, some guidelines for turbidity are available (EPA, 1976). Turbidity levels at both stations are at satisfactory levels for use of the water in domestic supplies with standard treatment. Less demanding industrial uses, such as paper pulp processing, could use Neuse River water from either location without treatment.

The aesthetic problems of sediment are rarely addressed in water-quality standards or guidelines. The crystal-clear waters reported by early explorers of North Carolina (North Carolina Department of Natural Resources and Community Development, 1979), are now, for the most part, murky with suspended sediment. The full aesthetic impact of sediment on the Neuse River is undefinable.

\section{MAJOR DISSOLVED SUBSTANCES}

Mean values for all major dissolved substances characterize the Neuse River water at both Clayton and Kinston as chemically average or lower than average for natural surface waters of the United States (Todd, 1970). A summary of mean values for major dissolved materials and related statistics for the samples collected at both Neuse stations during the 1974-77 water years is given in table 3 .

In instances where criteria values for recommended maximum constituent concentrations for domestic use have been defined (EPA, 1976), Neuse River water at both stations meets the most stringent recommendations (table 3 ).

Cation-anion diagrams (Stiff, 1951) give a graphic representation of the ionic composition of water samples. Composite diagrams, each representing the mean of all samples taken in the 1974-77 water years, for both Neuse stations are shown in figure 12. The cation-anion diagrams for the two stations are quite similar. At both stations, sodium and potassium are the dominant cations, and bicarbonate is the dominant anion. The only sizable difference in ionic composition between the stations appears to be a higher overall concentration of sodium and potassium at Clayton.

Specific conductance, a measure of the ability of water to carry an electric current, gives an approximate expression of the amount of ionic material dissolved in water. Dissolved material concentrations are diluted by flood flows, so specific conductance usually varies inversely with discharge.

Specific conductance statistics given in table 3 , show Kinston to have lower values than Clayton, indicating an overall water-quality improvement in dissolved constituents downstream from the urbanized upper basin. A comparison 
Table 3.--A summary of statistics for major dissolved substances for samples collected from the Neuse River at Clayton and Kinston, 1974-77 water years

\begin{tabular}{|c|c|c|c|c|c|c|c|}
\hline \multirow[b]{3}{*}{$\begin{array}{c}\text { Constituent } \\
\mathrm{mg} / \mathrm{L}\end{array}$} & \multicolumn{3}{|c|}{ CLAYTON } & \multicolumn{3}{|c|}{ KINSTON } & \\
\hline & Mean & & & Mean & & & \multirow[b]{2}{*}{$\begin{array}{c}\text { Criteria } \\
(\mathrm{EPA}, 1976)\end{array}$} \\
\hline & $\begin{array}{l}95 \text { percent } \\
\text { confidence } \\
\text { limits }\end{array}$ & Range & $\begin{array}{c}\text { Number } \\
\text { of } \\
\text { samples }\end{array}$ & $\begin{array}{c}95 \text { percent } \\
\text { confidence } \\
\text { limits }\end{array}$ & Range & $\begin{array}{l}\text { Number } \\
\text { of } \\
\text { samples }\end{array}$ & \\
\hline \multirow{2}{*}{$\begin{array}{l}\text { Silica } \\
\left(\mathrm{SiO}_{2}\right)\end{array}$} & 12 & \multirow{2}{*}{$4.9-19$} & \multirow{2}{*}{48} & 9.3 & \multirow{2}{*}{$3.1-14$} & \multirow{2}{*}{45} & \multirow{2}{*}{-} \\
\hline & $10 \cdot 9-13$ & & & $8.6-10$ & & & \\
\hline \multirow{2}{*}{$\begin{array}{l}\text { Calcium } \\
\text { (Ca) }\end{array}$} & 6.1 & \multirow{2}{*}{$3 \cdot 3-12$} & \multirow{2}{*}{48} & 5.6 & \multirow{2}{*}{$3.2-8.8$} & \multirow{2}{*}{45} & \multirow{2}{*}{-} \\
\hline & $5.5-6.7$ & & & $5.2-6.0$ & & & \\
\hline \multirow{2}{*}{$\begin{array}{l}\text { Magnesium } \\
(\mathrm{Mg})\end{array}$} & 1.9 & \multirow{2}{*}{$0.9-3.3$} & \multirow{2}{*}{48} & 1.7 & \multirow{2}{*}{$1.1-2.5$} & \multirow{2}{*}{45} & \multirow{2}{*}{-} \\
\hline & $1.7-2.1$ & & & $1.6-1.8$ & & & \\
\hline \multirow{2}{*}{$\begin{array}{l}\text { Sodium } \\
\text { (Na) }\end{array}$} & 11 & \multirow{2}{*}{$2.6-37$} & \multirow{2}{*}{48} & 8.4 & \multirow{2}{*}{$3 \cdot 5-17$} & \multirow{2}{*}{45} & \multirow{2}{*}{-} \\
\hline & $9.1-14$ & & & $7.4-9.4$ & & & \\
\hline \multirow{2}{*}{$\begin{array}{l}\text { Potassium } \\
\text { (K) }\end{array}$} & 2.7 & \multirow{2}{*}{$1.5-6.4$} & \multirow{2}{*}{48} & 2.6 & \multirow{2}{*}{$1.7-4.0$} & & \\
\hline & $2.4-3.0$ & & & $2.4-2.8$ & & 45 & - \\
\hline Bicarbonate & 25 & 0 & 48 & 20 & 70 & 166 & \\
\hline$\left(\mathrm{HCO}_{3}\right)$ & $22-29$ & 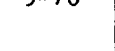 & 40 & $17-23$ & $1.0-40$ & 40 & - \\
\hline Sulfate & 9.8 & & & 10.2 & & & \\
\hline$\left(\mathrm{SO}_{4}\right)$ & $8.8-10.8$ & $6.3-24$ & 48 & $9.5-10.9$ & $7.2-15$ & 45 & $\begin{array}{l}\text { Upper limit for domestic } \\
\text { use: } 250 \mathrm{mg} / \mathrm{L}\end{array}$ \\
\hline Chloride & 12 & & & 8.9 & & & \\
\hline (C1) & $10-15$ & $2.7-41$ & 48 & $8.0-9.8$ & $3.6-17$ & 45 & $\begin{array}{l}\text { Upper limit for domestic } \\
\text { use: } 250 \mathrm{mg} / \mathrm{L}\end{array}$ \\
\hline Fluoride & 0.3 & & & 0.2 & & & \\
\hline (F) & $0.2-0.4$ & $0.1-0.8$ & 48 & $0.17-0.23$ & $0-0.5$ & 45 & - \\
\hline $\begin{array}{l}\text { Dissolved } \\
\text { Solids }\end{array}$ & 83 & & & 71 & & & \\
\hline $\begin{array}{l}\text { (Residue } \\
\text { at } 180^{\circ} \mathrm{C} \text { ) }\end{array}$ & $73-93$ & $34-190$ & 47 & $76-67$ & 39-99 & 45 & - \\
\hline Hardness & 23 & $13-44$ & 48 & 21 & $13-32$ & & \\
\hline (as $\mathrm{CaCO}_{3}$ ) & $21-25$ & $13-44$ & 48 & $20-22$ & $13-32$ & 45 & it water \\
\hline Specific & 120 & & & 97 & & & \\
\hline (micro-mhos) & $8-233$ & 4 & 92 & $34-160$ & -184 & 81 & - \\
\hline
\end{tabular}



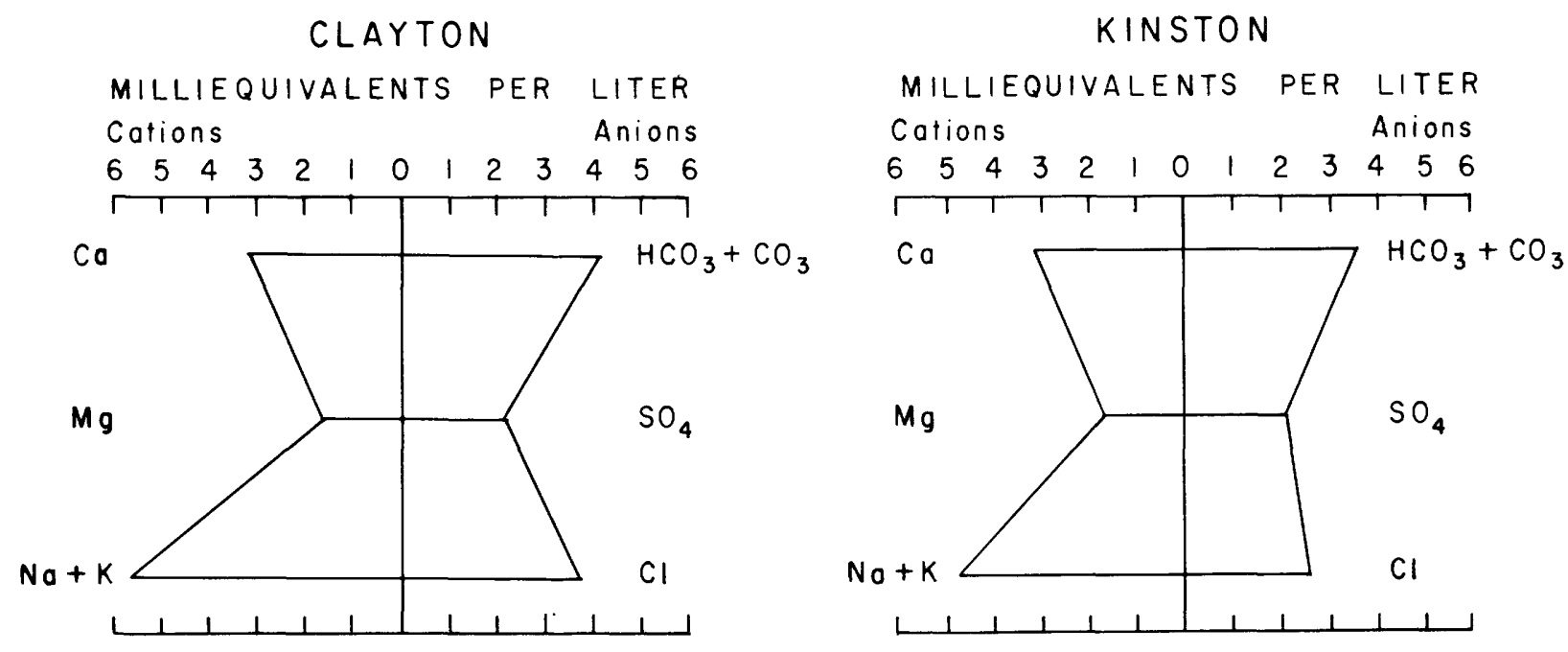

Figure 12.--Cation-anion diagrams for the Neuse River at Clayton and Kinston. Each diagram represents the mean of all samples taken in the 1974-77 water years. 
of the frequency distributions of specific conductance values for the two stations (fig. 13) illustrates this difference in water quality. Daily specific conductance values at clayton are greater than the maximum value recorded at Kinston 25 percent of the time. The lower conductance values observed at Kinston are primarily a result of dilution by streamflow from rural areas of the wastes originating from the urban areas upstream from clayton.

Conductivity is also correlatable with several specific ion concentrations. Correlations between specific conductance and dissolved constitutent concentrations are high, usually with coefficients ( $r$ ) above 0.80 . The regression lines for these relations, shown in figure 14 for Clayton and figure 15 for Kinston, can be used to predict concentrations of certain dissolved constituents if specific conductance is known. (See POLLUTION). Interestingly, the slopes of the regression lines drawn for Clayton data (fig. 14) are similar to those found for Kinston (fig. 15), an indication that the chemical quality of water at Kinston is much like that of Clayton.

Arithmetic plots of discharges versus dissolved constituent concentrations show a decrease in concentration with increased discharge. Power curves can be fitted to these plots and yield reasonably high correlation coefficients. Power curves have the general form:

$$
\mathrm{C}=\mathrm{bQ} \mathrm{Q}^{\mathrm{m}}
$$

or in logarithmic form:

$$
\ln C=\ln \left(b^{\mathrm{m}}\right)=\ln \mathrm{b}+\mathrm{m} \ln \mathrm{Q}
$$

where $\mathrm{C}$ is constituent concentration, Q vs discharge, $1 \mathrm{n} \mathrm{b}$ is the y-intercept, and $\mathrm{m}$ is the slope. This relation for the Neuse River is illustrated by the plot for dissolved solids shown in figure 16.

\section{TRACE ELEMENTS}

Minute concentrations of a variety of elements occur naturally in surface waters. Industrial and municipal effluents frequently contain metals in low concentrations. Certain trace elements such as mercury, lead, arsenic, selenium and cadmium can be highly toxic to both humans and wildlife. Even minute concentrations of these toxic substances are of concern because higher concentrations are frequent ly accumulated in aquatic organisms feeding in contaminated waters. Other elements, including iron and manganese, may cause undesirable water taste, or produce scaling, particularly in hot water systems.

A summary of trace element analyses from 1974-77 (table 4) indicates low level contamination of the Neuse River at both Clayton and Kinston. However, only iron and manganese concentrations are consistently higher than criterion levels suggested for domestic water supply (EPA, 1976). Iron concentrations are higher than the criterion level in 28 percent of the samples taken at clayton and 39 percent at Kinston. Manganese concentrations are higher than the criterion level in all samples taken at clayton and in 88 percent of the samples 


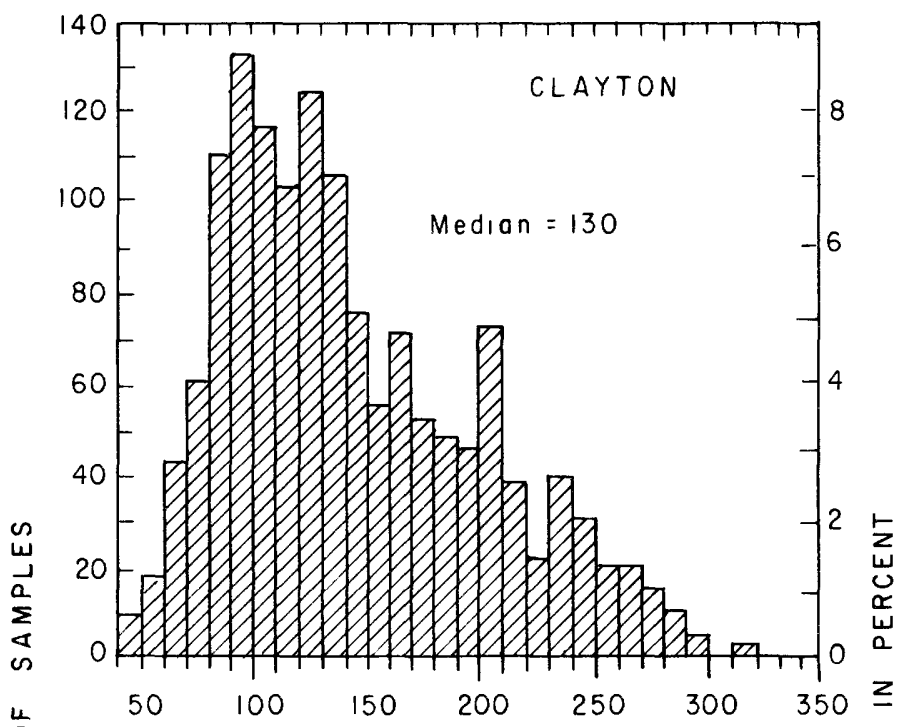

แ

崩

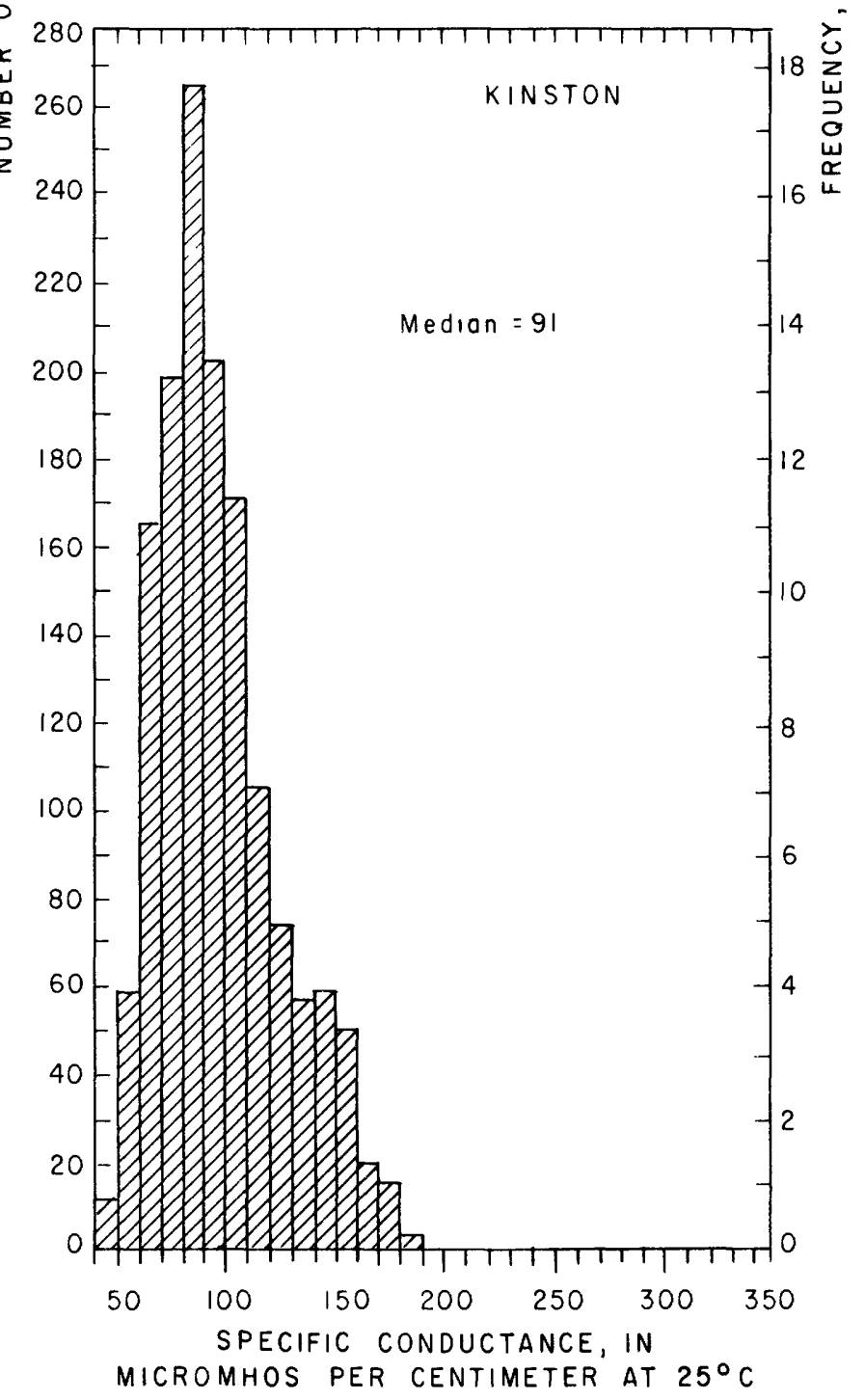

Figure 13.--Frequency distribution of daily specific conductance values, Neuse River at Clayton and Kinston, 1974-77 water years. 

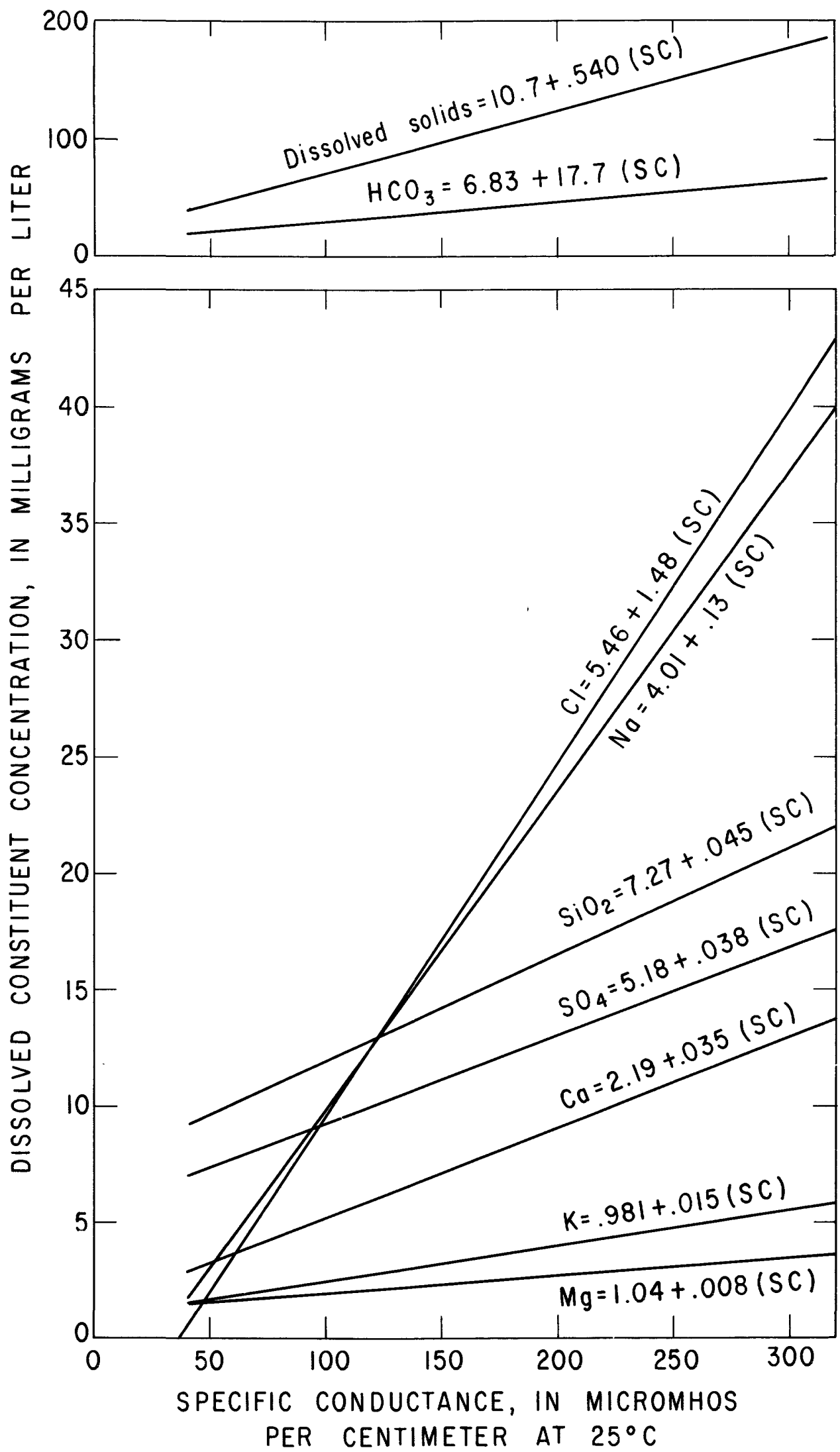

Figure 14.--Regression 1ines of dissolved-constituent concentration versus the known range of specific conductance, Neuse River at Clayton, 1974-77 water years. 


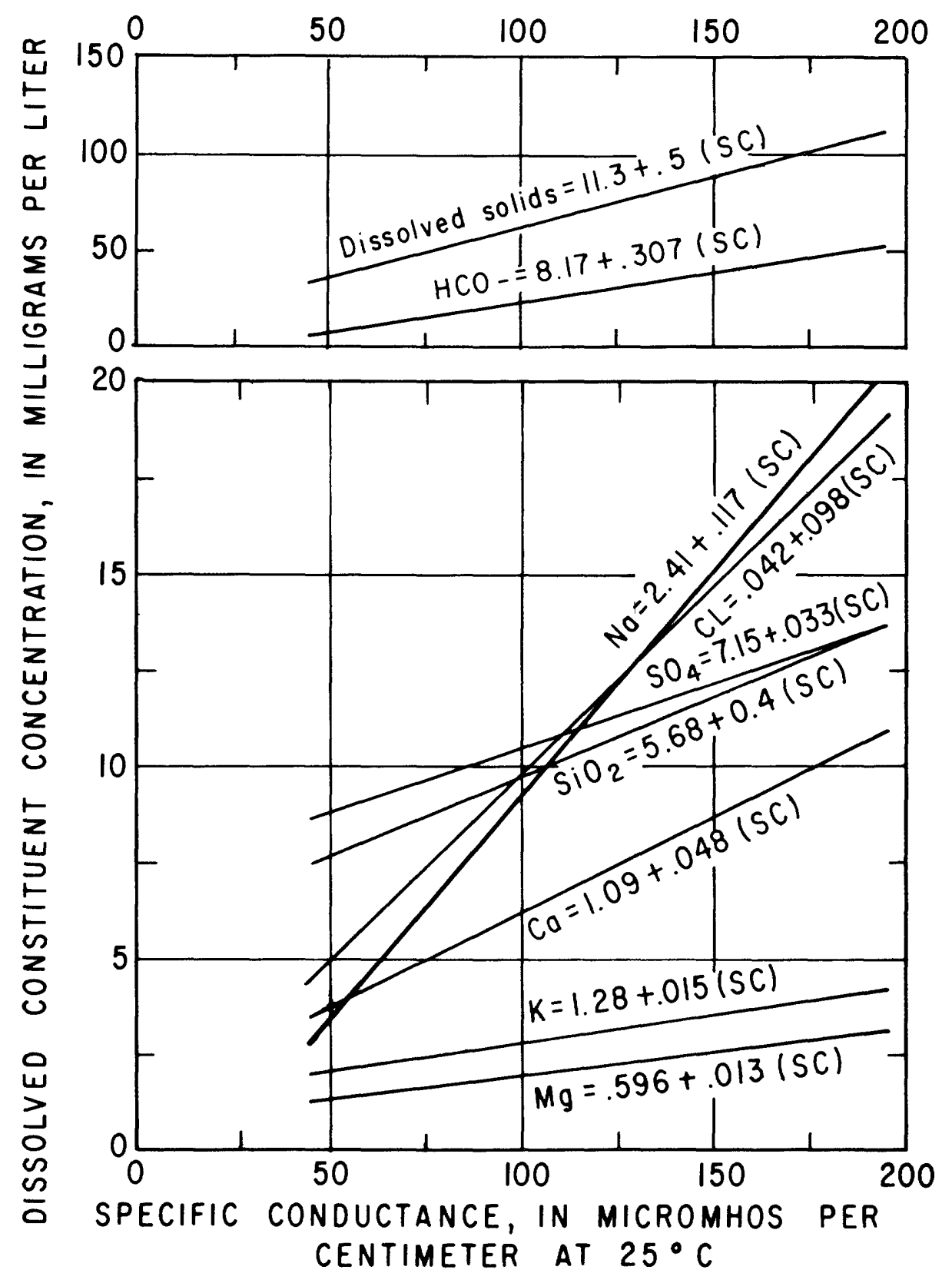

Figure 15.--Regression lines of dissolved-constituent concentration versus the known range of specific conductance, Neuse River at Kinston, 1974-77 water years. 


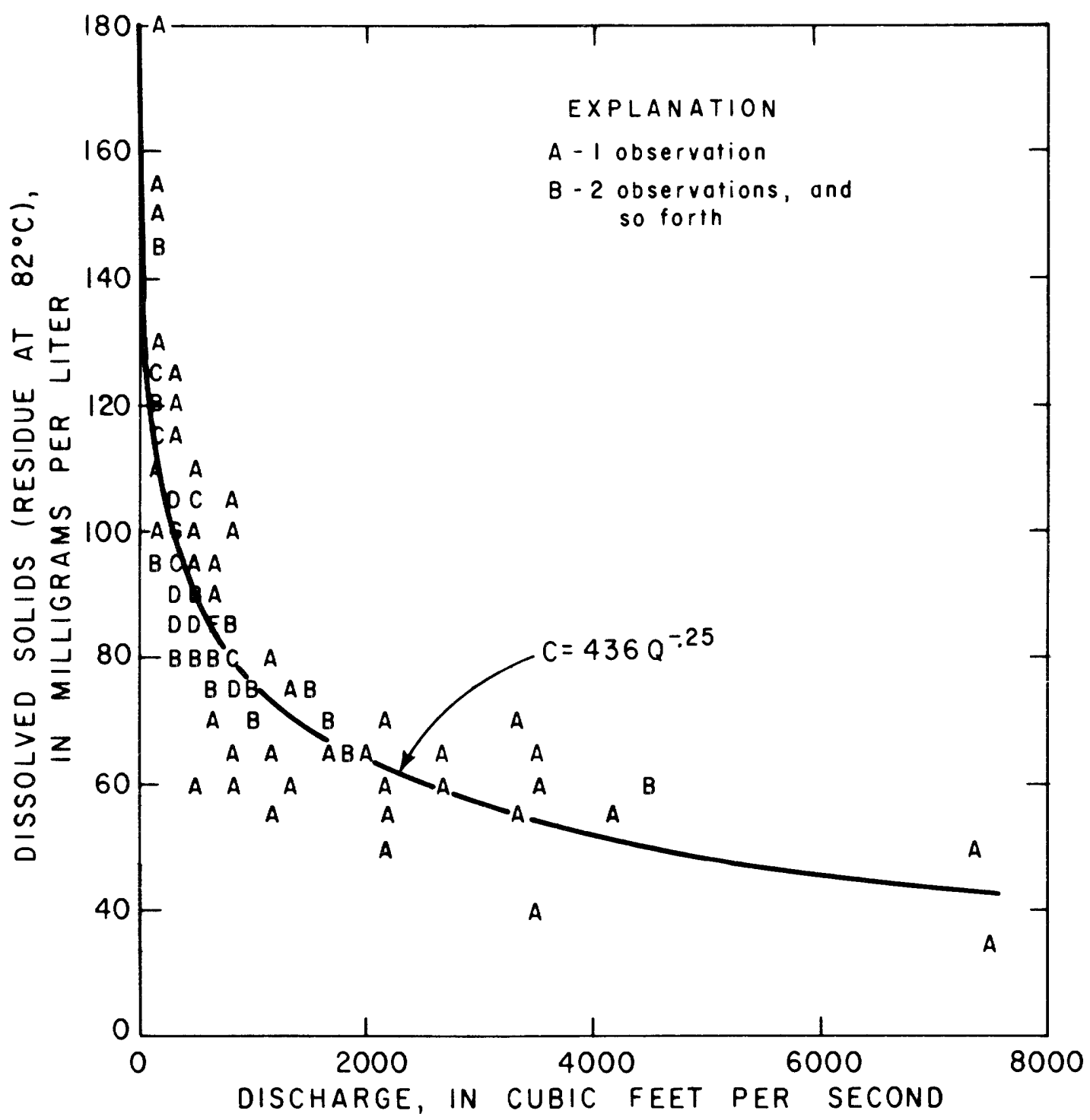

Figure 16.--Relation of discharge and dissolved-solids concentration of the Neuse River at Clayton, 1956-67 water years. 
Table 4.--A summary of total trace-element concentration statistics for the Neuse River at Clayton and Kinston, 1974-77 water years

\begin{tabular}{|c|c|c|c|c|c|c|c|}
\hline \multirow[b]{3}{*}{$\begin{array}{l}\text { Trace } \\
\text { Element } \\
\left(\mu_{\mathrm{g} / \mathrm{L})}\right.\end{array}$} & \multicolumn{3}{|c|}{ CLAYTON } & \multicolumn{3}{|c|}{ KINSTON } & \multirow[b]{3}{*}{$\begin{array}{c}\text { Criteria } \\
(\mathrm{EPA}, 1976)\end{array}$} \\
\hline & Mean & \multirow[b]{2}{*}{ Range } & \multirow[b]{2}{*}{$\begin{array}{l}\text { Number } \\
\text { of } \\
\text { samples }\end{array}$} & Mean & \multirow[b]{2}{*}{ Range } & \multirow[b]{2}{*}{$\begin{array}{l}\text { Number } \\
\text { of } \\
\text { samples }\end{array}$} & \\
\hline & $\begin{array}{l}95 \text { percent } \\
\text { conf idence } \\
\text { limits }\end{array}$ & & & $\begin{array}{c}95 \text { percent } \\
\text { confidence } \\
\text { limits } \\
\end{array}$ & & & \\
\hline \multirow{2}{*}{$\begin{array}{l}\text { Arsenic } \\
\text { (As) }\end{array}$} & 5.1 & \multirow{2}{*}{$0-30$} & \multirow{2}{*}{22} & 4.8 & \multirow{2}{*}{$0-50$} & \multirow{2}{*}{23} & \multirow{2}{*}{$\begin{array}{l}\text { Upper limit for domestic } \\
\text { water supply: } 50 \mathrm{\mu g} / \mathrm{L}\end{array}$} \\
\hline & $2-8.2$ & & & $-0.9-10.5$ & & & \\
\hline \multirow{2}{*}{$\begin{array}{l}\text { Cadmium } \\
\text { (Cd) }\end{array}$} & 7.9 & \multirow{2}{*}{$0-50$} & \multirow{2}{*}{23} & 5 & \multirow{2}{*}{$0-50$} & \multirow{2}{*}{24} & \multirow{2}{*}{$\begin{array}{l}\text { Upper limit for domestic } \\
\text { water supply: } 10 \mu \mathrm{g} / \mathrm{L} \text {, } \\
\text { for fish: } 4 \mathrm{\mu g} / \mathrm{L}\end{array}$} \\
\hline & $0.7-15$ & & & $-1 \cdot 1-11$ & & & \\
\hline \multirow{2}{*}{$\begin{array}{l}\text { Cobalt } \\
(\mathrm{Co})\end{array}$} & 14 & \multirow[b]{2}{*}{$0-100$} & \multirow[b]{2}{*}{21} & 12 & \multirow[b]{2}{*}{$0-100$} & \multirow[b]{2}{*}{23} & \multirow[b]{2}{*}{-} \\
\hline & $1.5-27$ & & & $-1.7-26$ & & & \\
\hline \multirow{2}{*}{$\begin{array}{l}\text { Copper } \\
\text { (Cu) }\end{array}$} & 17 & \multirow{2}{*}{$2-70$} & \multirow{2}{*}{38} & 9.3 & \multirow{2}{*}{$2-40$} & \multirow{2}{*}{24} & \multirow{2}{*}{$\begin{array}{l}\text { Upper limit for domestic } \\
\text { water supply: } 1000 \mathrm{\mu g} / \mathrm{L}\end{array}$} \\
\hline & $12-22$ & & & $5-14$ & & & \\
\hline \multirow{2}{*}{$\begin{array}{l}\text { Iron } \\
(\mathrm{Fe})\end{array}$} & 320 & & 34 & 290 & & & Upper 1 imit for domestic \\
\hline & $280-360$ & $110-950$ & 34 & $240-340$ & $90-480$ & 22 & water supply: $300 \mu \mathrm{g} / \mathrm{L}$ \\
\hline Lead & 40 & $2-500$ & 38 & 24 & & 24 & Upper limit for domestic \\
\hline$(\mathrm{Pb})$ & $13-67$ & $2-300$ & 38 & $38-10$ & $0-100$ & 24 & water supply: $50 \mu \mathrm{g} / \mathrm{L}$ \\
\hline Manganese & 430 & $70-2200$ & 22 & 120 & & & Upper limit for domestic \\
\hline (Mn) & $190-670$ & $10-2200$ & 22 & $80-170$ & $20-450$ & 23 & water supply: $50 \mu \mathrm{g} / \mathrm{L}$ \\
\hline Mercury & 0.3 & $0-0,5$ & 29 & 0.2 & $0-2 ?$ & 22 & Upper limit for domestic \\
\hline ( $\mathrm{Hg})$ & $0.2-0.4$ & 0.0 .0 & 23 & $0-0.4$ & $0-2.2$ & 22 & for fish: $0.05 \mu \mathrm{g} / \mathrm{L}$ \\
\hline Selenium & 5.4 & $0-12$ & 19 & 0.6 & 0 & 21 & Upper IImit for domestic \\
\hline (Se) & $3.6-7.2$ & $0-12$ & 19 & $-0.1-1.3$ & .0 & 21 & water supply: $10 \mu \mathrm{g} / \mathrm{L}$ \\
\hline $\mathrm{Z}$ Inc & 76 & $0-1400$ & 38 & 30 & $4=1<0$ & 24 & Upper limit for domestic \\
\hline$(\mathrm{Zn})$ & $3 \cdot 9-148$ & $0-1400$ & 50 & $17-44$ & $4-140$ & 24 & water supply: $5000 \mu \mathrm{g} / \mathrm{L}$ \\
\hline
\end{tabular}


collected at Kinston. The geology of the region is the primary cause for these high iron and manganese concentrations.

Other trace element concentrations periodically rise above the EPA (1976) domestic raw water supply criteria levels. Cadmium concentrations were above the criterion level for domestic water supply in 22 percent of the Clayton samples and 17 percent of the Kinston samples. Concentrations in 15 percent of the Clayton selenium analyses, 25 percent of Clayton lead analyses, and 20 percent of Kinston lead concentrations were also above domestic water supply criteria levels.

Wilder and Simmons (1978) reported a strong correlation between suspended sediment concentrations and total concentrations of lead and manganese for the Neuse River at Clayton. Relations of this kind demonstrate the role of sediment in controlling surface-water metal concentration. Sediments effectively remove dissolved metals from the water of rivers by adsorption of the metals onto the sediment particles. However, if the supply of dissolved metals in the river is reduced, metals are released from the sediments in order to maintain chemical equilibrium (Wershaw, 1976).

Overall, ambient concentrations for toxic elements in the Neuse Rj.ver at both stations are low. However, little is known about toxic element concentrations in bottom sediments or in aquatic organisms found in the Neuse River.

\section{NUTRIENTS}

Carbon, nitrogen and phosphorus are primary chemical elements required by algae for growth. These nutrients are therefore of primary interest in identifying causes of nuisance growths or blooms of algae.

The enrichment of a body of water with nutrients, the process of eutrophication, is normally associated with increases in algal populations. The accumulation of organic matter caused by growth and decomposition of algae in turn provides habitats and ample food supplies for bacteria and other aquatic organisms. Increased biological respiration from algae, and from organisms associated with the algae, causes an increased oxygen demand which reduces available dissolved oxygen. These effects are usually most pronounced in lakes and estuaries, where accumulation of nutrients may result in particularly high concentrations of algae.

The U.S. Geological Survey has periodically measured total and dissolved organic carbon, total and dissolved organic and ammonia nitrogen, dissolved orthophosphate and total phosphorus at both Neuse stations since 1973 . Measurements of total phosphate and nitrates are also available for certain periods previous to the more intensive sampling program begun in 1973 . Table 5 is a summary of nutrient analyses. 
Table 5.--A summary of nutrient statistics for samples of the Neuse River at Clayton and Kinston, 1974-77 water years. All values are in milligrams per liter

\begin{tabular}{|c|c|c|c|c|c|c|}
\hline \multirow[b]{3}{*}{ Parameter } & \multicolumn{3}{|c|}{ CLAYTON } & \multicolumn{3}{|c|}{ KINSTON } \\
\hline & Mean & \multirow[b]{2}{*}{ Range } & \multirow[b]{2}{*}{$\begin{array}{c}\text { Number } \\
\text { of } \\
\text { samples }\end{array}$} & Mean & \multirow[b]{2}{*}{ Range } & \multirow[b]{2}{*}{$\begin{array}{l}\text { Number } \\
\text { of } \\
\text { samples }\end{array}$} \\
\hline & $\begin{array}{c}95 \text { percent } \\
\text { confidence } \\
1 \text { imits }\end{array}$ & & & $\begin{array}{c}95 \text { percent } \\
\text { confidence } \\
\text { limits }\end{array}$ & & \\
\hline \multirow{2}{*}{$\begin{array}{l}\text { Total } \\
\text { organic } \\
\text { carbon }\end{array}$} & 14 & \multirow{2}{*}{$5-58$} & \multirow{2}{*}{34} & 12 & \multirow{2}{*}{$4 \cdot 1-27$} & \multirow{2}{*}{20} \\
\hline & $10.2-18$ & & & $9.1-15$ & & \\
\hline \multirow{2}{*}{$\begin{array}{l}\text { Dissolved } \\
\text { organic } \\
\text { carbon }\end{array}$} & 9.2 & \multirow{2}{*}{$2.8-20$} & \multirow{2}{*}{39} & 12 & \multirow{2}{*}{$1-19$} & \multirow{2}{*}{12} \\
\hline & $8-10.4$ & & & $8.8-15.2$ & & \\
\hline \multirow{2}{*}{$\begin{array}{c}\text { Total } \\
\text { ammonia } \\
\text { nitrogen } \\
\text { (as N) }\end{array}$} & .51 & \multirow{2}{*}{$0-1.9$} & \multirow{2}{*}{43} & .07 & \multirow{2}{*}{$.02-.27$} & \multirow[b]{2}{*}{13} \\
\hline & $.3-.7$ & & & $.03-.11$ & & \\
\hline \multirow{2}{*}{$\begin{array}{c}\text { Dissolved } \\
\text { ammonia } \\
\text { nitrogen } \\
\text { (as N) }\end{array}$} & .4 & \multirow[b]{2}{*}{$0-1.7$} & \multirow[b]{2}{*}{39} & .05 & \multirow{2}{*}{$0-.16$} & \multirow[b]{2}{*}{11} \\
\hline & $.3-.5$ & & & $.04-.06$ & & \\
\hline \multirow{2}{*}{$\begin{array}{c}\text { Dissolved } \\
\text { ammonia } \\
\text { nitrogen } \\
\text { (as } \mathrm{NH}_{4} \text { ) }\end{array}$} & .52 & \multirow[b]{2}{*}{$0-2.2$} & \multirow[b]{2}{*}{39} & .06 & & \\
\hline & $.3-.7$ & & & $.01-.11$ & $0-.21$ & 11 \\
\hline $\begin{array}{c}\text { Total } \\
\text { organic }\end{array}$ & .84 & & & .66 & & \\
\hline $\begin{array}{c}\text { nitrogen } \\
\text { (as N) }\end{array}$ & $.7-1$ & $0-3.4$ & 43 & $.50-.82$ & $.06-1.1$ & 13 \\
\hline $\begin{array}{c}\text { Dissolved } \\
\text { organic }\end{array}$ & .52 & & & .52 & & \\
\hline $\begin{array}{c}\text { nitrogen } \\
\text { (as N) }\end{array}$ & $.4-.6$ & $.16-1.3$ & 39 & $.61-.43$ & $.35-.76$ & 11 \\
\hline $\begin{array}{c}\text { Total } \\
\text { nitrite }+\end{array}$ & .92 & & & .48 & & \\
\hline $\begin{array}{l}\text { nitrate } \\
(\text { as N) }\end{array}$ & $1.2-.7$ & $.08-4.5$ & 44 & $.56-.40$ & $0-1.1$ & 47 \\
\hline $\begin{array}{c}\text { Tota1 } \\
\text { Kjeldah1 }\end{array}$ & 1.4 & & & .79 & & \\
\hline $\begin{array}{c}\text { nitrogen } \\
(\text { as } \mathrm{N})\end{array}$ & $1.1-1.7$ & $.06-4.9$ & 44 & $.70-.88$ & $.1-1.4$ & 47 \\
\hline Total & 2.4 & & & 1.3 & & \\
\hline$($ as N) & $2 .-2.8$ & $.33-6.1$ & 44 & $1.2-1.4$ & $64-2.1$ & 47 \\
\hline $\begin{array}{c}\text { Dissolved } \\
\text { ortho- }\end{array}$ & 1.4 & & & .28 & & \\
\hline $\begin{array}{l}\text { phosphate } \\
\left(\text { as } \mathrm{PO}_{4}\right)\end{array}$ & $.8-2$ & $0-8$ & 42 & $.17-.39$ & $.06-.55$ & 12 \\
\hline Total & .71 & & & .23 & & \\
\hline $\begin{array}{l}\text { phosphorus } \\
\text { (as P) }\end{array}$ & $.5-.9$ & $.07-2.7$ & 43 & $.21-.25$ & $.07-.38$ & 47 \\
\hline
\end{tabular}




\section{Carbon}

A range of 5 to $15 \mathrm{mg} / \mathrm{L}$ TOC (total organic carbon) is characteristic of unpolluted streams in this region (Weiss and others, 1973). One-fourth of the samples collected at Clayton and half of the samples collected at Kinston during the 1974-77 water years, have TOC values of $15 \mathrm{mg} / \mathrm{L}$ or greater. Dissolved organic carbon concentrations are approximately 85 percent that of the total organic carbon concentrations. These results indicate that the Neuse River at both Clayton and Kinston is moderately enriched with organic carbon, often with concentrations greater than Weiss' upper limit for unpolluted streams. Furthermore, there is no distinct difference between the distribution of TOC concentrations at Clayton and that at Kinston.

There is some evidence that total organic carbon concentrations in the Neuse River have decreased significantly since 1976. This improvement in water quality corresponds to the activation of the Neuse River Wastewater Treatment Plant in December 1976. (See Water Use and Waste Disposa1).

\section{Nitrogen}

Ammonia is a reduced form of nitrogen that is oxidized by aquatic aerobic bacteria to nitrite and nitrate. In addition, ammonia nitrogen is utilized by algae in preference to these other forms of nitrogen. Because of the transiency of ammonia nitrogen, the presence of substantial concentrations (greater than $0.5 \mathrm{mg} / \mathrm{L}$ as $\mathrm{N}$ ) is considered indicative of contamination by human or animal wastes, or fertilizer (Weiss and others, 1973). At Clayton 27 percent of the samples had total and dissolved ammonia nitrogen concentrations greater than $0.5 \mathrm{mg} / \mathrm{L}$ (as $\mathrm{N}$ ), while at Kinston all samples had less than $0.2 \mathrm{mg} / \mathrm{L}$ total and dissolved ammonia nitrogen. The high ammonia levels at clayton are probably due to upstream point-source nutrient inputs, including waste treatment plants for Raleigh and Durham.

The low total ammonia concentrations measured at Kinston are due in part to the natural in-stream oxidation of ammonia to nitrite and nitrate. However, total nitrite plus nitrate concentrations measured at Kinston are also lower than clayton values. These lower concentrations reflect, to a large extent, the uptake of the nitrogen by algae (see Biological Characteristics). The frequency histograms given in figure 17 illustrate the reduced Kinston levels.

A value of $0.5 \mathrm{mg} / \mathrm{L}$ total nitrogen (as $\mathrm{N}$ ) has been suggested by the National Technical Advisory Committee (1968) as a threshold value for algal growth in impounded waters. The total nitrogen levels at both Neuse stations (median values of $2.0 \mathrm{mg} / \mathrm{L}$ at Clayton, and $1.4 \mathrm{mg} / \mathrm{L}$ at Kinston) are usually higher than this threshold (fig. 18).

Mean annual nitrogen $\left(\mathrm{NO}_{2}+\mathrm{NO}_{3}\right.$, and ammonia + organic) concentrations at Clayton have increased significantly since the activation of the Neuse River Wastewater Treatment plant in December 1976. No significant changes in nitrogen concentrations are apparent at Kinston for this period. The increases 


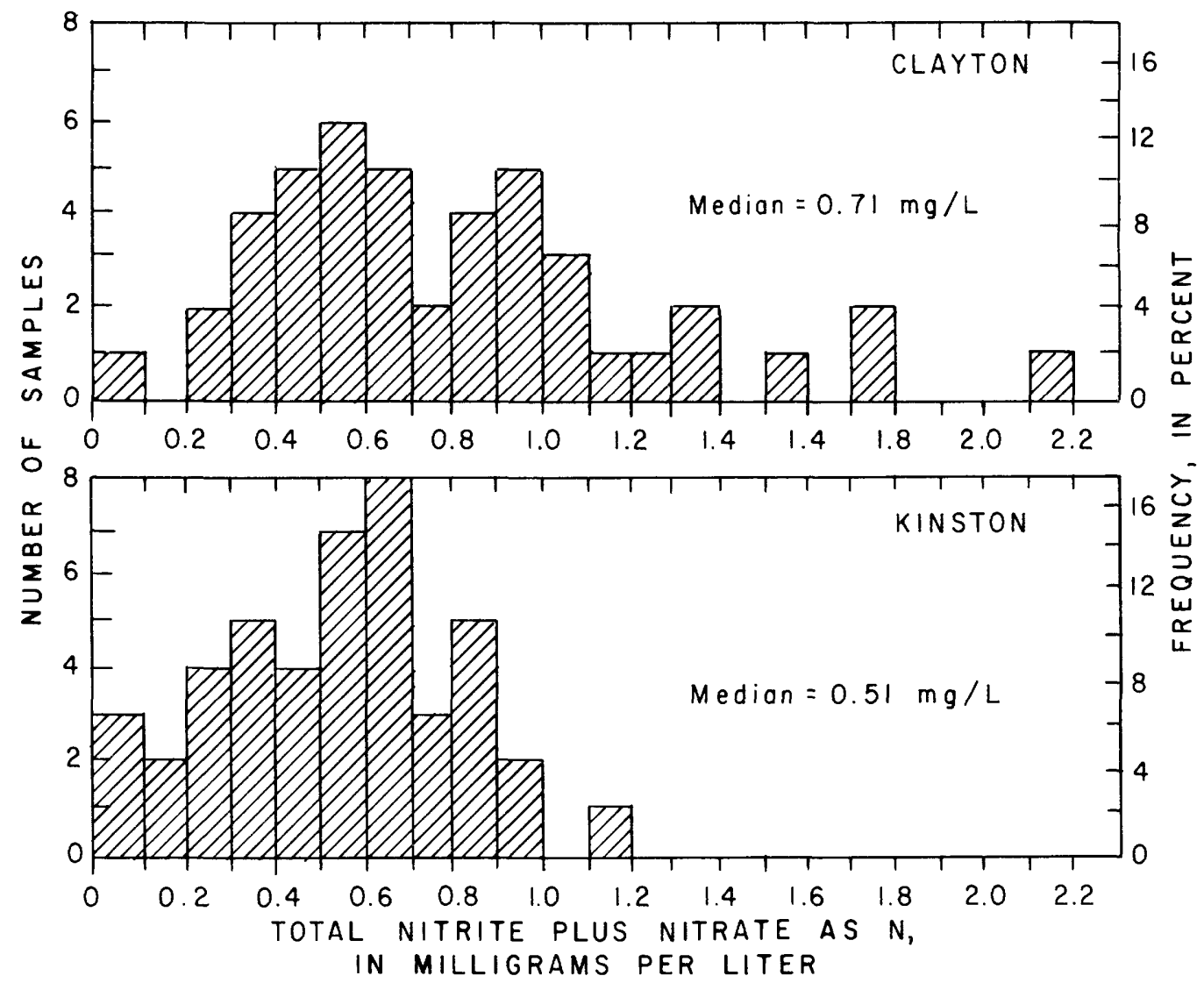

Figure 17.--Frequency histograms for total nitrite plus nitrate (as N) of the Neuse River at Clayton and Kinston, 1974-77 water years. 


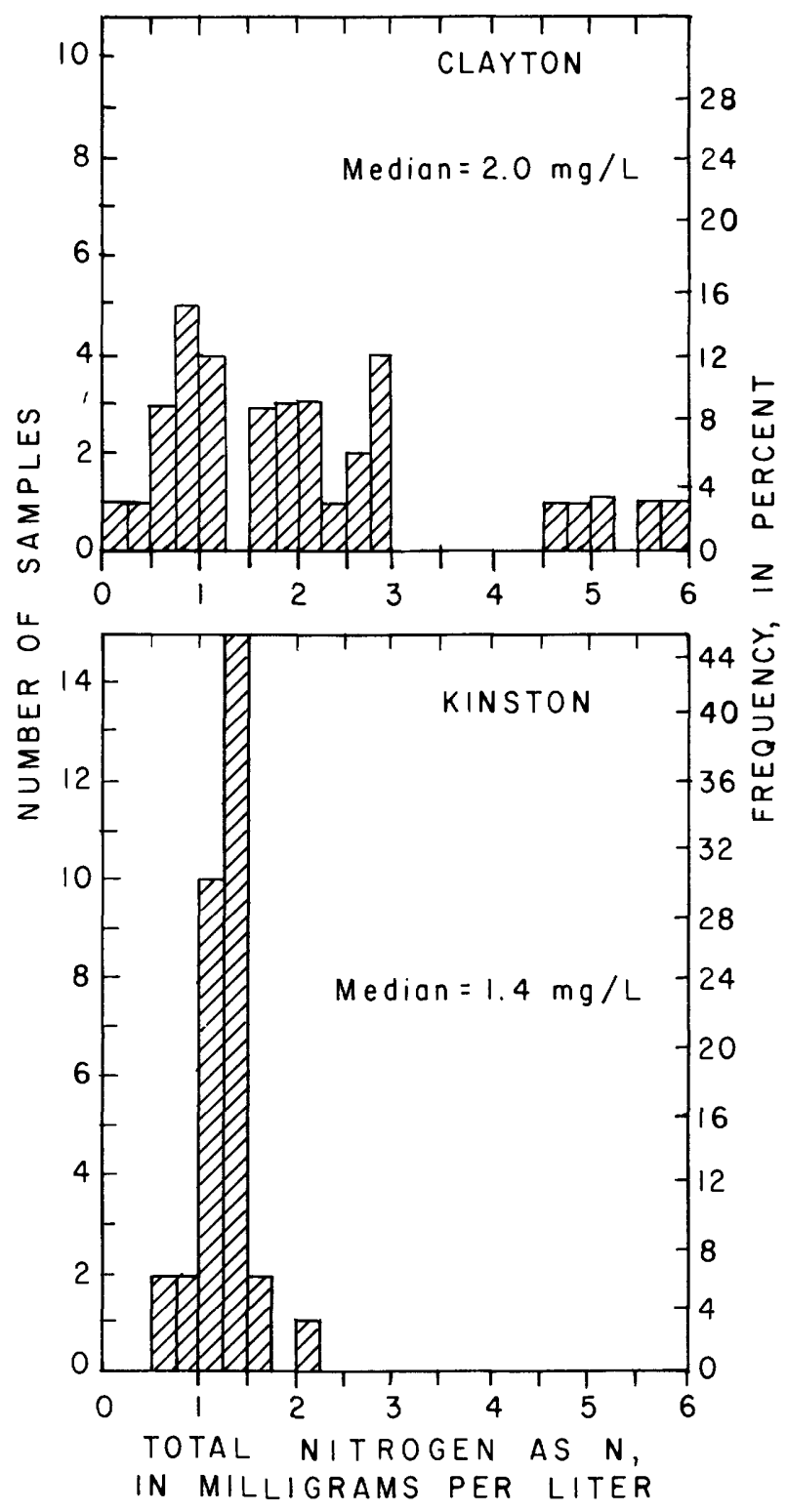

Figure 18.--Frequency histograms for total nitrogen (as N) of the Neuse River at Clayton and Kinston, 1974-77 water years. 
evident at Clayton are probably a result of the location of the new plant closer to the Clayton station.

\section{Phosphorus}

Phosphorus is the other major nutrient essential to algal growth. The National Technical Advisory Committee (1968) cites $0.05 \mathrm{mg} / \mathrm{L}$ total phosphorus (as P) as the limiting level for algal growth for streams entering impoundments. Total phosphorus levels at both Neuse stations are almost always greater than this limiting concentration ( $f$ ig. 19) with median values at 0.56 $\mathrm{mg} / \mathrm{L}$ at Clayton and $0.23 \mathrm{mg} / \mathrm{L}$ at Kinston.

Mean annual total phosphorus concentrations at Clayton have increased significantly (two-tailed t-test of means, at a probability level of 0.05 ) since the relocation of the wastewater treatment plant closer to the station. No significant recent changes in phosphorus concentrations are evident at Kinston.

\section{Nutrient relations}

The total nitrogen/total phosphorus ratio is a means used to evaluate nutrient conditions in surface waters. The National Technical Advisory Committee (1968) cites a ratio of $10: 1$ as indicative of normal conditions in lakes. A similar ratio is reported by Weiss and Kuenzler (1976) for North Carolina lakes. The ratio of median total nitrogen to median total phosphorus is 3.5:1 at Clayton and $6: 1$ at Kinston. These results may indicate a potential for excess algae growth at both stations, however, it is difficult to compare Neuse River nutrient concentrations to conditions measured for lakes.

The amounts of nitrogen and phosphorus in the Neuse River are ample to supply algal growth. The reach of the Neuse above Clayton is particularly rich in these nutrients. Not surprisingly, much concern has been voiced over projected nutrient levels in the Falls reservoir (U.S. Army Corps of Engineers, 1973) that will be located along the upper reach of the Neuse downstream from the Durham wastewater treatment plant outfall. Construction of the Falls reservoir has coincided with the growth of algal blooms downstream from the dam site and upstream from Clayton. Construction has increased sediment loads below the dam site, in turn increasing the resolution of nutrients associated with sediment. High nutrient levels, combined with warm summer temperatures, and low streamflow have promoted the growth of algal blooms.

Reduced nutrient levels measured downsteam at Kinston coincide with considerable in-stream algal growth that has utlilized some of the nutrients in the water (See Biological Characteristics). Currently algal growths are not a major concern in the Neuse River estuary, however, future problems are projected if increased nutrient loading exceeds the estuary's ability to assimilate nutrients without excess algal growth (Hobbie and Smith, 1975). 


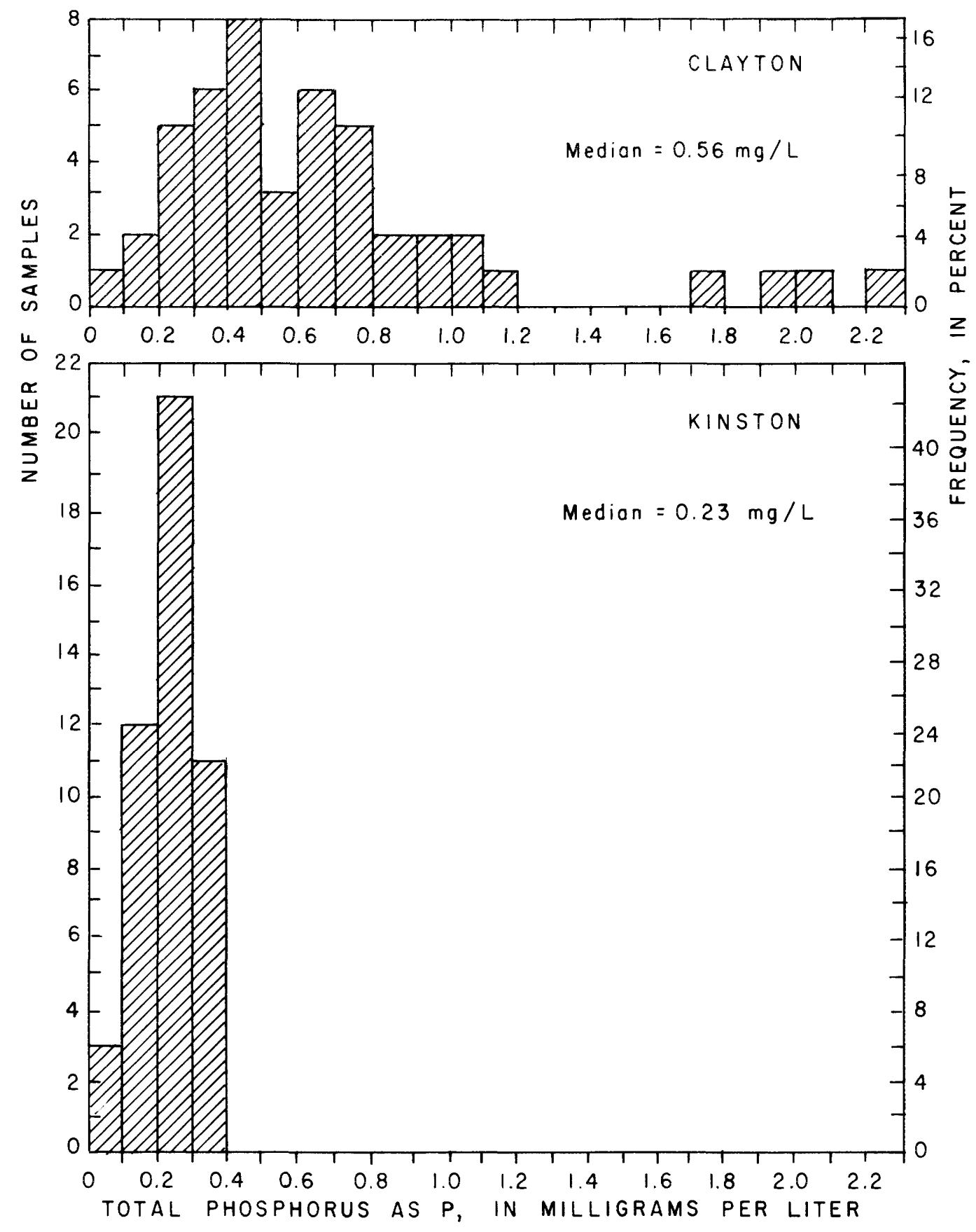

Figure 19.--Frequency histograms for total phosphorus (as $P$ ) of the Neuse River at Clayton and Kinston, 1974-77 water years. 
Nitrogen is frequently cited as the limiting nutrient in the Neuse River and estuary system (U.S. Army Corps of Engineers, 1973; Triangle J Council of Governments, 1976; Hobbie and Smith, 1975). That is to say that more nitrogen would be required before algae growth used up the available phosphorus. Therefore nitrogen reduction is the most likely goal for nutrient management. However, when nutrient-management control options are discussed, reductions in both nitrogen and phosphorus are usually recommended.

Variation in nutrient concentration is greatly influenced by discharge. Concentrations of dissolved nutrients plotted against discharge show dilution relations similar to that illustrated for dissolved solids and discharge (fig. 16). Furthermore, total nutrient concentrations respond during flow floods in a manner similar to sediment response. The total nitrogen and total phosphorus concentrations during the flood of August 4, 1974 (fig. 20) show a pattern of response comparable to that of sediment. The dissolved nitrogen and phosphorus concentrations are diluted by the flood flows, but nutrients associated with suspended material are greatly increased during the first peak in discharge. The net result is a flushing effect similar to that observed for Clayton suspended sediment data (fig. 9).

\section{BIOLOGICAL CHARACTERISTICS}

Biological monitoring is a direct means of assessing water-quality impacts in streams. Measurements of physical and chemical parameters give instantaneous levels of the materials in the waters of a stream. When reviewing these instantaneous values, special attention must be paid to complicating factors, such as discharge, that may make the values unrepresentative. In contrast, biological measures, such as algal assays, directly provide information on the short-term impacts of water quality in a stream. Finally, the variation found in the Neuse River in many of the physical or chemical parameters is too much to conclude a statistically significant change. Biological measures also exhibit substantial variation, but provide an alternate source of information about the study system to that provided by physical and chemical tests.

The systematic collection of biological data at Clayton and Kinston began in late 1973. Samples are collected at Clayton several times a year, and at Kinston monthly. Colony counts of fecal coliform bacteria and algal bioassays are performed for selected samples for both stations, and fecal streptococci bacteria colonies are counted for selected Kinston samples. The five-day biochemical oxygen demand $\left(\mathrm{BOD}_{5}\right)$ is determined for each sample from both stations.

\section{Bacteria}

Fecal coliform bacteria are those members of the coliform group found in the feces of various warm-blooded animals, and are used as indicators of bacteriological pollution. Fecal coliform statistics for both stations are given 


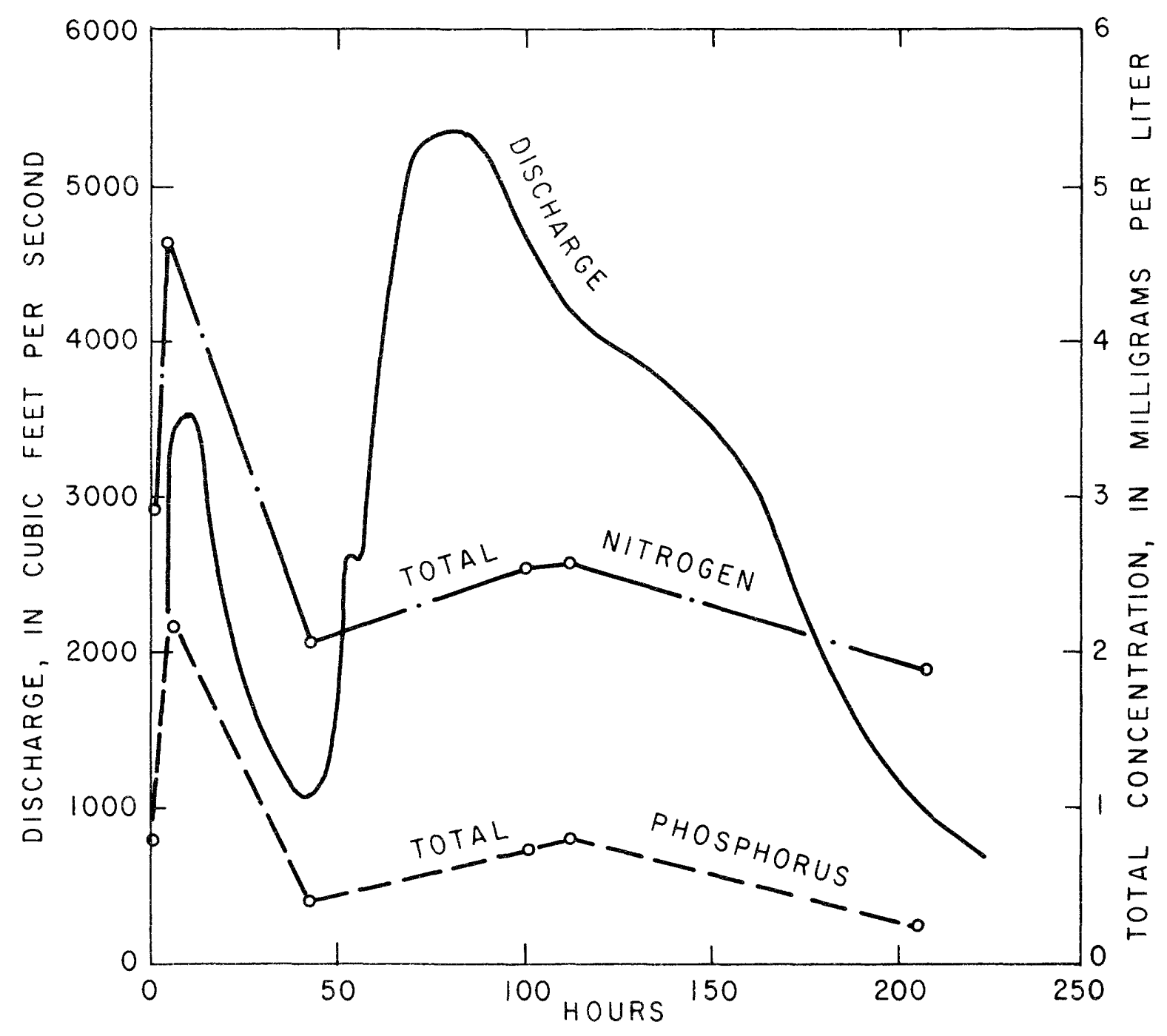

Figure 20.--Hydrograph of discharge, total nitrogen, and total phosphorus concentration for the storm of August 4, 1974, Neuse River at Clayton. 
in table 6. The fecal contamination levels at both stations exceed the recommended criterion for bathing waters (EPA, 1976). Kinston especially shows high fecal coliform levels.

Fecal streptococci also are organisms used to indicate fecal pollution from warm-blooded organisms. Although there are no criterion levels currently recommended for fecal streptococci, they supply a backup indicator to fecal coliform results. The fecal streptococci statistics (table 6) observed for Kinston samples corraborates the evidence of substantial bacterial contamination given by fecal coliform counts.

The fecal coliform-fecal streptococci ratio is sometimes used to help identify the origin of bacterial contamination (Geldreich, 1966). Ratios greater than 4.0:1 indicate contamination primarily of human origin, while ratios less than 0.6:1 indicate animal origin. Kinston fecal coliform to fecal streptococci ratios for low-flows (discharges less than $1,000 \mathrm{ft}^{3} / \mathrm{s}$ ) tend to fall between these values, indicating combined human-animal origin of the coliform bacteria.

\section{Biochemical oxygen demand}

The biological uptake of oxygen by organisms for metabolism can be measured by the five-day biochemical oxygen demand test $\left(B O D_{5}\right)$. Therefore, a stream's $\mathrm{BOD}_{5}$ helps to evaluate the amount of organic material in the stream being utilized by organisms. A range of 1 to $8 \mathrm{mg} / \mathrm{L}$ is common for moderately contaminated streams (Nemerow, 1974). BOD 5 values at both stations fall within this range. Fifty percent of the clayton values are less than $3 \mathrm{mg} / \mathrm{L}$, while 50 percent of the Kinston values are less than $2 \mathrm{mg} / \mathrm{L}$. Clayton has higher levels more frequently than Kinston.

\section{Algae}

Algae are simple plants that are ubiquitous in surface waters. In nutrient-enriched waters massive growths, or blooms, of algae may cause objectionable odors, impair water uses, and decrease aesthetic values of the body of water. Algae do not presently of ten cause such problems on the Neuse River. However, algal assays of samples collected at Clayton and Kinston provide a direct means of evaluation of effects of current nutrient concentrations. In addition, certain assemblages of dominant algal species serve as biological indicators of stream pollution in the Neuse.

Knowledge of algal growth levels are of particular interest in studies of lakes, estuaries and slowly moving rivers. Algae often play an important role in the oxygen balance of slowly moving water. High daytime dissolved-oxygen levels can largely be a funtion of photosynthetic activity. However, night-time respiration of the algae and decomposition of algal debris by microorganisms can deplete available oxygen and recycle nutrients into solution. 


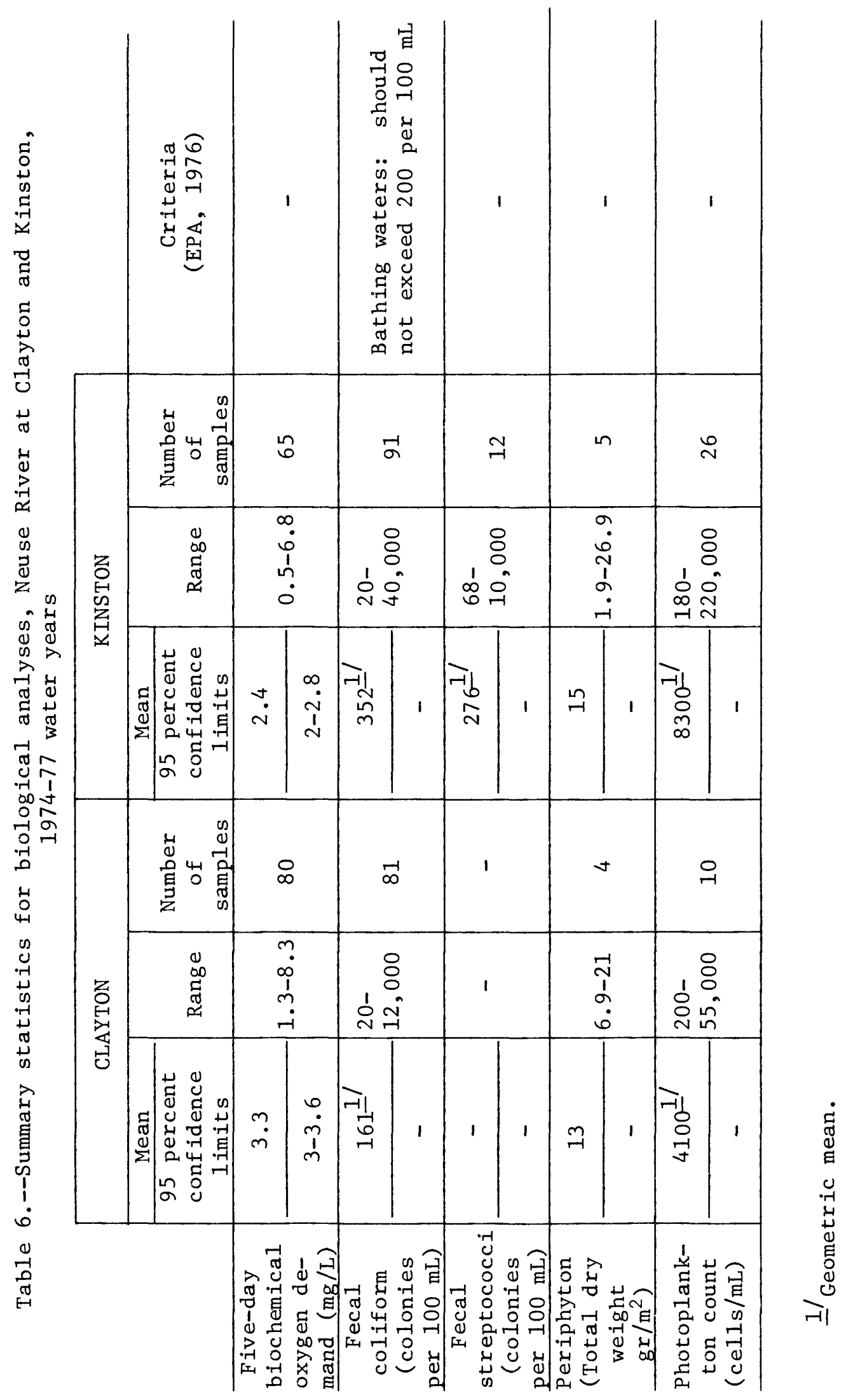


Rates of algal growth are highly dependent on temperature and the amount of sunlight, in addition to the availability of nutrients. Changes in growth of algae are as dramatic as the changes in the seasons. Not surprisingly, there is a distinct seasonal variation in algal cell counts at both Neuse stations. This variation is particularly apparent at Kinston (fig. 21). Algal cell counts are extremely high during summer months, reflecting the nutrient enrichment of the Neuse River (see Nutrients). Total cell counts at Kinston suggest that algae may play an important role in the oxygen balance of the lower reaches of the Neuse River.

Algal cell counts are also affected by streamflow. Flood flows often flush drifting organisms and phytoplankton downstream (Slack, 1974). This flushing may cause catastrophic changes in organism populations. One such turnover is documented at Kinston in figure 21. A precipitous drop in algal cell count, from 50,000 cells $/ 100 \mathrm{~mL}$ to 600 cells $/ 100 \mathrm{~mL}$, a five-fold decline in total algal cells in the river, corresponds to the flood of July 1975. Phytoplankton and nutrient loads flushed during high flows may seed algal blooms downstream and in the Neuse River estuary.

Annual distributions of the three predominant algal genera during 1974-76 at Clayton indicate a dominance of Chrysophyta (diatoma) much of the summer, fall and winter. The diatom genera that prevail include: Synedra, Nitzschia, Navicula and Melosira. Dominance of Chlorophyta (green algae) or Cyanophyta (blue-green algae) begins in February and lasts through midsummer. Blue-green algae genera that prevail during this period include Anacystis and Lyngbya. The dominant green algal genus that appears at Clayton in early summer is Scenedesmus. All of these genera, excluding Synedra, contain indicator species that are commonly associated with organically enriched waters (Nemerow, 1974).

Three complete water years of algal cell counts and identification are available at Kinston. The dominant assemblage of organisms has changed from year to year (table 7). The similar patterns of dominance apparent in 1975 and 1976, are different from that of 1977. In 1975 and 1976 diatoms and green algae were dominant. The summer months are characterized by an interplay of blue-green and green algal dominance. Diatom genera that prevail include: Navicula, Nitzschia, Melosira and Cyclotella. Blue-green algal genera that are dominant include: Oscillatoria, Anacystis and Lyngbya. Anacystis was the dominant algal genus from May 1975 to October 1975 and shared an important role with the diatom genera of Melosira and Cyclotelza in the same period the following year. Green algal genera dominant during 1975-1976 include: Ankistrodesmus, Crucigenia, Dictyosphaerium, Micractinium and Scenedesmus. Once again, most of these algal genera contain indicator species that are commonly associated with organically enriched waters (Nemerow, 1974).

In 1977 the pattern of dominance changes both at the division and generic level. Green algae predominate for much of the year. The genera that appeared including Dictyosphaerium, and Sphaerocystis, are not noted for indicator species of organic pollution. Significantly, this change in the pattern of generic dominance is first apparent in December 1976, when the Neuse River Wastewater Treatment Plant was activated (see Water Use and Waste Disposal). 


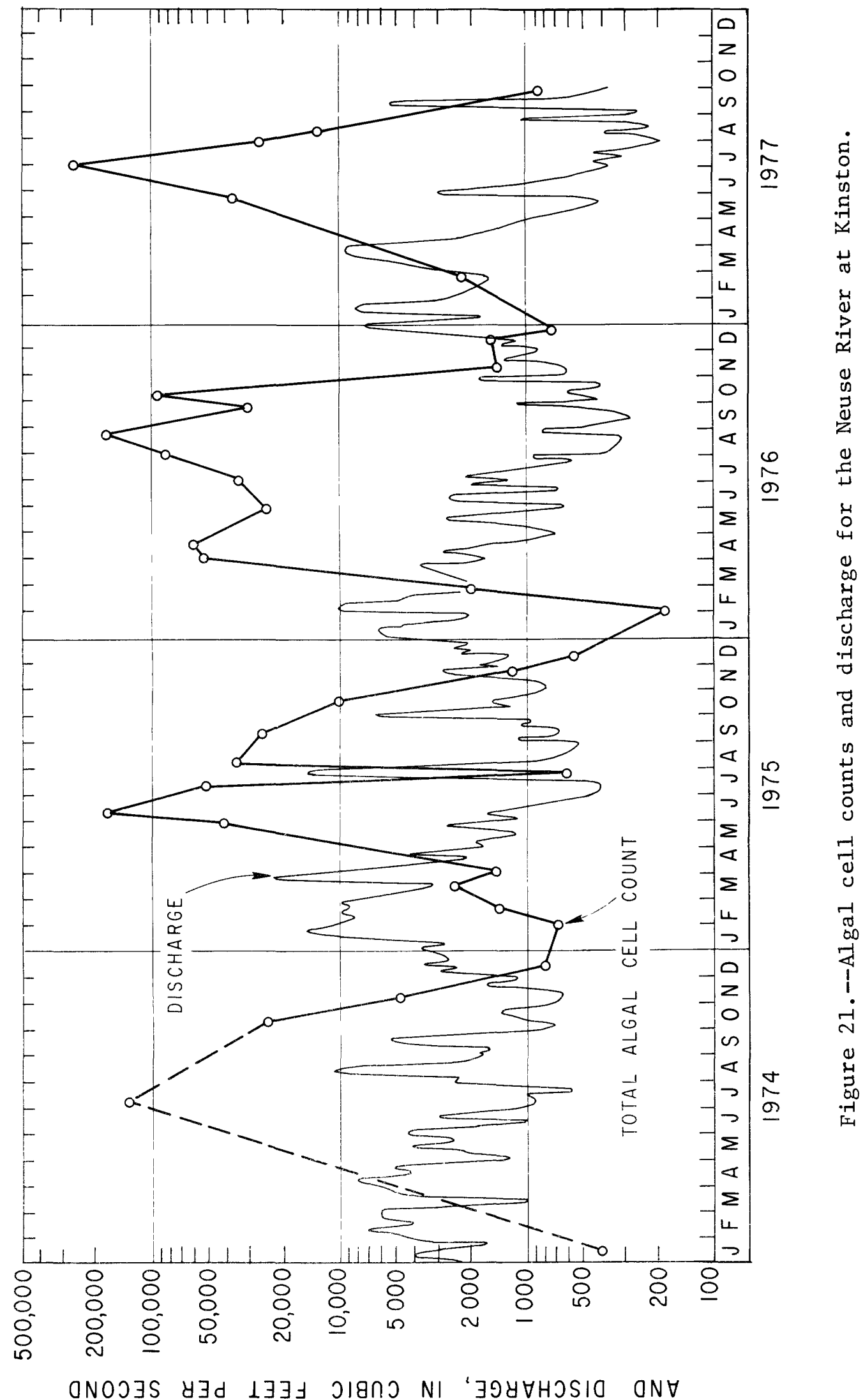

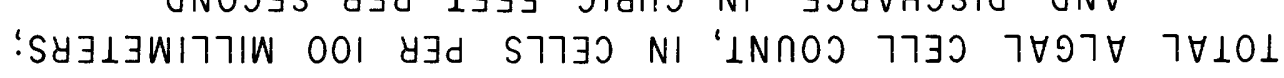


Table 7.--Major algal division dominance, represented by the percent of time over the water year in which each division is dominant, Neuse River at Kinston

\begin{tabular}{l|c|c|c}
\hline \multirow{2}{*}{ DIVISION } & \multicolumn{3}{|c}{$\begin{array}{c}\text { Percent of year } \\
\text { dominant }\end{array}$} \\
\cline { 2 - 4 } & 1975 & 1976 & 1977 \\
\hline $\begin{array}{l}\text { Cyanophyta } \\
\text { (blue-green algae) }\end{array}$ & 52 & 35 & 15 \\
\hline $\begin{array}{l}\text { Chlorophyta } \\
\text { (green-algae) }\end{array}$ & 43 & 42 & 69 \\
\hline $\begin{array}{l}\text { Chrysophyta } \\
\text { (diatoms) }\end{array}$ & 5 & 23 & 16 \\
\hline
\end{tabular}


Improved water treatment processes at this large plant may have reduced organic pollution in the Neuse enough to account for the altered pattern of algal dominance.

The recent history of Raleigh wastewater treatment suggests that the improvement of water quality due to the opening of the Neuse River treatment plant was preceded by degradation in water-quality (R. S. Taylor, North Carolina Department of Natural Resources and Community Development, written commun., June 20, 1979). In the year prior to the opening of the new plant, as sewer interceptor lines were under construction, the effluent discharge point for one of the old treatment plants was changed from a point several miles upstream in Walnut Creek, to a point near the confluence of Walnut Creek and the Neuse River. This change had the effect of removing any natural treatment of organic material in the effluent that would have occurred along Walnut Creek. Although there is evidence in Geological Survey data of improvement in water quality in the Neuse after the opening of the plant, in the form of reduced TOC concentrations, and changes in algal dominance, no change due to the re-location of the Walnut Creek plant effluent discharge point is apparent.

\section{POLLUTION}

A primary goal of this study is to identify how much of the total amount of dissolved and suspended material transported by the Neuse River is man-made pollution; that is, to find how man has changed the natural state of the stream. The accuracy of this evaluation hinges on the data available about the quality of water in the Neuse River prior to the influences of man. Very little, if any, natural water-quality data are available for the Neuse River, therefore it is necessary to make estimates of the natural state of the river based on data from other comparatively unpolluted streams.

\section{BASELINE WATER QUALITY}

Simmons and Heath (1979) describe the methods used by the Geological Survey to estimate the approximate natural, or baseline, water quality in North Carolina. A sampling program was designed to measure constituent concentrations during high and low flows in small unpolluted streams distributed across the State. Once the mean value of the constituent concentrations were known for both flow ranges at all of the baseline water-quality sites, the results were related to area geology. Thus, five distinct geochemical zones were identified, each containing a group of baseline water-quality stations with comparable constituent concentrations. Constituent concentrations from the sites within each group were averaged to give estimates of baseline waterquality concentrations for each geochemical zone.

Nine baseline water quality stations located within the Neuse Basin are shown in figure 1. The geochemical zones which include sections of the Neuse River basin are shown in figure 3. Parts of two geochemical zones lie within the Neuse basin upstream from Clayton. Area I covers $330 \mathrm{mi}^{2}$, and area II 
covers $810 \mathrm{mi}^{2}$ of this basin. Parts of four geochemical zones lie within the Neuse basin upstream from Kinston. Area I covers $590 \mathrm{mi}^{2}$, II covers $1180 \mathrm{mi}^{2}$, IV covers $730 \mathrm{mi}^{2}$, and $V$ covers $190 \mathrm{mi}^{2}$ of the basin.

Calculations of dissolved constituents derived from baseline sources and transported by large rivers, such as the Neuse, require three steps. First, the annual streamflow volume is broken down into high flow $Q_{H}$, and base flow, $Q_{B}$ (Rorabaugh, 1964). Second, the mean constituent concentrations ( $C_{H}$ for high flow and $C_{B}$ for base flow) determined from the baseline stations within each geochemical zone are weighted by the ratio of zone area to basin area, and then summed to give basin baseline-water-quality constituent concentrations.

Finally, these two basin water-quality concentrations are multiplied by the two components of total streamflow volume giving the annual baseline load $\left(\mathrm{L}_{\mathrm{N}}\right)$ :

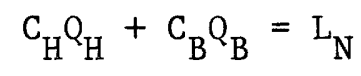

Separation (step 1) of Neuse River discharge into high flow and base flow components shows that for most years, the volume of high flow is greater than that of base flow. At Clayton, high flow averages 57 percent and base flow averages 43 percent of the total annual streamflow. At Kinston, high flow averages 66 percent and base flow averages 34 percent of the total annual flow. The large difference between the two stations in the relative proportions of high flow to base flow was an unexpected result. The significance of this difference warrants further investigation in future studies.

Comparisons of estimated natural water-quality concentrations (step 2) with water quality of samples from the Neuse are shown in table 8 for Clayton and table 9 for Kinston. Constituent concentrations for both the Neuse River and the baseline quality sites include precipitates of air-borne pollutants. The impact on water quality of atmospheric precipitation can be considerable (Gambel1 and Fisher, 1966) but data are not yet available to separate this source of pollution from other sources. An estimate of the portion of the mean sample concentration that is due to man's activity is given by subtracting the estimates of baseline water-quality from the corresponding constituent mean sample concentrations. Pollution usually makes up greater than 50 percent of the total constituent concentrations. Higher percentages of pollution at Clayton than at Kinston reinforce the observation that the water upstream is more heavily contaminated than downstream (see Water-Quality Variations).

There are a few cases in tables 8 and 9 where the estimates of baseline water quality are higher than the mean sample concentrations (silica, chromium, and mercury at Clayton; and silica, iron and mercury at Kinston). These cases are probably due to the small number of samples taken at the baseline waterquality sites. Spurious values, whether they represent actual stream concentrations or a combination of sampling and laboratory errors, bias the means calculated from a small number of samples.

Cation-anion diagrams provide a graphic means of comparison of the ionic composition of water at the baseline water-quality sites to the ionic composition of water from the Neuse (Stiff, 1951). The baseline water-quality 
Table 8.--Comparison of water quality of samples from the Neuse River at clayton with samples from baseline water-quality sites in the basin upstream from Clayton

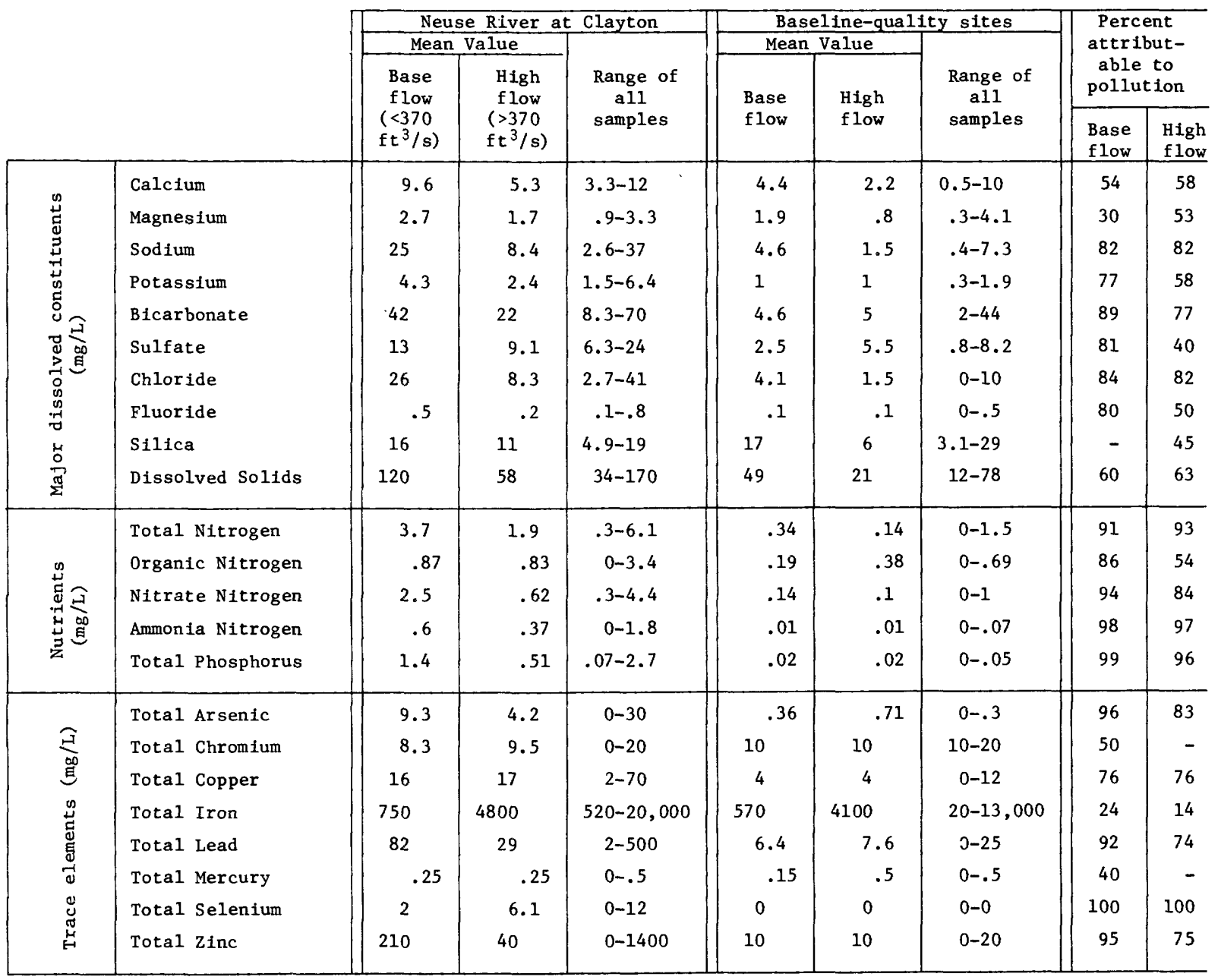


Table 9.--Comparison of water quality of samples from the Neuse River at Kinston with samples from baseline water-quality sites in the basin upstream from Kinston

\begin{tabular}{|c|c|c|c|c|c|c|c|c|c|}
\hline & & \multicolumn{3}{|c|}{ Neuse River at Kinston } & \multicolumn{3}{|c|}{ Baseline-quality sites } & \multirow{3}{*}{\multicolumn{2}{|c|}{$\begin{array}{l}\text { Percent } \\
\text { attribut- } \\
\text { able to } \\
\text { pollution }\end{array}$}} \\
\hline & & Mear & Value & \multirow{3}{*}{$\begin{array}{l}\text { Range of } \\
\text { all } \\
\text { samples }\end{array}$} & \multicolumn{2}{|c|}{ Mean Value } & \multirow{3}{*}{$\begin{array}{l}\text { Range of } \\
\text { alI } \\
\text { samples }\end{array}$} & & \\
\hline & & \multirow{2}{*}{$\begin{array}{l}\text { Base } \\
\text { flow } \\
(<370 \\
\left.\mathrm{ft}^{3} / \mathrm{s}\right)\end{array}$} & \multirow{2}{*}{$\begin{array}{l}\text { High } \\
\text { flow } \\
(>370 \\
\left.\mathrm{ft}^{3} / \mathrm{s}\right)\end{array}$} & & \multirow{2}{*}{$\begin{array}{l}\text { Base } \\
\text { flow }\end{array}$} & \multirow{2}{*}{$\begin{array}{l}\text { High } \\
\text { flow }\end{array}$} & & & \\
\hline & & & & & & & & $\begin{array}{l}\text { Base } \\
\text { flow }\end{array}$ & $\begin{array}{l}\text { High } \\
\text { flow }\end{array}$ \\
\hline & Calcium & 6.9 & 4.8 & $3.2-8.8$ & 2.9 & 1.9 & $0.2-4.0$ & 58 & 60 \\
\hline 岂 & Magnes fum & 2 & 1.5 & $1.1-2.5$ & 1.3 & .6 & $.1-4.1$ & 35 & 60 \\
\hline & Sodium & 12 & 6.3 & $3 \cdot 5-17$ & 3.8 & 1.8 & $.4-7.3$ & 67 & 71 \\
\hline & Potassium & 3.1 & 2.3 & $1.7-4$ & .8 & .8 & $.1-1.9$ & 70 & 65 \\
\hline نิ & Bicarbonate & 29 & 15 & $7-40$ & 3.4 & 3.3 & $0-44$ & 88 & 78 \\
\hline 800 & Sulfate & 11 & 9.5 & $7 \cdot 2-15$ & 4.3 & 6.3 & $.6-13$ & 61 & 34 \\
\hline 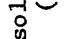 & Chloride & 11 & 7.2 & $3.6-17$ & 3.9 & 2.3 & $0-10$ & 66 & 68 \\
\hline$\underset{7}{n}$ & Fluoride & .2 & .2 & $0-.5$ & .1 & .1 & $0-.5$ & 50 & 50 \\
\hline Ho & Silica & 9.4 & 9.2 & $3.1-14$ & 13 & 5.4 & $1.4-29$ & - & 41 \\
\hline$\frac{\pi}{2}$ & Dissolved Solids & 70 & 49 & $34-91$ & 39 & 22 & $11-78$ & 44 & 55 \\
\hline & Total Nitrogen & 1.4 & 1.2 & $.6-2.1$ & .4 & .5 & $0-1.5$ & 71 & 58 \\
\hline & Organic Nitrogen & .7 & .7 & $.06-1.1$ & .3 & .4 & $0-.99$ & 57 & 43 \\
\hline 氙 & Nitrate Nitrogen & - & - & -- & .09 & .08 & $0-1$ & - & - \\
\hline$\stackrel{+\infty}{ \pm 0}$ & Ammonia Nitrogen & .03 & .09 & $.02-.27$ & .01 & .01 & $0-.07$ & 67 & 89 \\
\hline & Total Phosphorus & .3 & .2 & $.07-.38$ & .02 & .02 & $0-.05$ & 93 & 90 \\
\hline & Total Arsenic & 4.4 & 5.3 & $0-50$ & .3 & .6 & $0-6$ & 93 & 89 \\
\hline 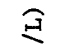 & Total Chromium & 13 & 12 & $10-20$ & 10 & 10 & $0-20$ & 50 & 33 \\
\hline$\stackrel{\infty}{3}$ & Total Copper & 9.6 & 9.1 & $2-40$ & 3.4 & 3.3 & $0-12$ & 65 & 64 \\
\hline is & Total Iron & 1100 & 1400 & $650-2000$ & 540 & 2800 & $60-29,000$ & 50 & - \\
\hline 离 & Total Lead & 30 & 18 & $0-100$ & 5.7 & 6.7 & $0-29$ & 81 & 64 \\
\hline$\frac{a}{d}$ & Total Mercury & .28 & .12 & $0-2.2$ & .3 & .5 & $0-.5$ & - & - \\
\hline 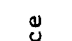 & Total Selenium & .50 & .73 & $0-5$ & 0 & 0 & $0-0$ & 100 & 100 \\
\hline$\underset{\mathrm{m}}{\mathrm{m}}$ & Total $\mathrm{Z}$ inc & 17 & 42 & $4-14$ & 10 & 10 & $0-30$ & 42 & 76 \\
\hline
\end{tabular}


diagram is superimposed on the observed water-quality diagram for the Neuse at Clayton and Kinston in figure 22. There is little apparent difference in the baseline water-quality between the two stations. However, pollution, which is represented in the diagrams by the difference between the measured and baseline water quality, is greater at Clayton than at Kinston.

The third step in calculating baseline material transport $\left(L_{N}\right)$ in the Neuse River is the insertion of the baseline water-quality concentrations $\left(C_{H}, C_{B}\right)$ summarized in tables 8-9, and the high flow and base flow $\left(Q_{H}, Q_{B}\right)$ into equation 2. The results of this calculation for dissolved solids are given as an example in tables 10 and 11 (columns $C, D$, and $E$ ) and figures 23 and 24 (items B, C, D) for Clayton and Kinston, respectively.

It is interesting to note that at Clayton the estimated baseline load in high flow is consistently lower than the natural load in base flow while at Kinston the estimated baseline load in high flow is frequently greater than the load in base flow (see figs. 23 and 24). This is because of the relatively large base-flow baseline dissolved-solids concentrations estimated for Clayton and the greater proportion of high flow to base flow at Kinston.

\section{POLLUTION LOADS}

Two additional steps are required to estimate the annual pollution load once the annual baseline load has been evalutated. First, the total annual load must be determined. Although daily streamflow and specific conductance values are usually available, concentration values for water quality parameters are determined from samples collected on a monthly or bi-monthly basis. The concentration values are regressed on specific conductance, producing linear relations (see Water-Quality Variations) that are in turn used to estimate daily concentrations from daily conductance data. Examples of these relations are shown in figures 14 and 15. Daily concentrations are multiplied by daily streamflows to produce daily loads. The sum of these daily loads for a year's time yields the total annual load. The results of these calculations for Clayton are given in table 10 and figure 23, and for Kinston in table 11 and figure 24.

It is important to note that although daily specific conductances were not measured at either station during 1964-67, specific conductance was evaluated each time a water-quality sample was taken. These periodic values were then regressed on daily specific conductance values measured at an upstream station. The upstream station used for Clayton was Neuse River at Fal1s (02087183), and the station used for Kinston was Neuse River at Goldsboro (02088821). Equations produced in these regressions were then used to generate estimates of daily values for the Clayton and Kinston stations. The estimated specific conductances have been used in evaluation of total loads for the 1964-67 wateryears for both stations.

The pollution load is derived by taking the difference between the total load and the baseline load. The results of the calculation for dissolvedsolids pollution loads for Clayton are shown in table 10 and for Kinston in table 11 . 

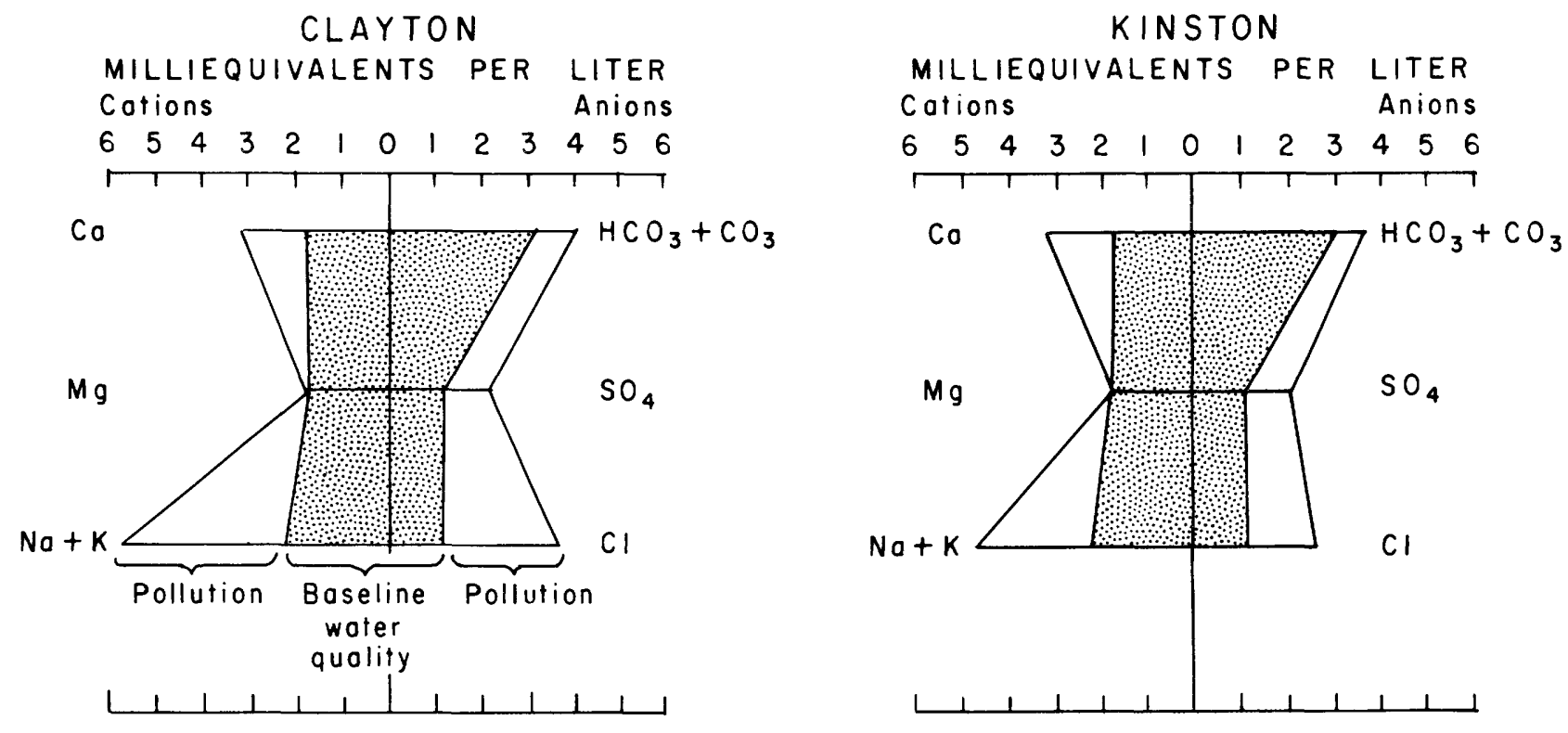

Figure 22.--Comparisons of baseline water quality and observed water quality using cation-anion diagrams. The observed-data diagrams represent the mean of all samples taken in the 1974-77 water years. The baseline water-quality diagram represents the mean of all samples taken from baseline stations within the Neuse River basin. 


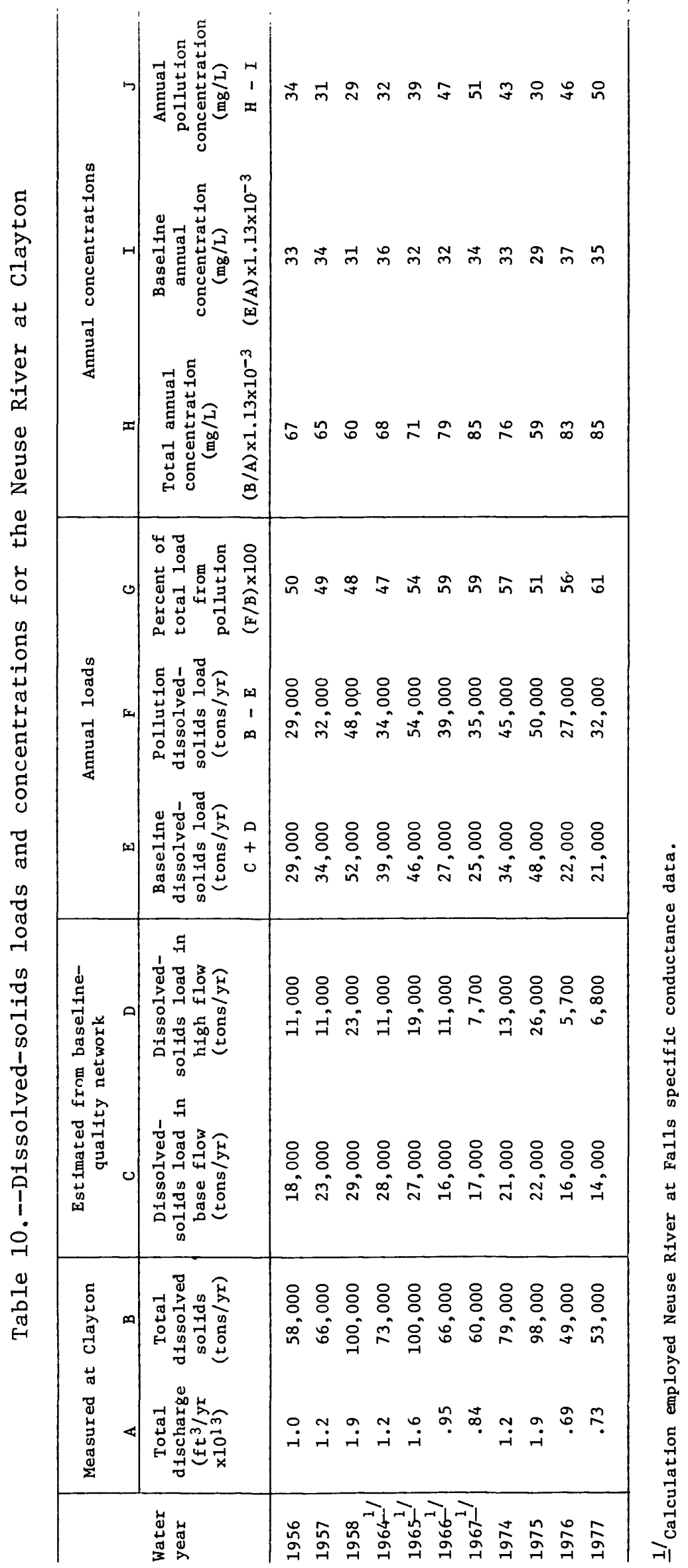




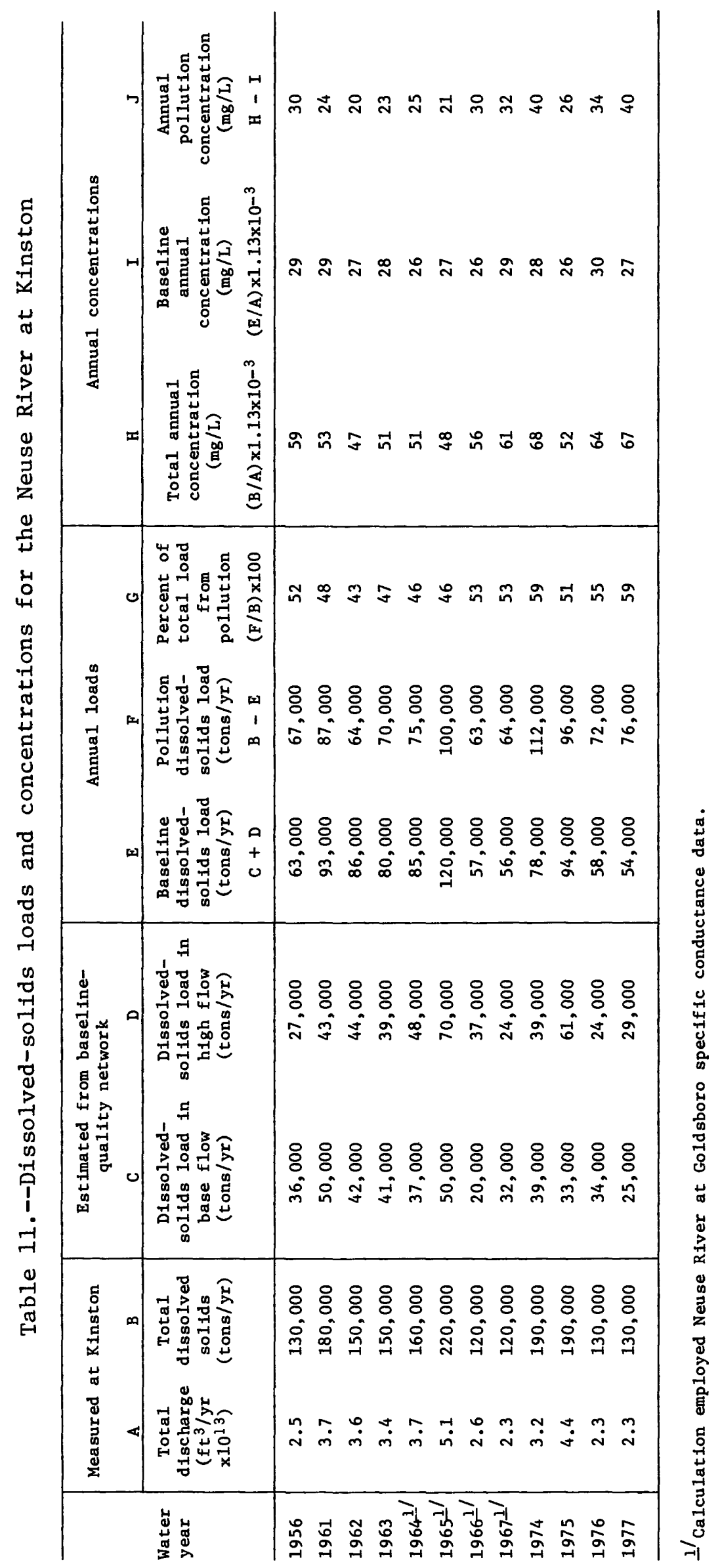




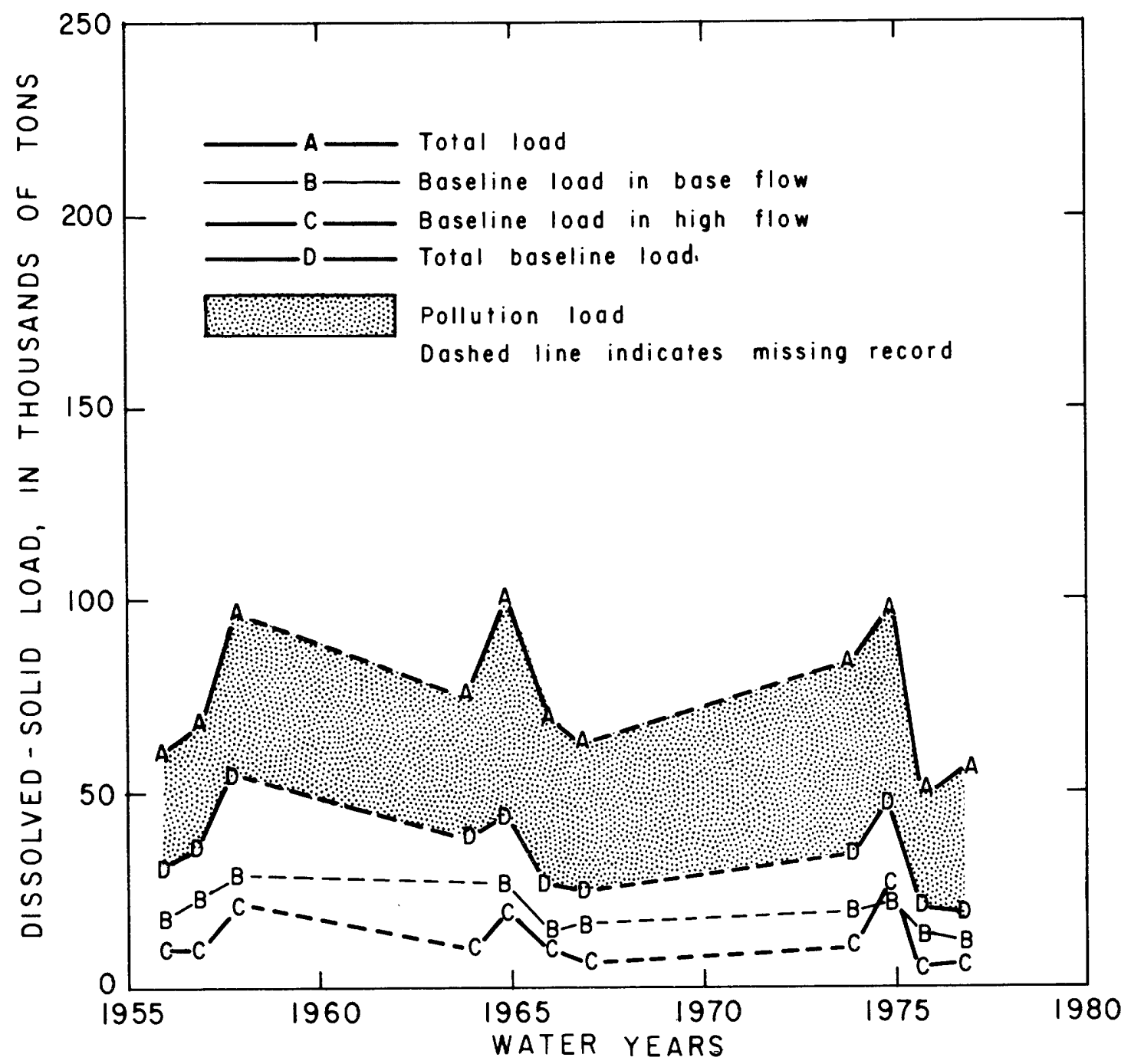

Figure 23.--Dissolved-solids load for the Neuse River at Clayton. 


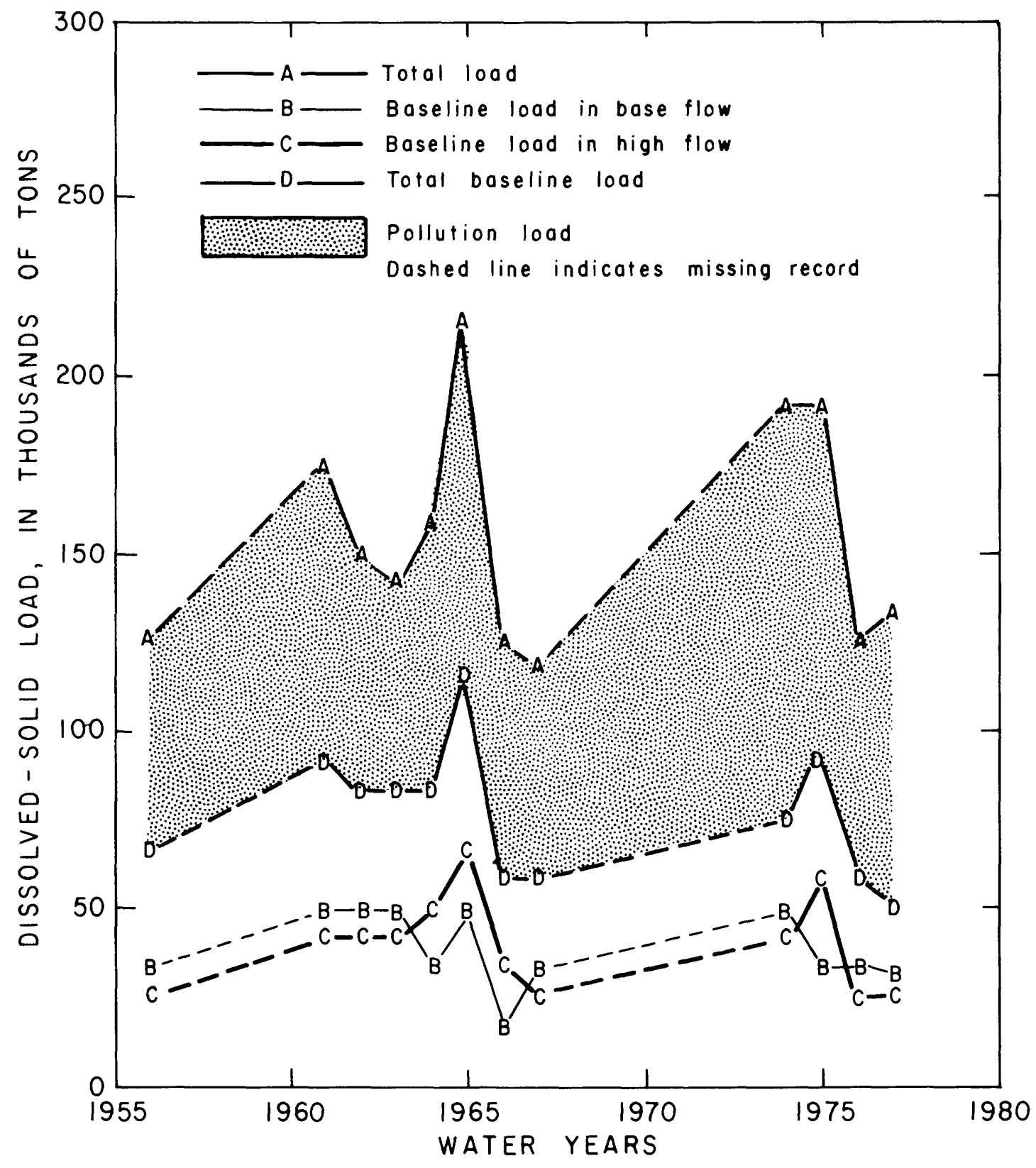

Figure 24.--Dissolved-solids load for the Neuse River at Kinston. 
The depictions of dissolved-solids loads in figures 23 and 24 vividly demonstrate the importance of pollution in the make-up of the overall water quality of the Neuse. The plot of total baseline load gives a representation of what the dissolved solids loads of the Neuse River would be without the presence of man. However, these load estimates are probably high because they include the effects of air-borne pollutants. The areas in figures 23 and 24 between the total baseline load and the total load represent the dissolved solids pollution loads.

The proportion of the total load that is pollution is similar at both stations (figs. 23 and 24). This similarity between Clayton and Kinston is more apparent when that part of the total load attributable to pollution is calculated as a percentage, as shown in figure 25. The dissolved-solids load due to pollution averages 53 percent for the period of record at clayton and 51 percent at Kinston. On an annual basis the widest difference between stations occurs during the $1960^{\prime} \mathrm{s}$, when Clayton shows appreciably higher percentages compared to Kinston. This difference is probably due to the process of specific conductance estimation using upstream values to evaluate the total loads.

When the difference between the dissolved solids pollution loads at Kinston and Clayton is divided by the difference between the total loads at these two stations, the proportion that results is a measure of the contribution of pollution from the basin area lying between the two stations. These Kinstonminus-Clayton results ( $\mathrm{fig} .25$ ) indicate that little pollution is contributed to the Neuse between these two sites.

During the high discharge years of 1965 and 1975 the percentages of total dissolved-solids load from pollution show large decreases (see fig. 25). During these two years the baseline loads are high, so that on a percentage basis of the total load, load due to pollution is less. However, the baseline high-flow loads are calculated assuming the same geochemical zone concentrations for wet and dry years. If, in fact these concentrations vary significantly from the average value during extreme discharge years, then the baseline-load estimates are inaccurate. For example: if during years of high discharge the high-flow baseline concentration decreases due to dilution, then the baseline load would be lower than that calculated from an average value.

Comparisons between dissolved-solids loads at the two stations on the basis of load per square mile of drainage area are given in table 12 for total loads, baseline loads and pollution loads. Clayton stands out in the total load comparison as having the greatest loads per square mile in all but the most recent years. Clayton and Kinston show much higher per-square-mile pollution loads in all but the most recent years. The area between the two stations shows loads similar to Kinston.

These results suggest an improvement in water-quality at clayton and Kinston in recent years. The year where improvement was first evident, 1976, matches the time when algal dominance changes were first observed at Kinston (see Biological Characteristics). Both changes correspond to the opening of the Neuse River Wastewater Treatment Plant - possibly the most significant event for water quality of the Neuse River during the period of study. 


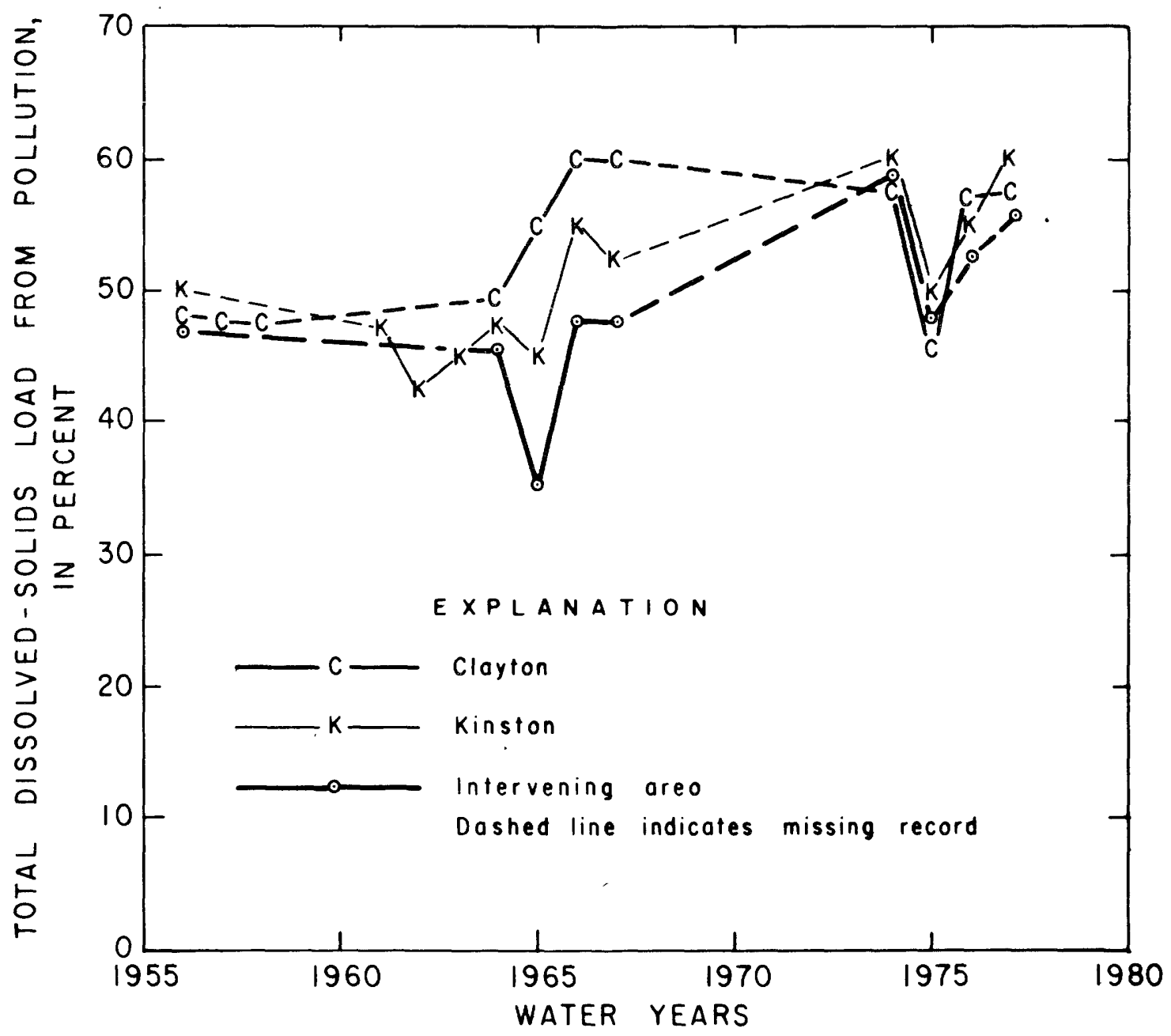

Figure 25.--Percentage of total dissolved-solids load from pollution for the Neuse River at Clayton and Kinston, and the invervening area between stations. 


\begin{tabular}{|c|c|c|c|c|c|c|c|c|c|c|c|c|c|c|c|c|}
\hline $\begin{array}{l}0 \\
0 \\
\pi \\
0 \\
-1\end{array}$ & \multirow{3}{*}{ 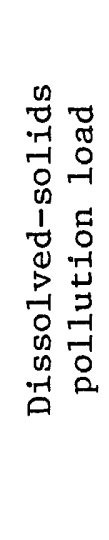 } & 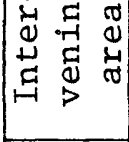 & $\stackrel{\mathscr{n}}{N}$ & 1 & 1 & 1 & 1 & 1 & $\stackrel{\sigma}{N}$ & ㅇ & $\stackrel{\text { จ }}{ }$ & $\stackrel{9}{\rightarrow}$ & $\stackrel{m}{\sim}$ & ㅇ & $\stackrel{\curvearrowright}{\sim}$ & $\stackrel{\infty}{\sim}$ \\
\hline $\begin{array}{l}0 \\
-1 \\
-1 \\
0 \\
1 \\
1 \\
0 \\
0\end{array}$ & & 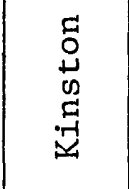 & $\stackrel{n}{\sim}$ & 1 & 1 & $\tilde{m}$ & $\stackrel{ \pm}{\sim}$ & $\stackrel{\bullet}{\sim}$ & $\stackrel{\infty}{\sim}$ & $\hat{m}$ & $\stackrel{m}{\sim}$ & $\stackrel{ \pm}{\sim}$ & $\stackrel{\mathcal{V}}{\mathcal{V}}$ & m & $\grave{\sim}$ & $\stackrel{\infty}{\sim}$ \\
\hline 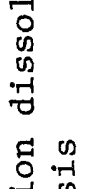 & & 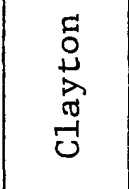 & $\stackrel{n}{N}$ & $\stackrel{\infty}{\sim}$ & $\stackrel{\sim}{\sim}$ & 1 & 1 & 1 & $\stackrel{\mathrm{m}}{ }$ & $\mathcal{y}$ & ले & $\vec{m}$ & $\stackrel{0}{+}$ & $\stackrel{\Xi}{*}$ & $\stackrel{ \pm}{\sim}$ & $\stackrel{\infty}{\sim}$ \\
\hline 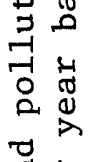 & \multirow{3}{*}{ 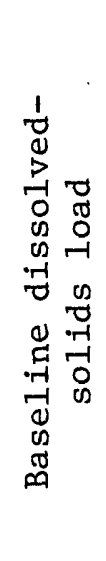 } & 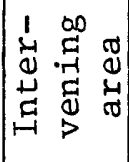 & $\mathbb{N}$ & 1 & 1 & 1 & 1 & 1 & 음 & $\stackrel{\infty}{\underset{J}{+}}$ & ન్తి & $\stackrel{\text { ㄱ }}{ }$ & $\stackrel{\infty}{\sim}$ & 이 & $\stackrel{m}{\sim}$ & $\stackrel{-1}{\sim}$ \\
\hline 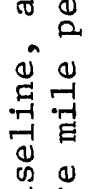 & & 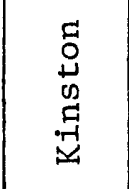 & $\stackrel{n}{N}$ & 1 & 1 & $\tilde{m}$ & N & @ి & $\tilde{m}$ & $\stackrel{\ddagger}{\ddagger}$ & $\vec{\sim}$ & $\stackrel{-}{\sim}$ & ㅇ & $\stackrel{n}{m}$ & $\widetilde{N}$ & $\stackrel{ }{N}$ \\
\hline 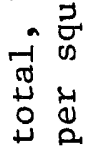 & & 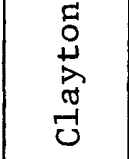 & $\stackrel{\curvearrowleft}{\sim}$ & 을 & $\stackrel{0}{+}$ & 1 & 1 & 1 & mे & $\stackrel{0}{9}$ & $\stackrel{\text { N }}{*}$ & N & 을 & $\underset{乛}{\mathcal{F}}$ & $\stackrel{\sigma}{\sigma}$ & $\stackrel{\infty}{\sim}$ \\
\hline 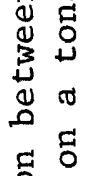 & \multirow{3}{*}{ 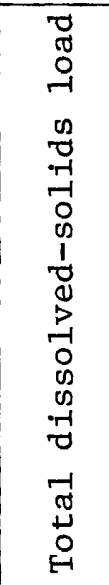 } & 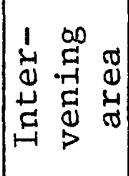 & $\stackrel{0}{+}$ & 1 & 1 & 1 & 1 & 1 & เก & $\hat{n}$ & $\stackrel{\sigma}{\sigma}$ & & $\stackrel{N}{N}$ & ก) & กี & 은 \\
\hline 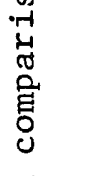 & & 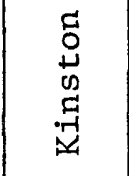 & $\stackrel{\infty}{\mathcal{N}}$ & 1 & 1 & $\hat{\sigma}$ & in & 许 & ชి & $\underset{\infty}{\infty}$ & $\stackrel{n}{\sim}$ & $\stackrel{\Perp n}{\sigma}$ & $\pi$ & $\stackrel{-1}{\pi}$ & $\stackrel{\infty}{\rightarrow}$ & $\stackrel{\infty}{\underset{\sim}{*}}$ \\
\hline$\underset{-1}{\sim}$ & & $\underset{\substack{0 \\
0}}{\stackrel{0}{0}}$ & 댁 & $\stackrel{\infty}{\infty}$ & $\underset{\infty}{\infty}$ & 1 & 1 & 1 & పే & $\begin{array}{l}\infty \\
\infty\end{array}$ & $\stackrel{\infty}{n}$ & in & శิ & $\infty$ & $\stackrel{m}{q}$ & $\Im$ \\
\hline & \multicolumn{2}{|c|}{ 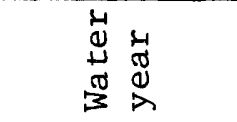 } & $\begin{array}{l}\text { ڤn } \\
\text { â }\end{array}$ & in & $\stackrel{\text { }}{\sim}$ & નु- & ๙ু & $\begin{array}{l}\hat{\sigma} \\
\text { ने }\end{array}$ & \begin{tabular}{l}
\multirow{J}{}{} \\
ने
\end{tabular} & $\begin{array}{l}n \\
\text { ڤू } \\
\text { - }\end{array}$ & $\begin{array}{l}\text { ठ̊ } \\
\text { مे }\end{array}$ & $\begin{array}{l}\hat{\sigma} \\
\sigma \\
-1\end{array}$ & $\underset{\sim}{\stackrel{N}{\sigma}}$ & $\stackrel{n}{\frac{n}{n}}$ & $\stackrel{0}{\frac{0}{9}}$ & $\stackrel{\hat{\sigma}}{\hat{\sigma}}$ \\
\hline
\end{tabular}


The results shown in table 12 are particularly interesting in light of the information presented in figures 3 and 4 . The density of population in the drainage area above Clayton is the highest in the entire Neuse basin, with roughly 40 percent of the population (fig. 3) and only 20 percent of the drainage area. In contrast, the area between Clayton and Kinston has a much lower population density with about 25 percent of the total basin population and 27 percent of the drainage area. Clearly, there should be a strong correlation between the degree of pollution of a river and the degree of the presence of the polluter - man. This point is echoed by the information presented in figure 4 on industrial point-source discharges. Land-use, industry and pollution are all functions of population, albeit complex and variable functions. Correlations between population and pollution in the Neuse River basin will be explored further in the next section of this report.

Although dissolved-solids loads give rough measures of water-quality, examination of individual dissolved material is necessary to identify the nature of water-quality changes with time. Summary breakdowns of the total loads of sodium, sulfate, and chloride, into baseline and pollution loads for both stations are given in table 13. Although the percent of the average load attributable to dissolved solids pollution was earlier shown to be similar for Clayton and Kinston (fig. 25), there is a wide variation between average values for other constituents. In all three constituents listed in table 13, Kinston shows much lower percentage of a load attributable to pollution than Clayton. The variation in degree of pollution among constituents cannot be explained adequately without a detailed pollution sources study. However, the following section will attempt to quantify the trends that can be observed in this pollution data.

\section{TRENDS}

\section{TREND ANALYSIS TECHNIQUES}

The final goal of this study is to quantify how water quality in the Neuse River has changed historically. Determination of trends is not a simple problem. Ideally, the data used in trend analysis should be derived from standardized measurements of samples collected randomly or according to welldefined experimental design, over a continuous and long-term period. However, the Neuse River data available for trend analysis does not fit this ideal format. Sample collection in the past, as well as the present, is conducted on a temporal basis influenced by sampling costs, available personnel, weather conditions, field-trip schedules and a host of other variables. The resultant sampling intervals are not random, set to any experimental design, or long term. The data are also discontinuous, with several periods of missing waterquality records lasting four or more years.

In spite of these inconsistencies, the water-quality data is valuable because it is neither replaceable nor reproducable. The data collected by the U.S. Geological Survey represents the longest water-quality record available for the Neuse River, dating back at least twenty years. In order to use these data to evaluate water-quality trends, several different methods of data modeling and data transformation have been applied. All of the methods for 
Table 13.--Average loads of sodium, chloride, and sulfate transported by the Neuse River at Clayton and Kinston, 1974-77 water years

\begin{tabular}{|c|c|c|c|c|c|}
\hline & Constituent & $\begin{array}{l}\text { Total load } \\
\text { (tons/yr) }\end{array}$ & $\begin{array}{c}\text { Baseline } \\
\text { load } \\
\text { (tons/yr) }\end{array}$ & $\begin{array}{c}\text { Pollution } \\
\text { load } \\
\text { (tons/yr) }\end{array}$ & $\begin{array}{l}\text { Percent } \\
\text { attribut- } \\
\text { able to } \\
\text { pollution }\end{array}$ \\
\hline \multirow{3}{*}{ 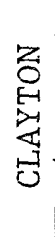 } & Sodium & 8,300 & 2,200 & 6,100 & 73 \\
\hline & Chloride & 8,200 & 2,500 & 5,700 & 70 \\
\hline & Sulfate & 8,600 & 4,200 & 4,400 & 51 \\
\hline \multirow{3}{*}{ 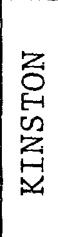 } & Sodium & 16,000 & 6,000 & 10,000 & 63 \\
\hline & Chloride & 18,000 & 7,000 & 11,000 & 61 \\
\hline & Sulfate & 22,000 & 15,000 & 7,000 & 32 \\
\hline
\end{tabular}


trend analysis that have been used were developed for this study. Since all data-smoothing trend analysis techniques are subject to error, the methods used and their results are described in detail. To facilitate discussion, the data manipulations will be catagorized into three methods of evaluating trends:

(1) Pollution load estimation

(2) Discharge normalization, and

(3) Discharge-frequency weighting

These three methods of trend analysis share a few basic assumptions. First, the laboratory data are assumed to be comparable from year to year. Several constituents that show suspicious changes in concentration levels from one year to the next have been dropped from consideration in trend analysis. We have also assumed that grouping the data by water year, and data transformation procedures employed in the trend analysis methods will counter sampling bias.

\section{Pollution-load estimation technique}

The pollution-load estimation technique has been briefly outlined in the Pollution section of this report and is described fully by Wilder and Simmons (1978), and Simmons and Heath (1979). The annual pollution loads estimated by this technique (tables 10 and 11) are plotted against time, and the regression line through the points provides a gross measure of trend over the period of record. An example of this type of plot is presented in figure 26 which shows increasing trends in potassium pollution loads at both stations. The regression lines indicated in figure 26 both have slopes that are significantly different from zero slope (two-tailed t-test, 0.05 probability level).

Although the confidence envelope indicates with some certainty that there has been an increase in potassium loads over the past 20 years, there is still a great deal of year to year variation in the data. The pollution load is the product of pollution concentration and discharge, therefore, annual pollution loads vary directly with annual discharges. The pollution load estimation process (see POLLUTION) employs several procedures that are important to consider in trend analysis. Hydrograph separation adds error to pollution-load estimates already highly influenced by year-to-year variances in discharge. The combination of hydrograph-separation error with the annual variation due to discharge explains much of the scatter seen in the plot of figure 26. Clearly, extraction of the effect that discharge has on constituent loads is highly desirable, particularly to detect trends in constituents that may not be of sufficient magnitude to overshadow the effects of discharge. The dischargenormalization and discharge-frequency-weighting methods, to be described presently, are both techniques designed to reduce or eliminate the variation in constituent concentration due to discharge. 


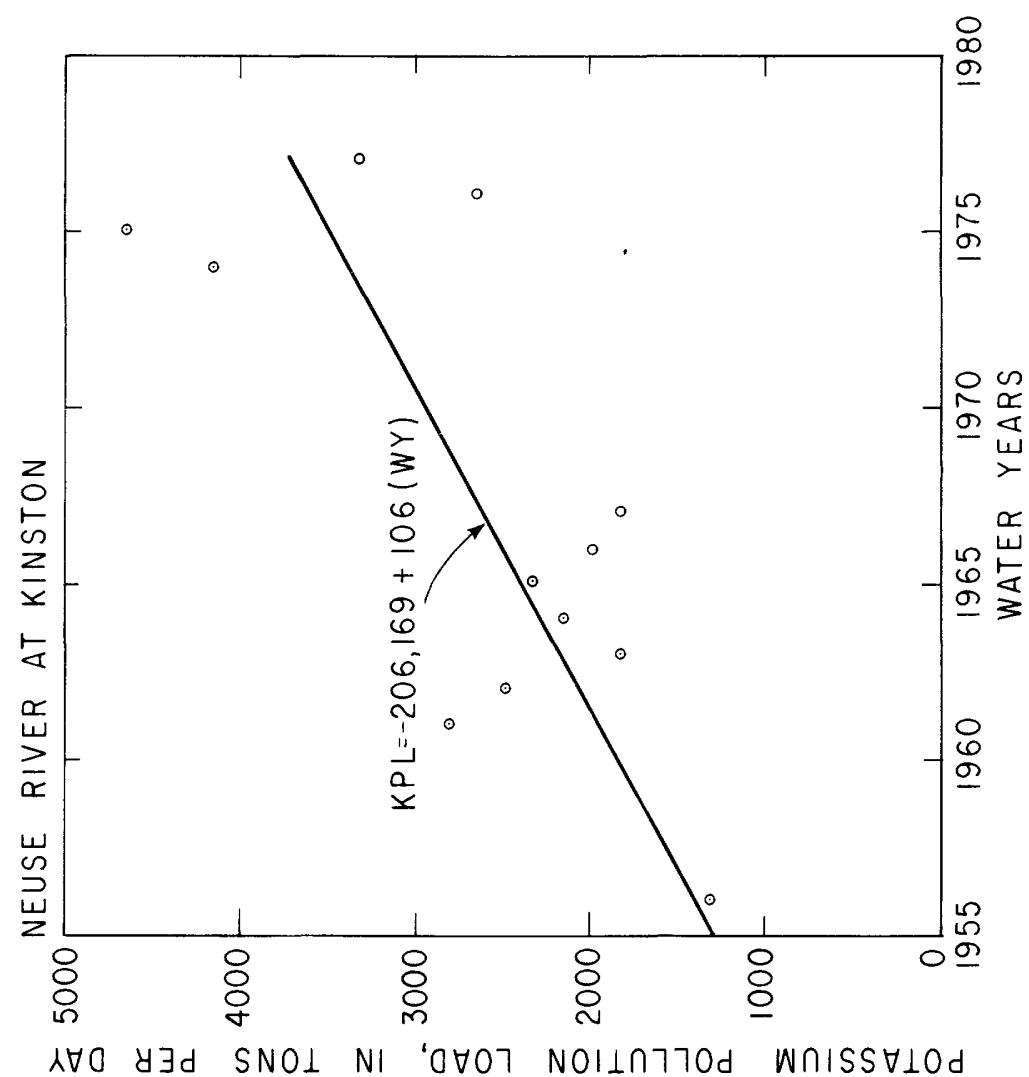

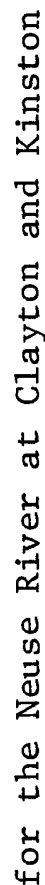

㐘

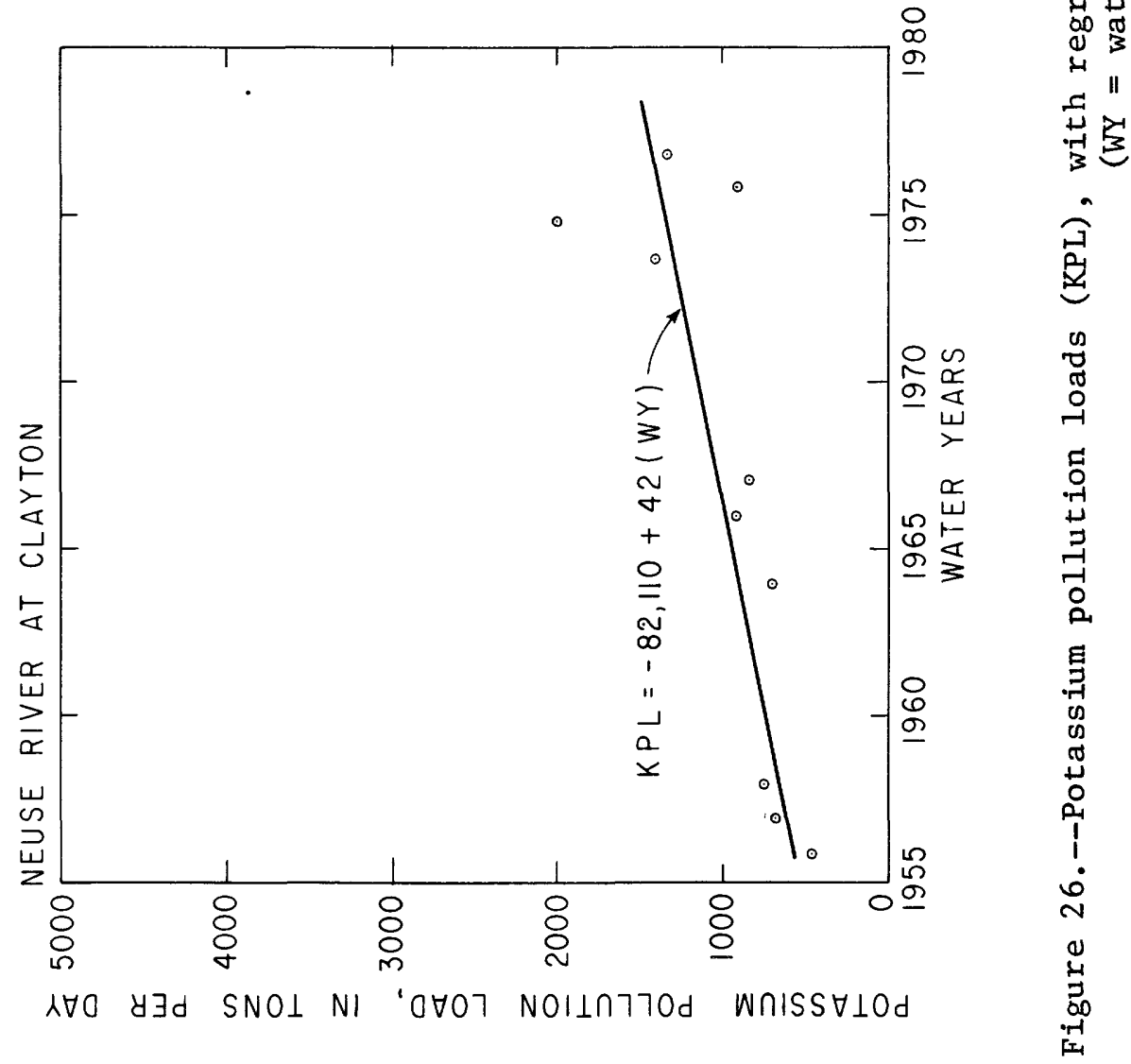


The dependency of the pollution-load estimation technique on the accuracy of regression relations adds a complicating factor to trend analysis. Some yearly variation due to inaccuracy of the constituent - specific conductance relationships is expected, and can be demonstrated by a comparison of observed and computed constituent concentrations. This inaccuracy is generally \pm 5 to 10 percent. However, this variance is year-by-year, and does not necessarily cause a bias in the overall 20-year trends. Therefore, the pollution-load estimation technique has been applied only in the evaluation of long-term trends.

\section{Discharge-normalization technique}

The second approach of transformation of the water-quality data, discharge normalization, was developed by Charles Daniel (U.S. Geological Survey, written commun., December 1978). This method can be broken down into three steps:

(1) Shift daily discharges on an annual basis to a central period-of-record discharge value,

(2) Adjust daily specific conductance to compensate for the shift in discharges, and

(3) Estimate daily constituent concentrations using the adjusted specific conductance values and constituent concentration versus specific conductance relations.

The estimated concentrations are averaged to produce normalized annual concentrations, or normalized annual loads are derived from the concentrations and the normalized discharges. The term "normalization" as used here refers to the process of adjusting discharge to one standard frequency distribution. This approach is designed to adjust, or normalize, annual discharge frequency distributions so that they approximate the form of the period-of-record discharge frequency distribution. A flow chart of the discharge-normalization technique is presented in figure 27.

The first step initially requires the calculation of a central discharge value for the period of discharge record. The central value used in this analysis was the average of the mean $(\bar{x})$ and median $(m)$ discharges for the period of record ( $R$, steps $1-3$ in fig. 27):

$$
\frac{\bar{x}_{R}+m_{R}}{2}=V_{R}
$$

where $V_{R}$ is the central discharge value for the period of record. 


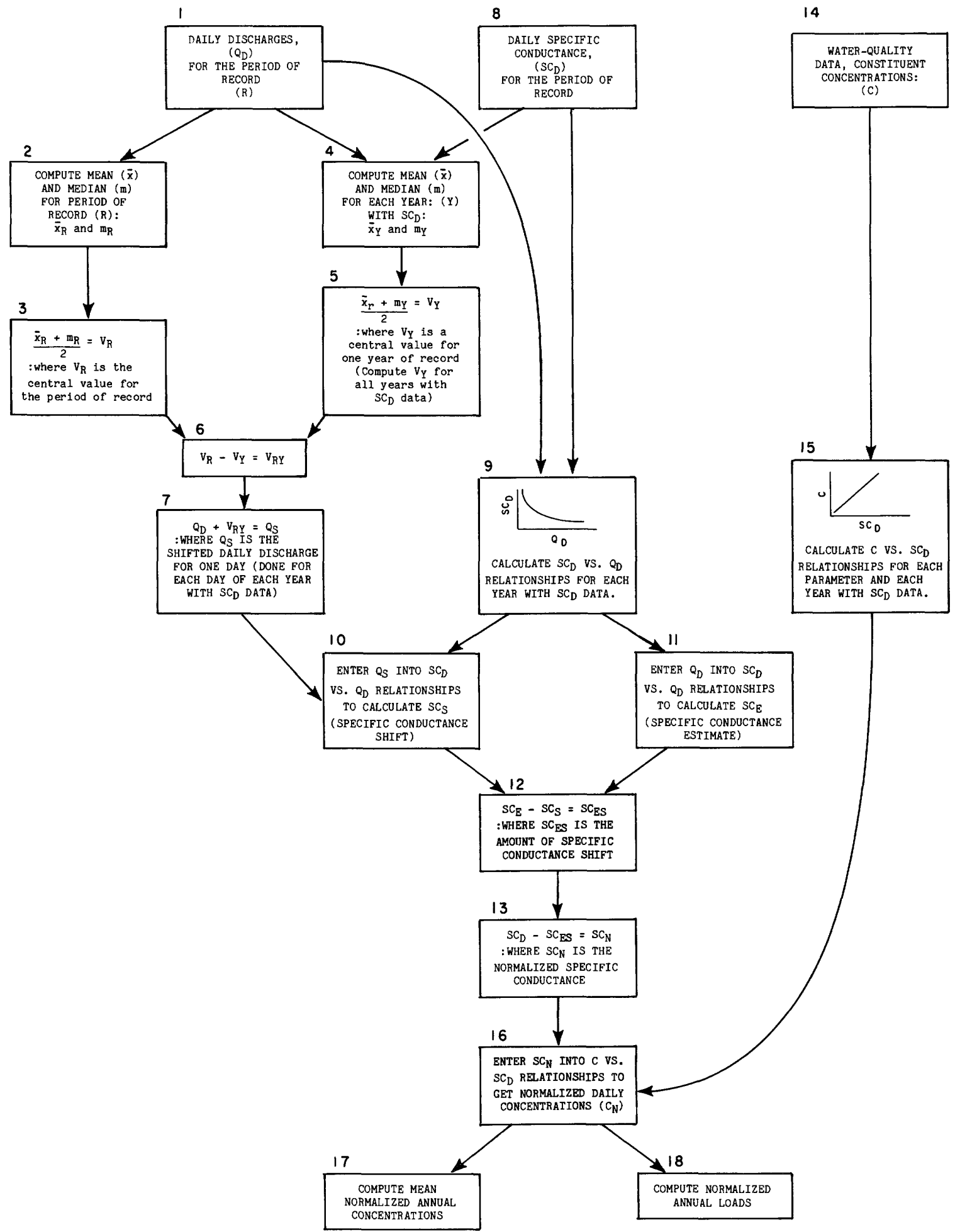

Figure 27.--Flow-diagram of the discharge-normalization technique. 
The same procedure is followed to calculate values for each year ( $Y$ ) that has daily specific conductance record (steps 4 and 5 in fig. 27):

$$
\frac{\mathrm{x}_{\mathrm{Y}}+\mathrm{m}_{\mathrm{Y}}}{2}=\mathrm{V}_{\mathrm{Y}}
$$

where $\mathrm{V}_{\mathrm{Y}}$ is the central discharge value for a single year.

The difference between the central discharge values between the central discharge values for each year $\left(V_{Y}\right)$, and the period of record value $\left(V_{B}\right)$ is the value $\left(\mathrm{V}_{\mathrm{RY}}\right)$ used to normalize the daily discharges $\left(Q_{D}\right.$, steps 6 and 7 in fig. 27);

$$
\begin{aligned}
& \mathrm{V}_{\mathrm{R}}-\mathrm{V}_{\mathrm{Y}}=\mathrm{V}_{\mathrm{RY}} \quad \text { and, } \\
& \mathrm{Q}_{\mathrm{D}}+\mathrm{V}_{\mathrm{RY}}=\mathrm{Q}_{\mathrm{S}}
\end{aligned}
$$

where $Q_{S}$ is the shifted daily discharge for one day. This is done for each day of each year with specific conductance data.

The second step of the normalization procedure is recalculation of daily specific conductances to compensate for the shifted discharges. Using discharge - specific conductance relations, values of specific conductance are estimated from the actual daily discharges $\left(\mathrm{SC}_{\mathrm{E}}\right)$ and from the shifted daily discharges $\left(\mathrm{SC}_{S}\right)$. The differences between these two different calculated specific conductances $\left(\mathrm{SC}_{\mathrm{FS}}\right)$ are in turn subtracted from the observed daily specific conductances ( $\mathrm{SC}_{\mathrm{ES}}^{\mathrm{ES}}$, to produce normalized specific conductance values $\left(\mathrm{SC}_{\mathrm{N}}\right.$, steps $8-13$ in $\left.\mathrm{fig} .27\right)$ :

$$
\begin{aligned}
& S C_{E}-S C_{S}=S C_{E S} \quad \text { and, } \\
& S C_{D}-S C_{E S}=S C_{N}
\end{aligned}
$$

where $\mathrm{SC}_{\mathrm{N}}$ is calculated for each day of each year that has daily specific conductance data. The shifted specific conductance $\left(\mathrm{SC}_{\mathrm{S}}\right)$ is used in equation 6 to compensate for discharge variation. To preserve any variation that is due to pollution, the actual specific conductance $\left(\mathrm{SC}_{\mathrm{D}}\right)$ is used in equation 9 .

Finally, to calculate normalized constituent concentrations, the normalized specific conductances $\left(\mathrm{SC}_{\mathrm{N}}\right.$ ) are entered into constituent concentration specific conductance relations (steps $14-16$ in $\mathrm{fig} .27$ ). The resultant daily constituent concentrations are averaged to produce annual concentrations, or are used with normalized daily discharges to evaluate annual loads. Normalized annual loads or concentrations are regressed with time to produce trend lines. Example results of the discharge-normalization approach for annual potassium 
concentrations are given in figure 28. Increasing trends in potassium concentrations are apparent at both stations. The regression lines shown in figure 28 both have slopes that are significantly different from a slope of zero (twotailed t-test, at a probability level of 0.05$)$. Normalized dissolved-solids loads at Kinston, are compared to total annual loads in figure 29. The actual total loads show a higher degree of irregularity than the normalized loads. This comparison illustrates that the discharge-normalization technique can reduce the apparent data variation that is thought to be caused by fluctuation in discharge. Water-quality trends evaluated by this technique are presented in the Results section of this report.

The discharge-normalization technique employs two sets of regression relations to produce normalized values. Just as in the pollution-load estimation technique, these regression relations may add error to trend analysis. Furthermore, in the normalization analysis for the Neuse River, it was necessary to use estimates of daily specific conductance for the 1964-67 wateryears. These estimates were derived from regressions between daily specificconductance values measured at upstream stations (Neuse River at Fa11s, and Goldsboro) and the instantaneous specific conductance values measured from periodic samples taken at Clayton and Kinston (see Pollution section). In other words, as many as three sets of regression equations were used to produce normalized values for several of the years.

\section{Discharge-frequency-weighting technique}

The third method of evaluating water-quality trends, discharge-frequency weighting, involves a simple process of weighting of the constituent concentrations relative to the discharge frequency distribution for the entire period of record. The discharge-frequency-weighting technique was developed by the author (March, 1978) specifically for this study. A summary flow chart of this approach is presented in figure 30.

The first step in this procedure is to calculate the discharge frequency distribution for the entire period of discharge record for each station (steps 1 and 2 in fig. 30). The instantaneous discharges ssociated with each sample (step 3 in fig. 30) are then matched to the corresponding discharge frequency intervals (step 4 in fig. 30). If two or more samples have associated discharges that fall within the same frequency intervii, then the constituent concentrations for these samples are averaged (step 5 in fig. 30). Next, the area beneath the discharge frequency curve is apportioned to the sample concentrations. To do this, each sample concentration is assigned the area of its matched frequency interval (step 4 in fig. 30) plus the area of adjacent intervals, up to the midpoint between two sample values (step 6 in fig. 30). The resultant apportioning associates each sample concentration with a certain range of flows. The total area of the frequency intervals assigned to each sample value $\left(a_{i}\right)$, or average sample value in the case where several instantaneous discharges are similar, is divided by the total area of all frequency intervals $\left(a_{T}\right)$. The result is an interval weight $\left(W_{i}\right.$; step 7 in $\left.\mathrm{fig} .30\right)$ :

$$
\mathrm{w}_{i}=\mathrm{a}_{\mathrm{i}} / \mathrm{a}_{\mathrm{T}}
$$



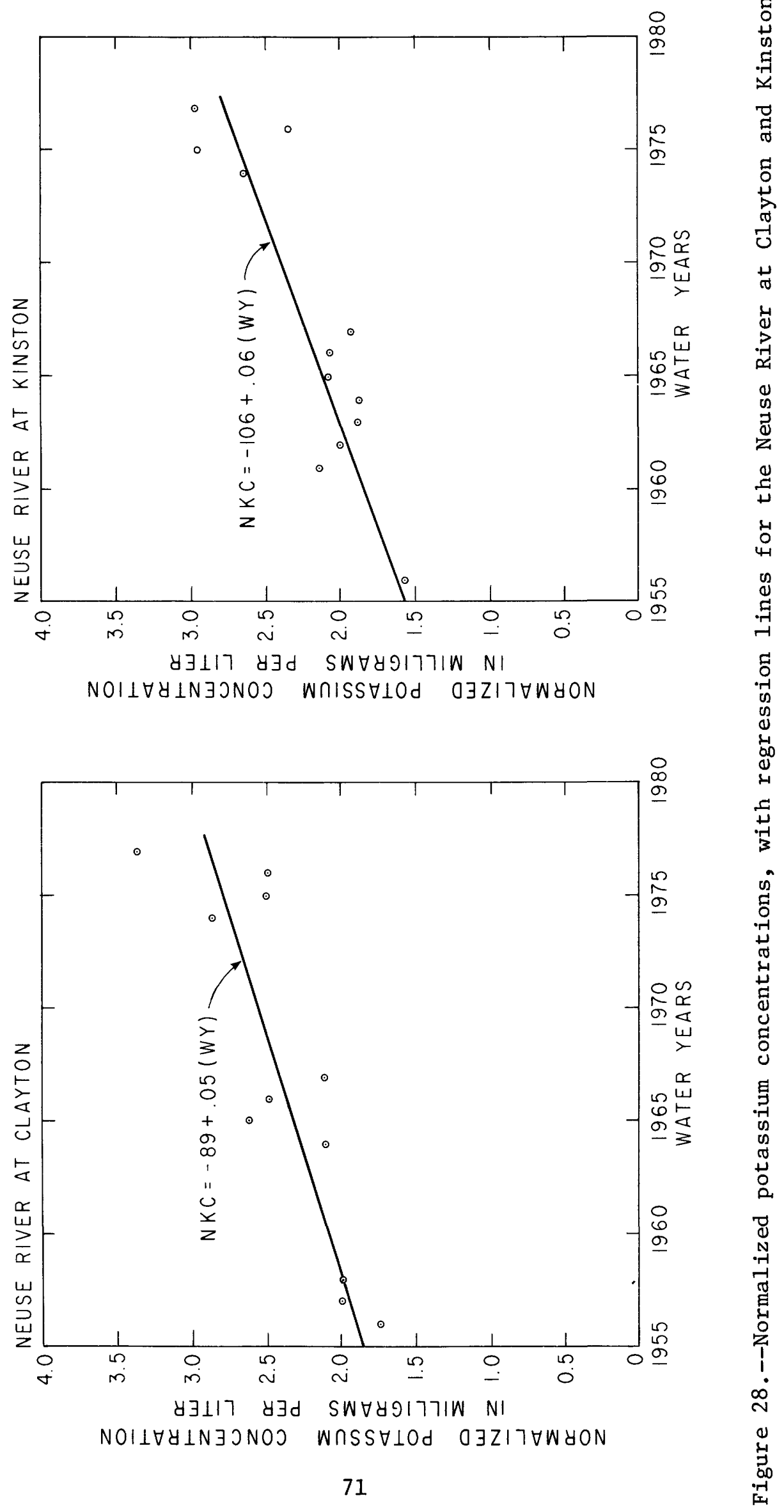


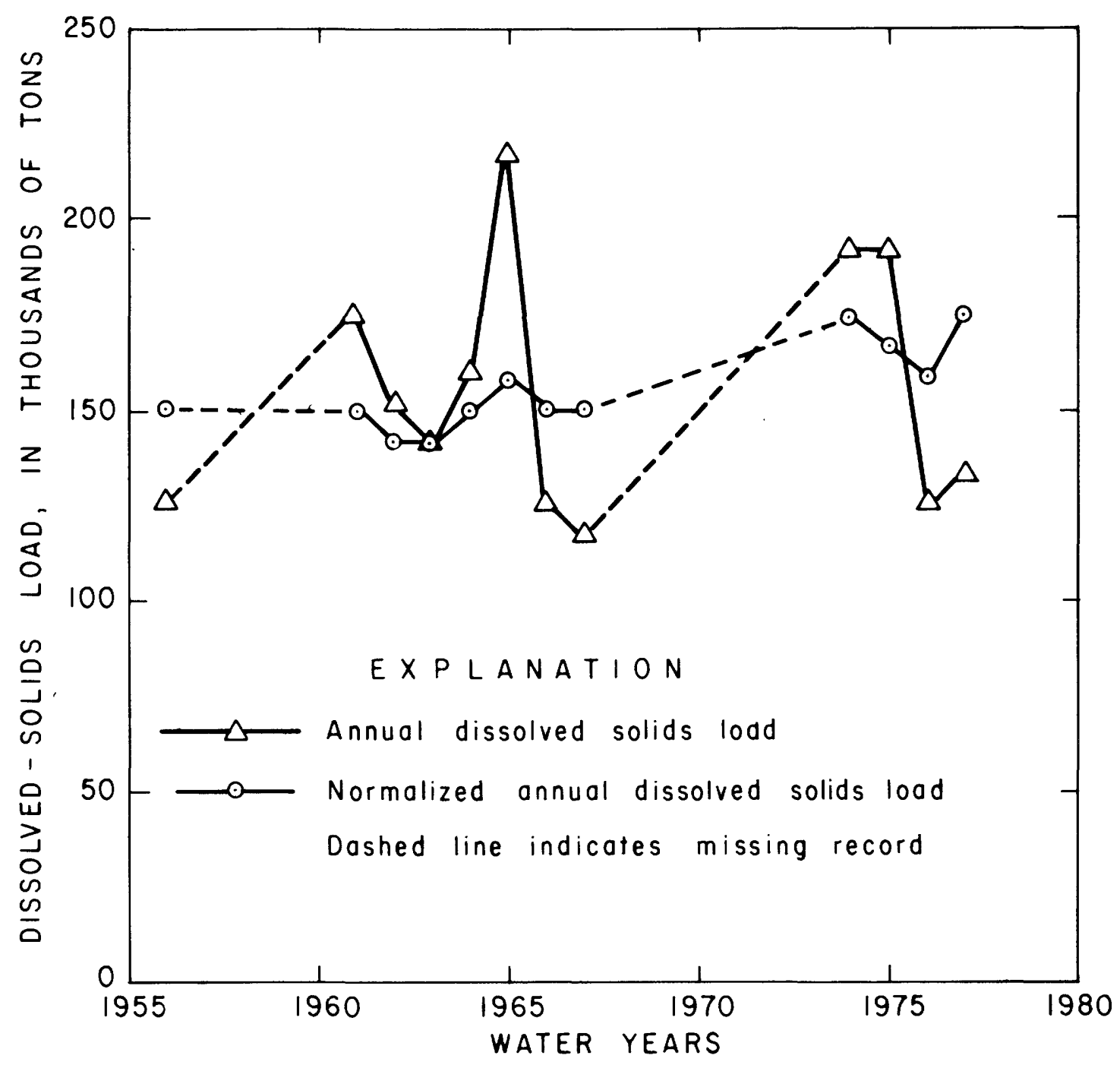

Figure 29.--A comparison of normalized and non-normalized annual dissolved solids loads for the Neuse River at Kinton. 


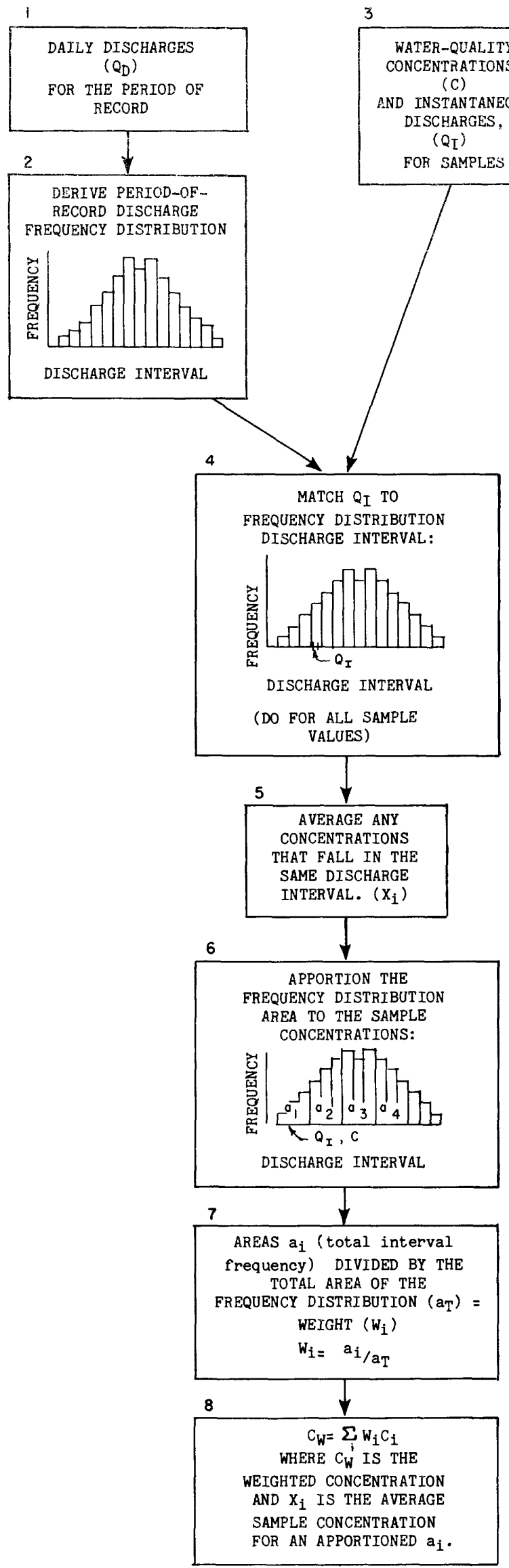

Figure 30.--Flow-diagram of the dischargefrequency-weighting technique used for trend analysis. 
The interval weights (step 7 in fig. 30), are multiplied by the interval concentrations $\left(\mathrm{C}_{i}\right)$ and summed to produce an annual weighted concentration $\left(\mathrm{C}_{\mathrm{w}}\right.$; step 8 in fig. 30).

$$
\mathrm{C}_{\mathrm{w}}=\sum_{i} \mathrm{~W}_{i} \mathrm{C}_{i}
$$

The annual weighted concentrations are then regressed on time to produce trend lines.

Example results of the discharge-frequency-weighting approach for potassium are given in figure 31. Once again, increasing trends in potassium concentrations are apparent at both stations.

One advantage of the discharge-frequency-weighting technique is that it is not restricted in application only to years with complete daily specific conductance records. Therefore, the concentrations shown in the plots of figure 31 are annual averages of weighted constituent analyses.

Discharge-normalization and discharge-frequency-weighting are two approaches to remove the effects of variation in discharge on constituent concentrations. Thus, the two methods attempt to reduce yearly discharges to a constant value, in order to allow year-to-year comparison of water-quality variation from sources other than streamflow changes. One test of whether the two techniques produce values that are independent from discharge is to regress the normalized or weighted values against streamflow. In all cases studied for trend analysis, no significant correlations were found between annual discharges and the results of the normalizing or weighting methods. This indicates that the techniques remove or reduce the effects of discharge to a level below that of other causes of water-quality variation.

The weighted potassium concentrations plotted in figure 31 show scatter similar to the results for potassium of the discharge-normalization technique shown in figure 28. In fact, the results of both methods for many of the water-quality constituents are similar. A regression comparison of the results of the two methods produces several highly correlated $(r=.85)$ relationships. Although there is more overall scatter in the weighted results than in the normalized results, the conclusions that can be drawn from both methods are comparable.

\section{RESULTS}

\section{Long-term trends}

The pollution-load estimation, discharge-normalization, and dischargeweighting methods all produce annual values for water-quality parameters. These values are plotted against time, and regression lines evaluated for these plots represent trends over the period of record. Possible explanations for peaks or dips in values for individual years are of interest, however, such evaluation is beyond the scope of this report. 

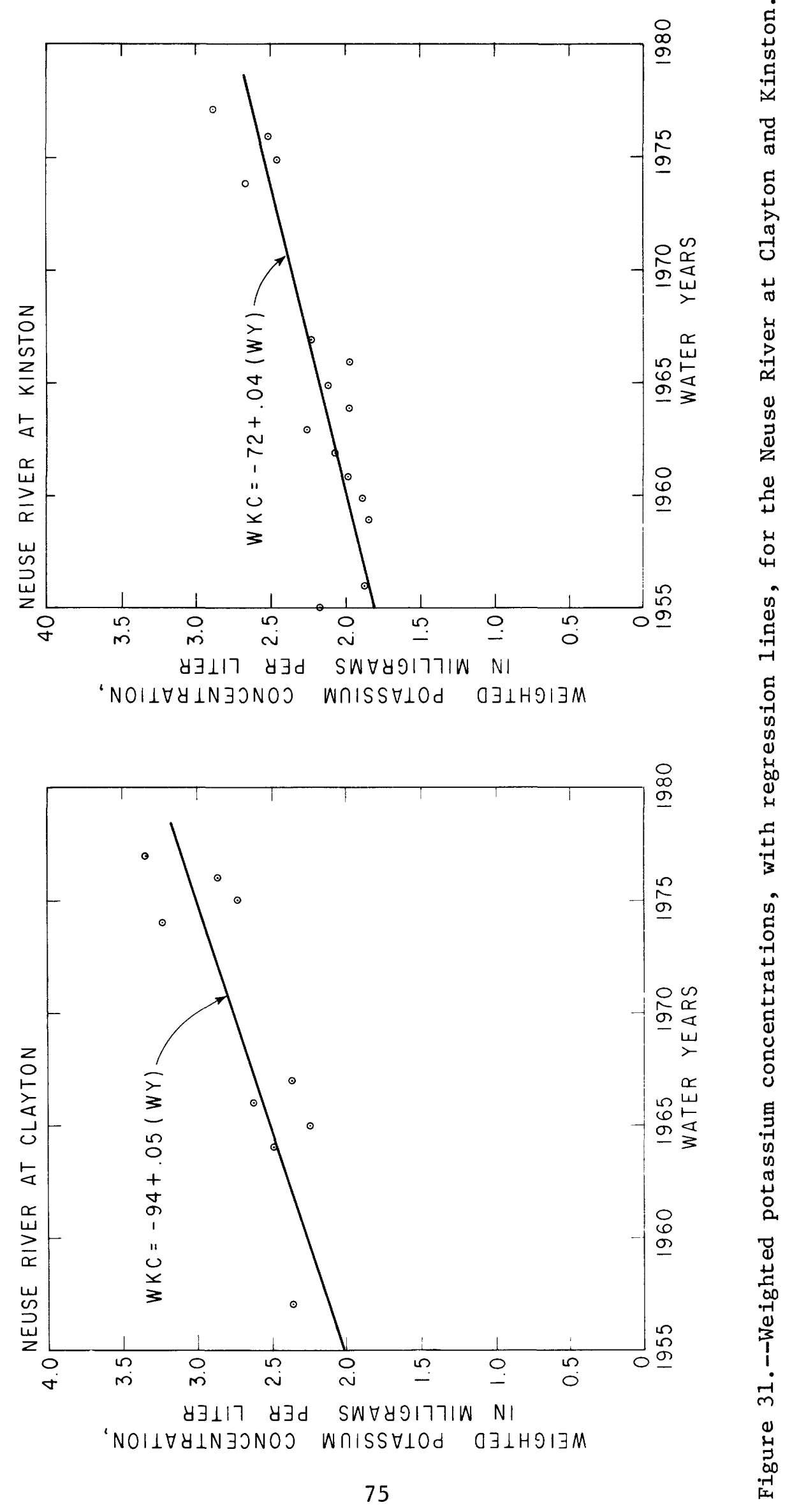
Equations for regression curves fit through the annual values produced by each of the three methods are shown in table 14. Equations with slope terms that are statistically different from a zero slope (two-tailed t-test, probability level $=0.05$ ) are also indicated in table 14 .

Trend lines for dissolved solids produced by the three methods indicate that, although a slight long-term increase in concentration is evident at Kinston, overa11, the change has been slight. Plots of the results of the normalization and weighting techniques (fig. 32) illustrate that the exact nature of the slight change in dissolved solids is unclear.

Trend lines for potassium have already been shown in figures 26,28 and 31. The regression equations for the potassium results are a11 linear, and have positive slopes significantly different from a slope of zero. These results indicate a definite long-term increase in potassium concentration. The normalization and weighting techniques give potassium regression lines that have 1977 concentrations approximately 50 percent greater than 1956 values.

Trend lines for sulfate given by the normalization and weighting techniques are shown in figure 33. As for the potassium results, the sulfate regression equations are linear and have positive slopes significantly different from a slope of zero. These results show a definite long-term increase in sulfate concentration. The discharge normalization technique indicates a 62 percent sulfate concentration increase at Clayton and a 124 percent increase at Kinston. The weighting approach shows a 108 percent increase at Clayton and a 93 percent increase at Kinston.

The results for calcium, chloride, and sodium show no conclusively increasing or decreasing long-term trends. Although subtle long-term changes are shown by each of the methods, no distinct pattern is evident, suggesting that concentrations of these constituents have remained relatively constant since 1956. The lack of change since 1956 is in itself an important result. Current levels of calcium, chloride and sodium in the Neuse are higher, due to pollution, than levels measured at baseline water-quality station sites (see fig. 22). Yet trend analysis shows no conclusive increases or decreases in the loads or concentrations of these constituents in over 20 years. This may indicate that levels of calcium, chlorides and sodium in the Neuse River stabilized before 1956 .

A few other of the regression equations shown on table 14 have statistically significant non-zero slopes. At Kinston normalized calcium concentrations, weighted magnesium concentrations, and weighted specific conductance values have positive slopes, indicating increasing long-term trends. However, these trends were not detected at Clayton. Significantly, the increasing trend in weighted specific conductance reinforces the conclusion that dissolved solids has shown a slight increase over time at this station.

Overal1, increasing trends in potassium and sulfate levels are indicated by all three trend analysis methods for both Clayton and Kinston. An increasing trend for dissolved solids at Kinston is shown by the normalization technique. 


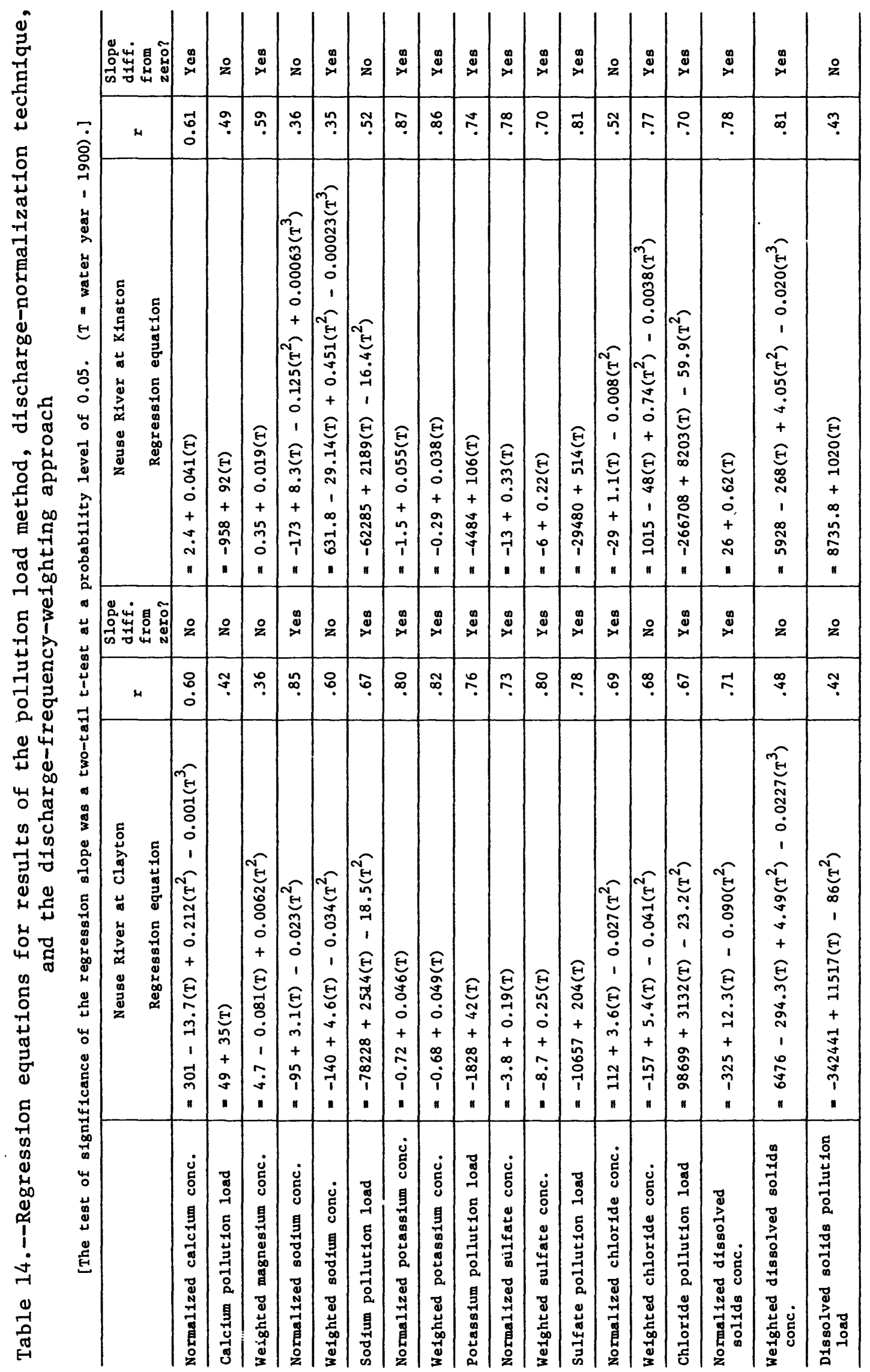




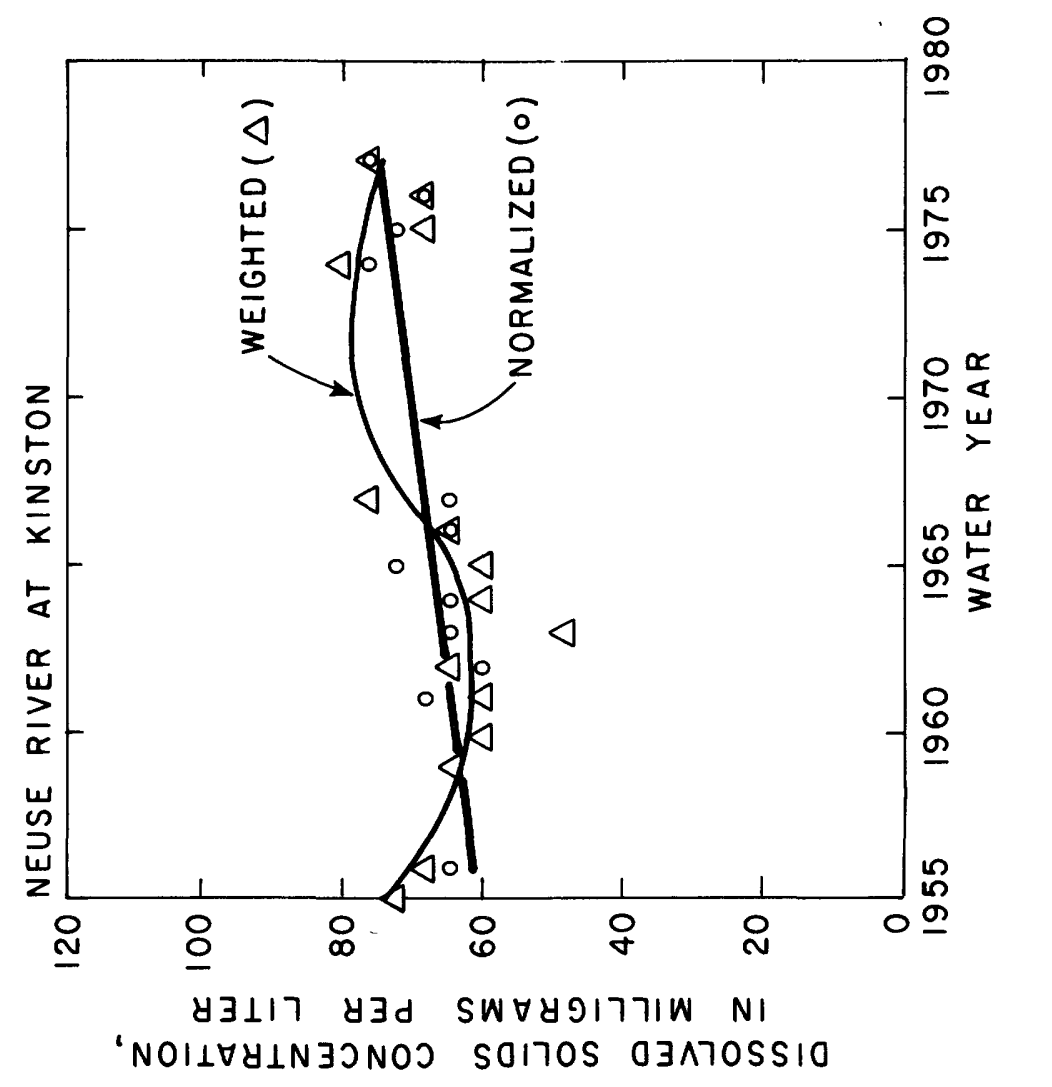

뭄

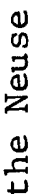

Hु

in

$\stackrel{0}{.}$

I

.

แ)

प्u

告

莒

.

क

出

ซ

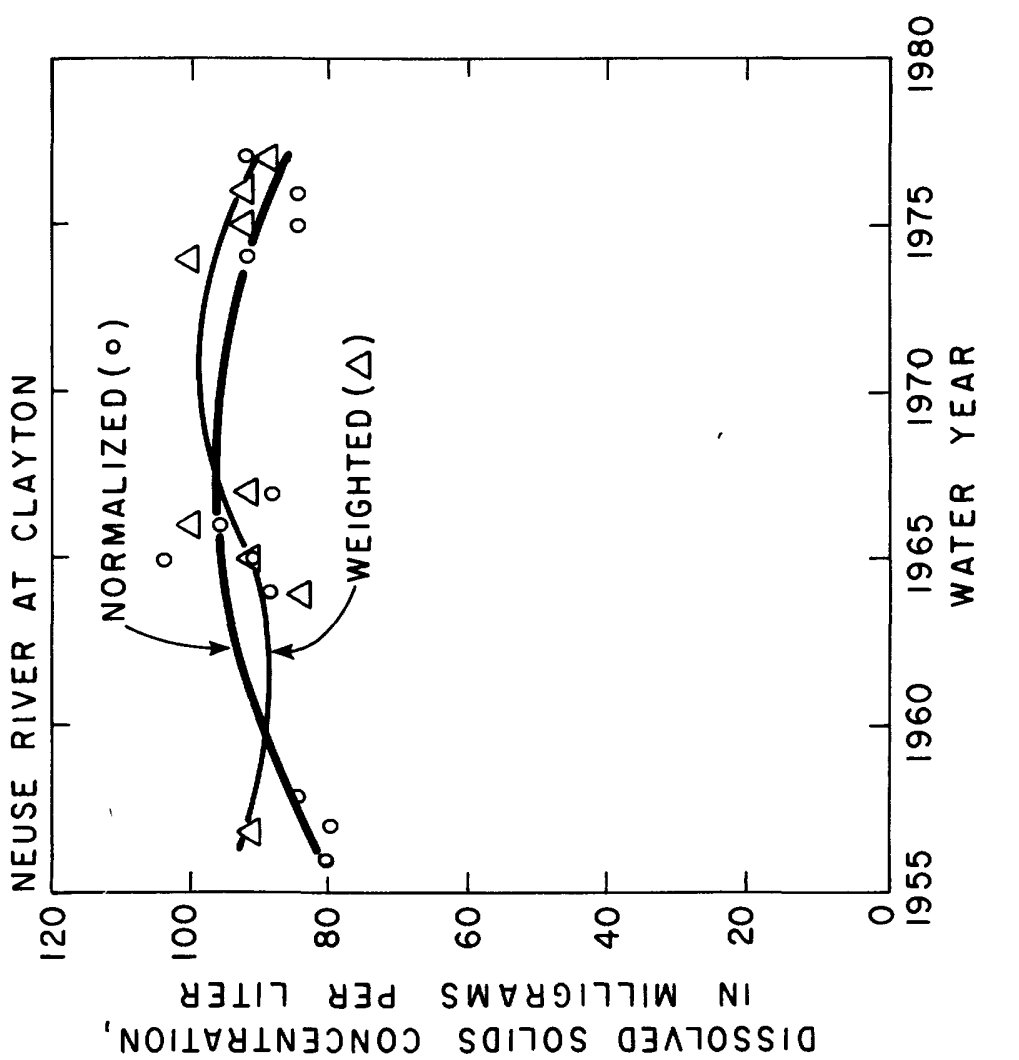

政

战

水

겅

$\frac{1}{0}$

on

त्

$\stackrel{\mathbb{N}}{\stackrel{N}{-1}}$

葛

ธี

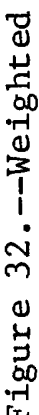



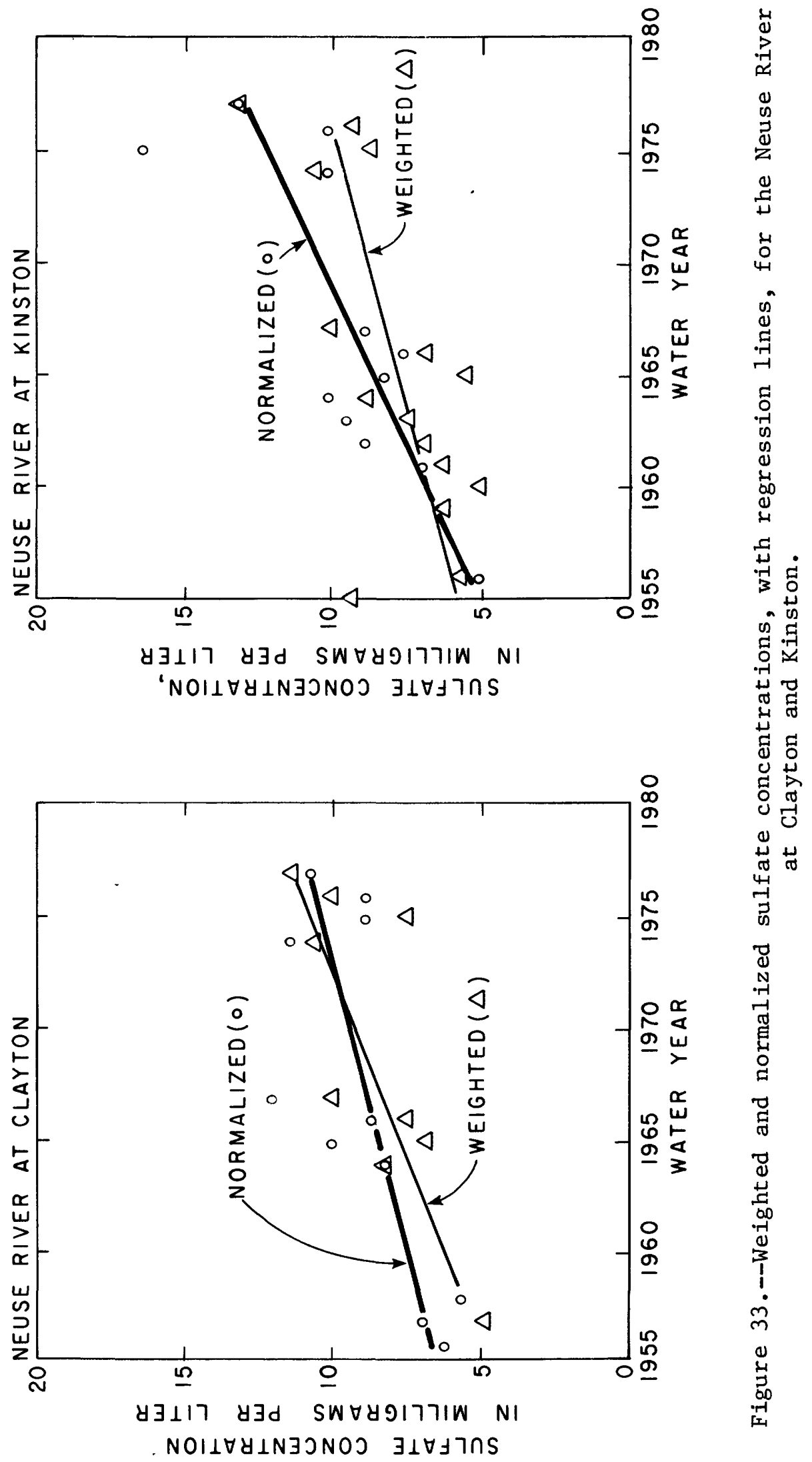
None of the parameters studied show conclusively decreasing trends. However, the relatively stable dissolved-solids trend observed for Clayton implies that some other dissolved components have decreased to offset the increases in potassium and sulfate. It is possible that concentration levels of some of the constituents actually have decreased, but in amounts undetectable by the trendanalysis methods.

The cause of the increase in potassium and sulfate concentration in the Neuse regardless of improved water treatment is unclear, however, the increase serves to illustrate an important point. Modern waste-water treatment plants are rarely designed to treat all of the materials dissolved in waste water. Many dissolved constituents simply pass through the treatment plant, while other constituents may increase in concentration due to the addition of chemical materials used in the treatment process. Although potassium and sulfate are not as relevant to water-quality impact evaluation as constituents such as nutrients or toxic materials, the long-term increase observed for potassium and sulfate are indications of the increasing impact of man on the Neuse River. Other dissolved materials that are not routinely measured in the Neuse and that are unaffected by waste water treatment processes may have had similar longterm increases in concentrations.

One probable cause for the observed increase in sulfate concentration is air pollution. Sulfate is but one of the many forms that sulfur may take when released into the air from the combustion of coal and oil. Oxidation in the atmosphere of inorganic gases including hydrogen sulfide $\left(\mathrm{H}_{2} \mathrm{~S}\right)$, sulfur dioxide $\left(\mathrm{SO}_{2}\right)$ and sulfur trioxide $\left(\mathrm{SO}_{3}\right)$ can produce acids, such as sulfuric acid $\left(\mathrm{H}_{2} \mathrm{SO}_{4}\right)$, which are prime components of acid precipitation (Likens and others, 1979). Although the current evidence of a long-term change in $\mathrm{pH}$ in the Neuse River is inconclusive, it is probable that much of the observed increase in sulfate concentration is a result of acid rain.

\section{Water quality - population relations}

Pollution and population are wed in an intimate relation. Increases in population are inevitably matched with increases in amounts of man-produced wastes. The level of pollution of rivers is largely a function of the amount of waste produced and of how the wastes are disposed. Although simple relations between population and pollution exclude the effect of reduction of pollution by waste-treatment, they provide an approximate means of estimating future water-quality conditions from population projections.

The best relations relating demography to water-quality for the Neuse Basin were obtained using population statistics combined with measures of industrial activity. Population has shown a fairly uniform linear increase in the Neuse River Basin over the past 20 years. But, industrial activity, as measured by manufacturing employment, has not been as uniform as the increase in population. A combined index of the two demographic measures gives a better means of explanation of the wide year-to-year variation seen in the annual values produced by the trend analysis for the Neuse. 
Monthly manufacturing employment estimates for each county are prepared by the North Carolina Employment Security Commission (1978). Manufacturing employment includes food, textile, apparel, lumber, transportation equipment and other industries. Excluded from the manufacturing employment count are: agricultural, construction, trade, utility, service and government employment. The county manufacturing employment values supplied by the Employment Security Commission were weighted by sub-basin population estimates provided by the North Carolina Department of Water and Air Resources (1972). The result of this calculation is a combined index of manufacturing employment and population for the drainage area upstream of each station.

The best regressions between the manufacturing employment-population index and water-quality constituents were for the normalized and weighted potassium and dissolved solids concentrations at kinston. The relation for normalized dissolved solids at Kinston is shown in figure 34 . These relations and all other regressions that passed tests of significance at the 95 percent probability level are listed in table 15.

Overal1, the relations show increasing constituent concentrations with increasing manufacturing employment weighted by population. In fact, even a considerable amount of year-to-year variation is explained by the changes in economic conditions reflected by the index. Given a projected manufacturingpopulation scenario, these relations could be used to approximate future waterquality conditions in the Neuse River.

\section{SUMMARY}

Assessment of Neuse River water quality centered on the identification of water-quality variations in reference to water quality standards, an estimation of the amount of pollution caused by man and an evaluation of long-term trends in concentrations of major dissolved constituents.

Two sampling stations, Neuse River at Clayton (02087500) and Neuse River at Kinston (02089500) have more than 12 years of water-quality data collected during the period from 1955 to 1978. The Clayton station provides information on the urbanized upper fourth of the basin $\left(1,129 \mathrm{mi}^{2}\right)$, and the Kinston station gives data from the predominately rural mid-section of the basin $\left(2,690 \mathrm{mi}^{2}\right)$. The records are discontinuous, containing periods where no samples were collected for several years at a time.

A network of temporary stations located on small rural streams was used to define essentially unpolluted water quality. The constituent concentrations measured in these streams were extrapolated to the Neuse River in order to estimate baseline loads of the major chemical constituents.

The Neuse River is an important water-supply, and a valuable recreational and ecological resource. Fourteen percent of the total population of North Carolina currently live within the boundaries of the basin, and continued growth will make the river increasingly important as a water supply. A major 


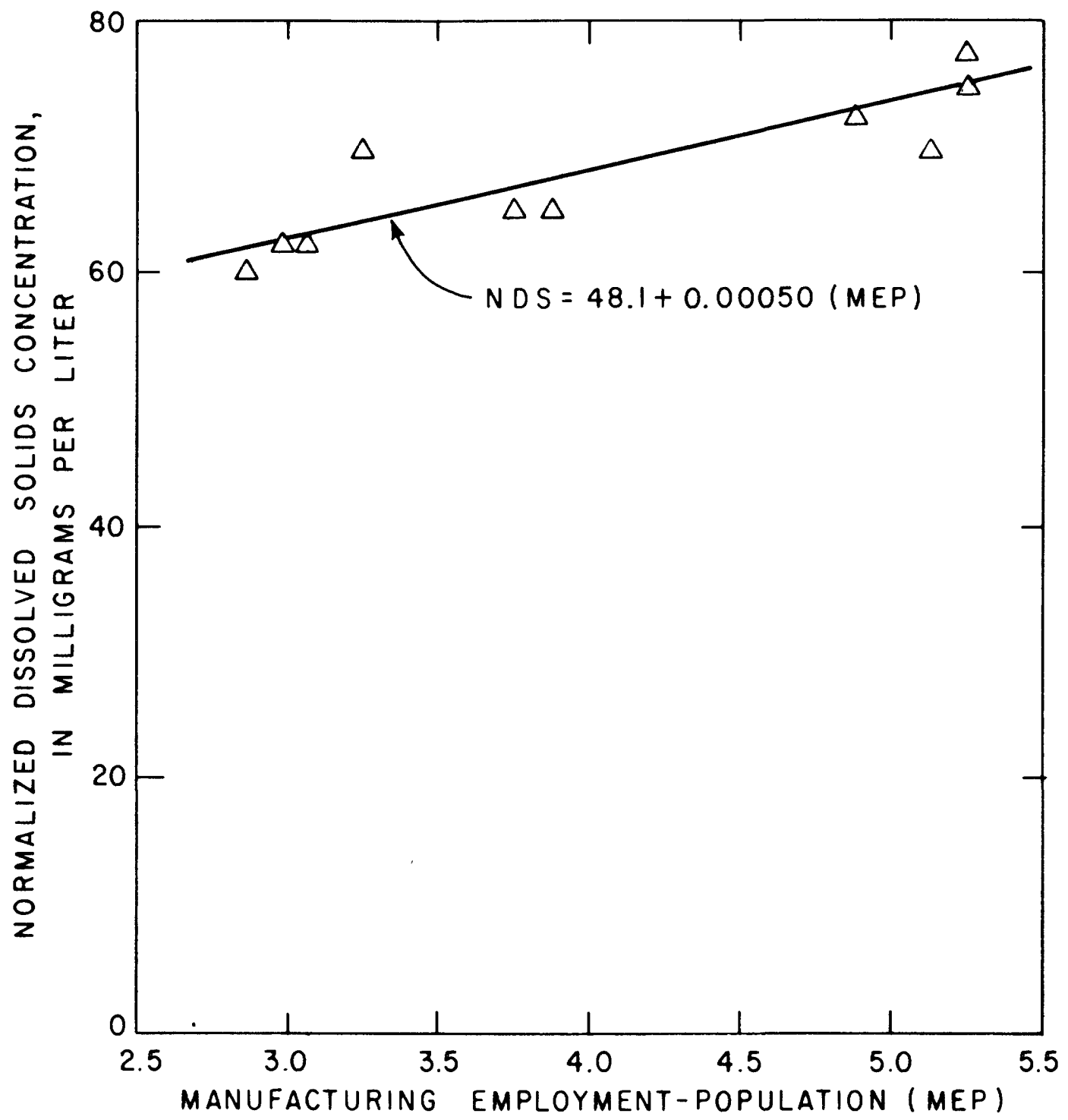

Figure 34.--Normalized dissolved-solids concentration for the Neuse River at Kinston plotted against the manufacturing employment-population index for the river basin upstream of Kinston. 


\begin{tabular}{|c|c|c|c|c|c|c|c|c|c|c|}
\hline 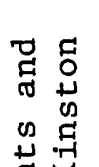 & 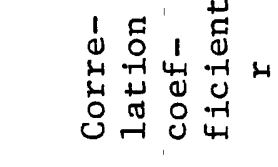 & $\begin{array}{l}\text { nn } \\
\infty \\
\dot{0}\end{array}$ & $\stackrel{m}{r}$ & $\infty$ & 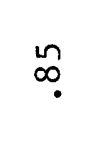 & $\infty$ & $\stackrel{\infty}{?}$. & $\stackrel{\circ}{\wedge}$ & రై & กิ กี \\
\hline 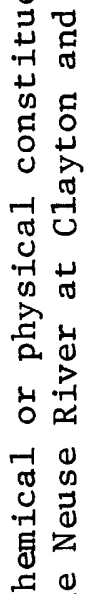 & 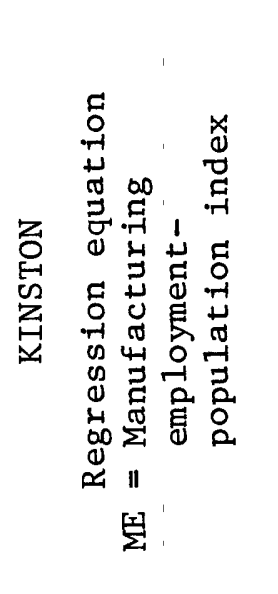 & 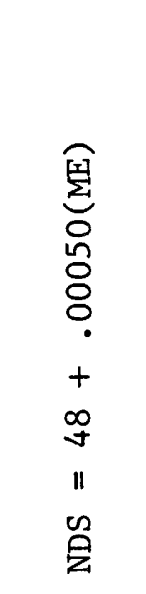 & 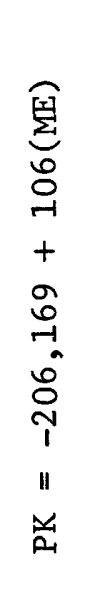 & $\begin{array}{l}\text { 至 } \\
\text { in } \\
0 \\
0 \\
+ \\
0 \\
0 \\
1 \\
11 \\
\text { 总 }\end{array}$ & 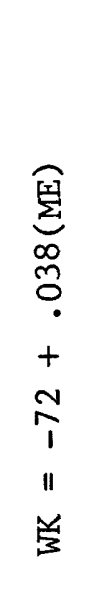 & 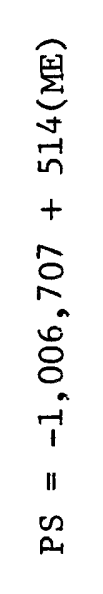 & 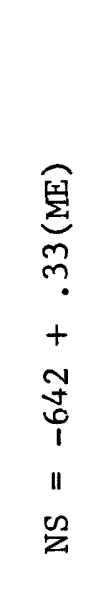 & 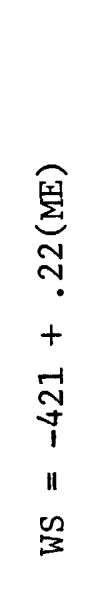 & $\begin{array}{l}\text { 国 } \\
\text { İ } \\
0 \\
0 \\
+ \\
0 \\
1 \\
11 \\
0 \\
z\end{array}$ & 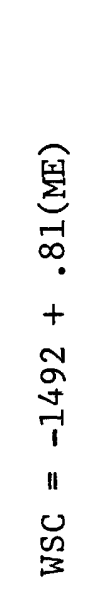 \\
\hline 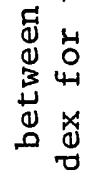 & 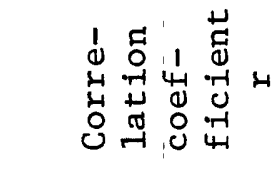 & 1 & $\stackrel{0}{\sim}$ & $\stackrel{0}{\infty}$ & ָ & I & $\stackrel{m}{r}$ & ○. & 1 & 1 \\
\hline 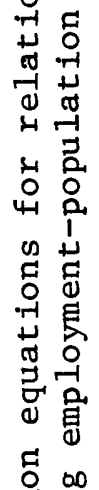 & 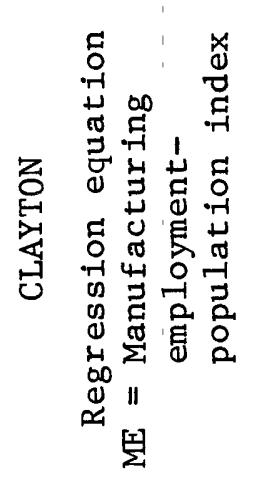 & 1 & 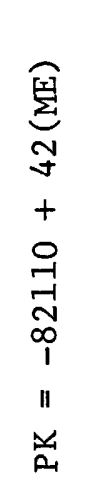 & 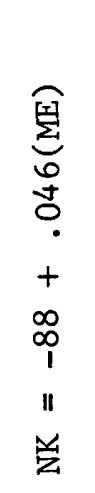 & 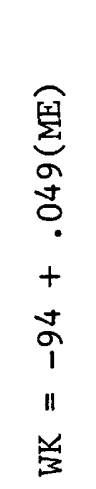 & 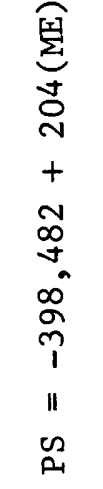 & 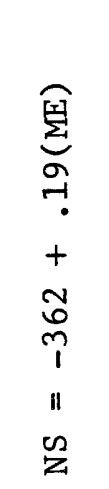 & 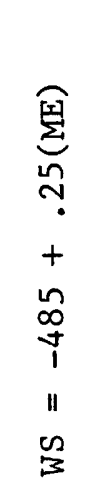 & 1 & 1 \\
\hline 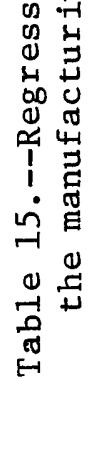 & 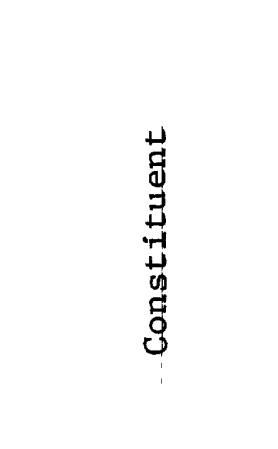 & 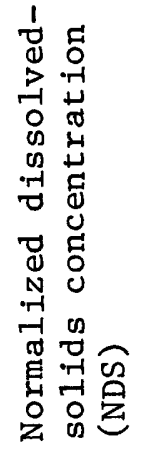 & 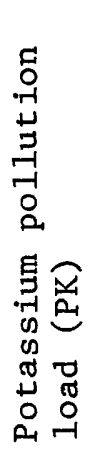 & 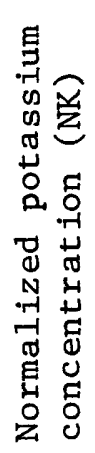 & 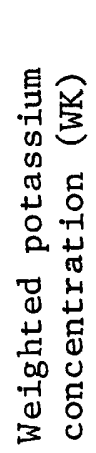 & 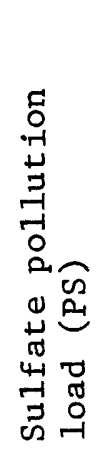 & 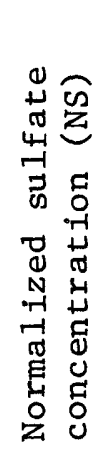 & 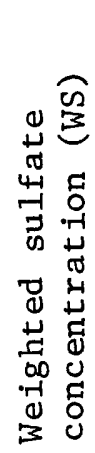 & 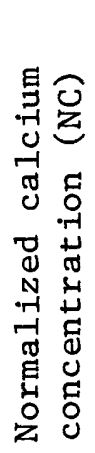 & 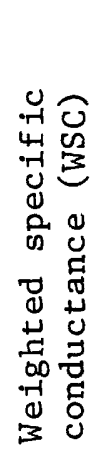 \\
\hline
\end{tabular}


reservoir on the Neuse River, Falls Lake, is currently (1979) under construction. The water quality of the streams feeding this lake will influence the use of the reservoir and its life-time. This reservoir project and other ongoing stream modification will impact the Neuse River environment in future years. Presence of nuisance algal blooms downstream from the dam site is evidence of the current impact of stream modification.

The Neuse also serves an important role in waste disposal. Over 80 percent of the total waste-water discharge upstream from clayton comes from wastewater treatment plants. Over 90 percent of the effluent discharged into the Neuse River segment between Clayton and Kinston comes from municipal wastewater treatment plants.

Over all, the water quality of the Neuse River is satisfactory for most uses. However, dissolved oxygen levels at Clayton are low during the summer, when concentrations are less than $5 \mathrm{mg} / \mathrm{L}$ in 60 percent of the samples. Iron and manganese concentrations, and $\mathrm{pH}$ frequently reach undesirable levels. Approximately 20 percent of the analyses for lead and cadmium are at or above criteria levels for domestic water supply sources (EPA, 1976). Concentrations of selenium in 15 percent of the samples taken at Clayton are above criteria levels. Nutrient levels are generally high enough to allow rich algal growth, presently evident in summer at Kinston and just downstream from the Falls dam site. Currently, eutrophication is not a major concern in the Neuse River, however, future problems may arise in estuary areas or the completed Falls reservoir.

Levels of suspended sediment in the Neuse River are high in comparison to levels observed in pristine streams; however, the impacts of sediment concentrations are difficult to define. The response of suspended sediment concentration to flood discharges at clayton is characterized by a rapid peaking of concentration at the beginning of a flood, followed by a recession. At Kinston, however, changes in discharge are nearly paralleled by changes in sediment concentration. The response observed at Clayton is typical of dischargesediment and discharge-pollutant first flush relations often seen in urbanized areas. This flush effect is due to the rapid storm runoff that occurs in urban areas; nutrient concentrations at Clayton are a good example of this effect.

Biological data indicate some organic pollution of the river. Algal genera often associated with organically enriched water appeared profusely in the Neuse River until 1976. At that time, the Neuse River Waste-water Treatment Plant, an advanced facility designed to treat sewage from the Raleigh metropolitan area, was put into operation. Algal assays taken in more recent years show algae not generally associated with organic enrichment. In addition, TOC concentrations in the Neuse River have decreased significantly since 1976. These results provide evidence of improvement of the water-quality of the Neuse due to activation of this treatment plant.

High total ammonia (median $=0.25 \mathrm{mg} / \mathrm{L}$ as $\mathrm{N}$ ) and moderate $\mathrm{BOD}_{5}$ concentrations (median $=3 \mathrm{mg} / \mathrm{L}$ ) measured at Clayton also characterize the upper Neuse as organically enriched. However, no conclusive reduction in ammonia or 
BOD $_{5}$ is apparent after 1976, the year of the activation of the Raleigh treatment plant. In fact, significant increases in nitrogen and phosphorus concentrations are evident. These increases are probably due to the location of the new treatment plant, which is downstream from the discontinued plants, and closer to the clayton site where water samples were collected.

Bacterial levels are high at both Clayton and Kinston. The recommended fecal coliform levels for bathing (EPA, 1976) are exceeded in 20 percent of the samples at Clayton and 40 percent of the samples at Kinston.

An estimate of pollution in the Neuse was determined by subtracting estimated baseline constituent loads from measured total loads. Only parameters that showed good correlations with specific conductance, and that had a complete historical record were used in this analysis. This method shows approximately 50 percent of the sulfate load at Clayton, 30 percent of the sulfate load at Kinston, 50 percent of the dissolved-solids load for both stations, 70 percent of the sodium and chloride loads at Clayton and 60 percent of the chloride and sodium loads at Kinston, to be pollution caused by man.

A comparison between dissolved-solids loads measured at Clayton and Kinston shows Clayton to have the greatest loads per square mile in all but the most recent years. This correlates well with the observation that the density of population in the area above Clayton is the highest in the entire Neuse basin. A reduction of loads at Clayton and Kinston in recent years may be due to improved wastewater treatment provided by the Neuse River wastewater treatment plant.

Annual pollution-load estimates give rough measures of trends in water quality. However, these load estimates are the end result of several steps of data manipulation that may introduce some uncertainty. Furthermore, the annual loads are highly dependent on annual discharge. Clearly, extraction of the effect of discharge on constituent loads is necessary in order to define trends.

Two different data transformation methods made it possible to identify trends in water-quality constituent concentrations. These transformations recomputed concentrations as if the samples were collected at equal discharges over the period of record.

Both methods indicate that there has been a slight change in the chemistry of the Neuse River since 1956. Although long-term data are not available for constituents that are more relevant to water-quality impact analysis such as nutrients or toxic chemicals, increases of over 50 percent since 1956 in concentrations of sulfate and potassium are indicated. This is probably because modern waste-water treatment plants are not often designed to treat all of the materials dissolved in waste water; and sulfate and potassium, for example, simply pass through the treatment works and are released into the stream. Therefore the increasing quantity of sulfate and potassium over the years is a good indication of the increasing impact that man has had on the water quality of the Neuse. The increase in sulfate especially, is probably largely a result 
of acid precipitation, which is a growing problem in large areas of the United States.

The relation between pollutant levels and an index of demographic change provides a rough means of predicting future water quality. Regressions of dissolved-solids and potassium levels of the Neuse River at Kinston with basin maunfacturing employment and basin population are examples of these relations.

Demographic changes in the Neuse River basin have probably resulted in modifications of the chemistry of the Neuse that have not been detected in this limited study. Increases in population, or industrial and urban development may have resulted in pollution of the Neuse River by materials other than those emphasized in this report. A growing environmental awareness and improved laboratory techniques have promoted accurate identification of a wide variety of important trace materials in water, some of which that are collected now on a routine basis. These data will be invaluable in future assessments of the water quality of the Neuse River. 


\section{REFERENCES CITED}

American Public Works Association, 1969, Water pollution aspects of urban runoff: Federal Water Pollution Control Administration, WP-20-15, 272 p.

Billingsley, G. A., Fish, R. E., and Schipf, R. G., 1957, Water resources of the Neuse River basin, North Carolina: U.S. Geological Survey Water Supply Paper 1414, $89 \mathrm{p}$.

Fish, F. F., 1968, A catalog of the inland fishing waters in North Carolina: North Carolina Wildlife Resources Commission, Project F-14-R, 312 p.

Gambell, A. W., and Fisher, D. W., 1966, Chemical composition of rainfall, eastern North Carolina and southeastern Virginia: U.S. Geological Survey Water-Supply Paper 1535-K, 41 p.

Geldriech, E. E., 1966, Sanitary significance of fecal coliforms in the environment: Federal Water Pollution Control Administration WP-20-3, 122 p.

Hines, W. G., McKenzie, S. W., Rickert, D. A., and Rinella, F. A., 1977, Dissolved-oxygen regimen of the Willamette River, Oregon, under conditions of basinwide secondary treatment: U.S. Geological Survey Circular 715-1, $152 \mathrm{p}$.

Hobbie, J. E., and Smith, N. W., 1975, Nutrients in the Neuse River estuary: University of North Carolina Sea Grant Publication UNC-SG-75-21, 183 p.

Likens, G. E., Wright, R. F., Galloway, J. N., and Butler, T. J., Acid rain: Scientific American, October 1979, v. 241, no. 4, p. 43-51.

National Technical Advisory Committee, 1968, Water-quality criteria, a report of the National Technical Advisory Committee to the Secretary of the Interior: U.S. Government Printing Office, Washington, D. C.

Nemerow, N. L., 1974, Scientific stream pollution analysis: McGraw Hill Book Company, New York, 358 p.

North Carolina Department of Water and Air Resources, 1972, Basin population: Water-Resources Planning Section.

North Carolina Department of Natural and Economic Resources, 1975a, Neuse-White Oak River basin - Vol. I (Draft): Division of Resources Planning and Evaluation, Water-Resources Planning Section.

$1975 \mathrm{~b}$, Water quality management plan Neuse River basin: Division of Environmental Management.

1976, Civil works water resources development program, $30 \mathrm{p}$.

North Carolina Department of Natural Resources and Community Development, 1979, Water quality management plan, executive summary: Division of Environmental Management, $25 \mathrm{p}$.

North Carolina Employment Security Commission, 1978, North Carolina labor force estimates 1977 - by county, area, and state: Bureau of Employment Security Research, 274 p.

Putnam, A. L., and Lindskov, K. L., (1973), Water resources of the Upper Neuse River Basin, North Carolina, U.S. Geological Survey Water Resources Investigations $12-75,68 \mathrm{p}$.

Rorabaugh, M. I., 1964, Estimating changes in bank storage and ground-water contribution to streamflow: International Association of Scientific Hydrology Publication 63, p. 432-441.

Simmons, C. E., and Heath, R. C., 1979, Water-quality characteristics of forested and rural basins in North Carolina: U.S. Geological Survey Water Resources Investigations 79-108. 
Slack, K. V., 1974, Drift organisms in streams: U.S. Geological Survey Quality of Water Branch Technical Memorandum No. 78.04 .

Stiff, H. A., Jr., 1951, The interpretation of chemical water analysis by means of patterns: Journal of Petroleum Technology, v. 3, no. 10, p. 15-17.

Todd, D. K., 1970, The Water enclyclopedia: Water Information Center, 559 p.

Triangle J Council of Governments, 1976, 208 Pollution source analysis: TJCOG, P.0. Box 12276, Research Triangle Park, N.C.

1977, 208 Areawide water quality management plan: TJCOG, P.0. Box 12276, Research Triangle Park, N. C.

U.S. Army Corps of Engineers, 1964, Neuse River basin, North Carolina U.S. Army Engineer District, Wilmington. 1973, Draft environmental statement, Falls Lake, Neuse River basin, North Carolina: U.S. Army Engineer District, Wilmington. 1977, Water resources development by the U.S. Army Corps of Engineers in North Carolina: U.S. Army Engineer Division, South Atlantic, p. 73-80.

U.S. Department of Commerce, 1971, Number of inhabitants, North Carolina: Bureau of the Census, PS(1)-A35 N.C., 44 p.

U.S. Environmental Protection Agency, 1976, Quality criteria for water: U.S. Government Printing Office, Washington, D. C., 256 p.

Weiss, C. M., and Kuenzler, E. J., 1976, The trophic state of North Carolina lakes: North Carolina Water Resources Research Institute report No. 119, $224 \mathrm{p}$.

Weiss, C. M., Francisco, D. E., and Lenat, D. R., 1973, Preimpoundment studies Falls project - water quality characteristics, in U.S. Army Corps of Engineers draft environmental statement, Falls Lake, Neuse River basin, North Carolina, appendix I: U.S. Army Engineer District, Wilmington, N.C. Wershaw, R. L., 1976, Organic chemistry of lead in natural water systems, in Lead in the environment: U.S. Geological Survey Professional Paper $9 \overline{57}$, p. 13-16.

Wilder, H. B., and Simmons, C. E., 1978, Program for evaluating stream quality in North Carolina: U.S. Geological Survey Circular 764, 16 p. 